Supporting Information

\title{
Artificial Chloride-Selective Channel: Shape and Function Mimic of the CIC Channel Selective Pore
}

\author{
Wen-Long Huang, ${ }^{a, b}$ Xu-Dong Wang, ${ }^{\text {a,b }}$ Yu-Fei Ao, ${ }^{a}$ Qi-Qiang Wang, a,b,* \\ and De-Xian Wang ${ }^{\mathrm{a}, \mathrm{b}, *}$ \\ ${ }^{a}$ Beijing National Laboratory for Molecular Sciences, CAS Key Laboratory of \\ Molecular Recognition and Function, Institute of Chemistry, CAS, Beijing, 100190, \\ China. \\ ${ }^{b}$ University of Chinese Academy of Sciences, Beijing 100049, China. \\ E-mail: qiqiangw@iccas.ac.cn, dxwang@iccas.ac.cn
}




\section{Contents}

$\begin{array}{ll}\text { 1. General information } & \text { S2 }\end{array}$

2. Synthesis procedure S3

3. NMR titrations $\quad$ S8

$\begin{array}{ll}\text { 4. Ion transport activity and DPPC assays } & \text { S13 }\end{array}$

$\begin{array}{lr}\text { 5. Planar lipid bilayer experiments } & \text { S19 }\end{array}$

6. Ion selectivity study by planar lipid bilayer experiments $\quad$ S30

$\begin{array}{ll}\text { 7. Calculation } & \text { S38 }\end{array}$

8. Copies of ${ }^{1} \mathrm{H}$ and ${ }^{13} \mathrm{C}$ NMR spectra $\quad$ S46

9. References $\quad$ S51 


\section{General Information}

Reagents for synthesis and analysis were purchased from J\&K or Sigma-Aldrich. A Mini-Extruder used for vesicle preparation, egg yolk phosphatidylcholine (EYPC), DPPC and 1, 2-diphytanoyl-sn-glycero-3-phosphocholine (DPhP) were purchased from Avanti Polar Lipids. ${ }^{1} \mathrm{H}$ and ${ }^{13} \mathrm{C}$ NMR spectra were recorded on Bruker 400 or $500 \mathrm{MHz}$ NMR spectrometer. Chemical shifts are reported in ppm and referenced to tetramethylsilane (TMS) or the residual solvent resonance. Abbreviations are used in the description of NMR data as follows: chemical shift $(\delta, \mathrm{ppm})$, multiplicity $(\mathrm{s}=$ singlet, $\mathrm{d}=$ doublet, $\mathrm{t}=$ triplet, $\mathrm{q}=$ quartet, quint $=$ quintet, $\mathrm{m}=$ multiplet ), coupling constant $(J, \mathrm{~Hz})$. Melting points are uncorrected. Infrared spectra were recorded on Nicolet-6700 FT-IR spectrometer. Mass spectra were obtained on Bruker APEX-2 (HRMS). Elemental analysis was recorded on Thermo Quest CE Instruments flash EA 1112 analyser. All anhydrous solvents were dried according to standard procedures prior to use. All other major chemicals were obtained from commercial sources and used without further purification. 


\section{Synthesis procedure}

\section{Synthesis of 5}

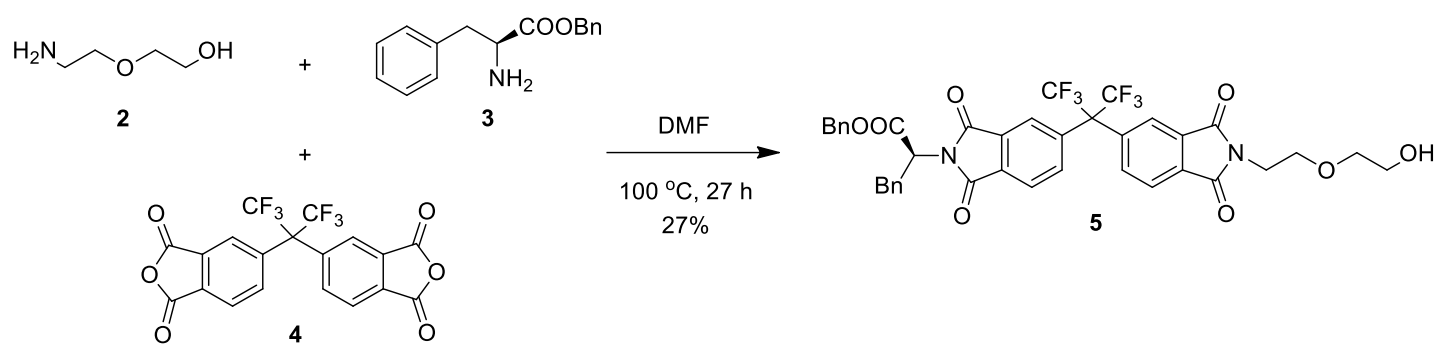

$\mathbf{3}^{[\mathrm{S} 1]}(5.11 \mathrm{~g}, 20 \mathrm{mmol}), 4(17.77 \mathrm{~g}, 40 \mathrm{mmol})$ and dried DMF $(20 \mathrm{~mL})$ were mixed in a flask. The mixture was heated to $100{ }^{\circ} \mathrm{C}$ for $3 \mathrm{~h}$. Then 2-(2-aminoethoxy)ethanol $2(6.31 \mathrm{~g}, 60 \mathrm{mmol})$ was added, and the mixture was stirred at $100{ }^{\circ} \mathrm{C}$ for $24 \mathrm{~h}$. After cooling to room temperature, DMF was removed by rotary evaporation. The residue dissolved in $100 \mathrm{~mL}$ ethyl acetate and $100 \mathrm{~mL}$ water, and the two phases were separated. The aqueous phase was extracted with ethyl acetate $(2 \times$ $50 \mathrm{~mL})$. The combined organic phase was washed with brine $(2 \times 100 \mathrm{~mL})$ and then dried with anhydrous sodium sulfate. After filtration and removal of organic solvent, the residues were chromatographed on a silica gel column (100-200 mesh) with a mixture of dichloromethane and acetone $(35: 1, \mathrm{v} / \mathrm{v})$ as an eluent to give pure compound 5 as a white solid (4.30 g, 27\%). 5: m.p. 77-78 ${ }^{\circ} \mathrm{C} ;{ }^{1} \mathrm{H} \mathrm{NMR}\left(\mathrm{CDCl}_{3}, 500\right.$ MHz) $\delta 7.91(\mathrm{~d}, J=8.0 \mathrm{~Hz}, 1 \mathrm{H}), 7.87-7.79(\mathrm{~m}, 2 \mathrm{H}), 7.77(\mathrm{~s}, 1 \mathrm{H}), 7.70(\mathrm{dd}, J=12.9$, 8.1 Hz, 2H), 7.36-7.29 (m, 5H), 7.24-7.19 (m, 2H), 7.19-7.13 (m, 3H), 5.27-5.20 (m, $3 \mathrm{H}), 3.94(\mathrm{t}, J=5.4 \mathrm{~Hz}, 2 \mathrm{H}), 3.76(\mathrm{t}, J=5.4 \mathrm{~Hz}, 2 \mathrm{H}), 3.73-3.67(\mathrm{~m}, 2 \mathrm{H}), 3.67-3.53$ $(\mathrm{m}, 4 \mathrm{H}), 2.04(\mathrm{~s}, 1 \mathrm{H}) ;{ }^{13} \mathrm{C}\left\{{ }^{1} \mathrm{H}\right\} \mathrm{NMR}\left(\mathrm{CDCl}_{3}, 125 \mathrm{MHz}\right) \delta 168.5,167.3,167.2,166.5$, $166.3,139.0,138.8,136.5,135.9,135.8,135.2,133.0,132.7,132.6,132.2,128.9$, $128.8,128.7,128.6,128.4,127.2,125.1,124.9,123.9,123.8,123.4$ (q, $J=286.2 \mathrm{~Hz})$, 72.3, 68.4, 68.0, 65.2 (quint, $J=26.2 \mathrm{~Hz}$ ), 61.9, 54.1, 38.1, 34.7; IR (KBr) v 3479, 3078, 2920, 2850, 1779, 1717, 1631, 1497, 1386, $1255 \mathrm{~cm}^{-1}$; HRMS $\left(\mathrm{ESI}^{+}\right): m / z$ calc. for $[\mathrm{M}+\mathrm{Na}]^{+}\left(\mathrm{C}_{39} \mathrm{H}_{30} \mathrm{O}_{8} \mathrm{~N}_{2} \mathrm{~F}_{6} \mathrm{Na}^{+}\right) 791.1799$, found 791.1793. 


\section{Synthesis of 8}
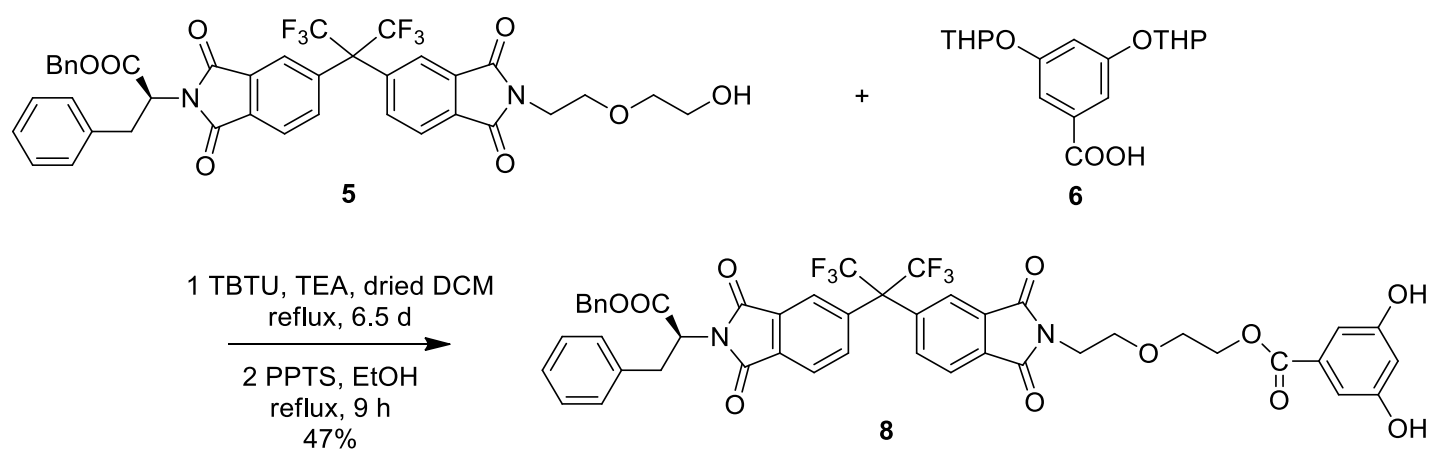

$\mathbf{6}^{[\mathrm{S} 2]}(1.29 \mathrm{~g}, 4 \mathrm{mmol})$, TBTU $(1.57 \mathrm{~g}, 4.8 \mathrm{mmol})$, TEA $(809 \mathrm{mg}, 8 \mathrm{mmol})$ and dried DCM (200 mL) were mixed in a flask. After 15 mins, 5 (3.07 g, 4 mmol) was added. The mixture was heated to reflux for $6.5 \mathrm{~d}$. After cooling to room temperature, DCM was removed by rotary evaporation. The residue dissolved in ethyl acetate and then washed with water and brine two times respectively. After removal of organic solvent, EtOH (300 mL) and PPTS $(410 \mathrm{mg}, 1.6 \mathrm{mmol})$ were added to the residue. The mixture was heated to reflux for $9 \mathrm{~h}$. After cooling to room temperature, EtOH was removed by rotary evaporation. The residue dissolved in ethyl acetate, washed with water and brine two times respectively, and then dried with anhydrous sodium sulfate. After filtration and removal of organic solvent, the residue was chromatographed on a silica gel column (100-200 mesh) with a mixture of dichloromethane and methanol $(120: 1, \mathrm{v} / \mathrm{v})$ as an eluent to give pure compound 8 as a white solid (1.73 g, 47\%). 8: m.p. $98-99{ }^{\circ} \mathrm{C} ;{ }^{1} \mathrm{H}$ NMR $\left(\mathrm{CDCl}_{3}, 500 \mathrm{MHz}\right) \delta 7.82(\mathrm{~d}, J$ $=8.0 \mathrm{~Hz}, 1 \mathrm{H}), 7.79-7.71(\mathrm{~m}, 3 \mathrm{H}), 7.71-7.60(\mathrm{~m}, 2 \mathrm{H}), 7.40-7.28(\mathrm{~m}, 5 \mathrm{H}), 7.24-7.08(\mathrm{~m}$, 5H), $7.00(\mathrm{~d}, J=2.3 \mathrm{~Hz}, 2 \mathrm{H}), 6.55(\mathrm{br}, 2 \mathrm{H}), 6.38(\mathrm{t}, J=2.3 \mathrm{~Hz}, 1 \mathrm{H}), 5.34-5.17(\mathrm{~m}$, $3 \mathrm{H}), 4.36(\mathrm{t}, J=5.0 \mathrm{~Hz}, 2 \mathrm{H}), 3.96(\mathrm{t}, J=5.5 \mathrm{~Hz}, 2 \mathrm{H}), 3.86(\mathrm{t}, J=5.4 \mathrm{~Hz}, 2 \mathrm{H}), 3.80(\mathrm{t}$, $J=4.5 \mathrm{~Hz}, 2 \mathrm{H}), 3.69-3.49(\mathrm{~m}, 2 \mathrm{H}) ;{ }^{13} \mathrm{C}\left\{{ }^{1} \mathrm{H}\right\} \mathrm{NMR}\left(\mathrm{CDCl}_{3}, 125 \mathrm{MHz}\right) \delta 168.9,167.8$, $167.5,167.0,166.5,166.2,157.3,138.9,138.8,136.4,136.0,135.8,135.0,132.7$, $132.4,132.0,128.9,128.8,128.78,128.7,128.4,127.2,125.1,125.0,124.0,123.9$, $123.4(\mathrm{q}, J=286.2 \mathrm{~Hz}), 109.0,107.6,68.7,68.23,68.17,65.2$ (quint, $J=26.2 \mathrm{~Hz}$ ), 64.2, 54.2, 38.2, 34.7; IR (KBr) v 3412, 3078, 2947, 2872, 1779, 1717, 1602, 1454, 
1386, 1255, $1212 \mathrm{~cm}^{-1}$; HRMS (APCI'): $\mathrm{m} / z$ calc. for $[\mathrm{M}-\mathrm{H}]^{-}\left(\mathrm{C}_{46} \mathrm{H}_{33} \mathrm{O}_{11} \mathrm{~N}_{2} \mathrm{~F}_{6}{ }^{-}\right)$ 903.1994, found 903.2019.

\section{Synthesis of 9}

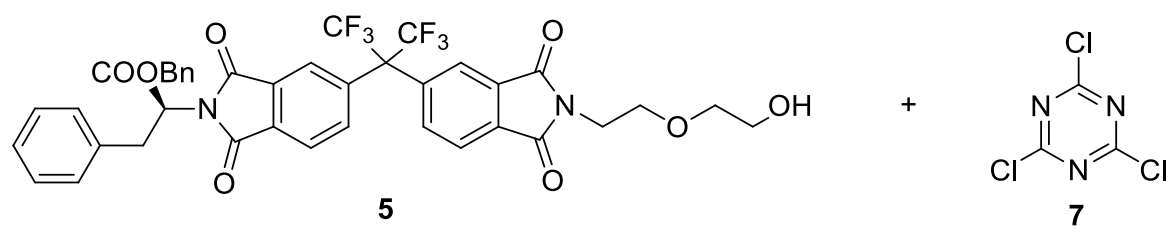

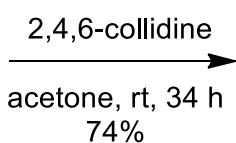

$74 \%$

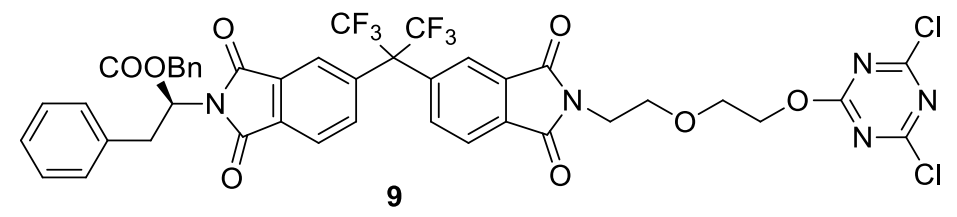

At room temperature, cyanuric chloride $7(1.11 \mathrm{~g}, 6 \mathrm{mmol})$ and acetone $(40 \mathrm{~mL})$ were mixed in a two-neck flask. The solution of 5 (3.07 g, $4 \mathrm{mmol})$ and 2,4,6-collidine (594 $\mathrm{mg}, 4.8 \mathrm{mmol})$ in acetone $(40 \mathrm{~mL})$ was then added dropwise within $2 \mathrm{~h}$. The resulting mixture was stirred for $32 \mathrm{~h}$ at room temperature. Acetone was removed by rotary evaporation. The residue dissolved in ethyl acetate $(200 \mathrm{~mL})$ and washed with water and brine two times respectively, and then dried with anhydrous sodium sulfate. After filtration and removal of organic solvent, the residue was chromatographed on a silica gel column (100-200 mesh) with a mixture of petroleum ether and acetone $(4: 1, \mathrm{v} / \mathrm{v})$ as an eluent to give pure compound 9 as a white solid (2.74 g, 74\%). 9: m.p. 75-76 ${ }^{\circ} \mathrm{C} ;{ }^{1} \mathrm{H}$ NMR $\left(\mathrm{CDCl}_{3}, 400 \mathrm{MHz}\right) \delta 7.90$ (d, $J$ $=8.0 \mathrm{~Hz}, 1 \mathrm{H}), 7.86-7.80(\mathrm{~m}, 2 \mathrm{H}), 7.77(\mathrm{~s}, 1 \mathrm{H}), 7.70(\mathrm{t}, J=8.5 \mathrm{~Hz}, 2 \mathrm{H}), 7.37-7.28(\mathrm{~m}$, 5H), 7.24-7.11 (m, 5H), 5.27-5.20 (m, 3H), $4.62(\mathrm{t}, J=4.5 \mathrm{~Hz}, 2 \mathrm{H}), 3.91(\mathrm{t}, J=5.4$ $\mathrm{Hz}, 2 \mathrm{H}), 3.88-3.81(\mathrm{~m}, 2 \mathrm{H}), 3.78(\mathrm{t}, J=5.4 \mathrm{~Hz}, 2 \mathrm{H}), 3.66-3.53(\mathrm{~m} 2 \mathrm{H}) ;{ }^{13} \mathrm{C}\left\{{ }^{1} \mathrm{H}\right\}$ NMR $\left(\mathrm{CDCl}_{3}, 125 \mathrm{MHz}\right) \delta 172.6,171.2,168.6,167.1,167.0,166.5,166.3,139.0$, $138.8,136.5,136.0,135.8,135.2$, 133.0, 132.7, 132.6, 132.2, 128.9, 128.8, 128.7, 128.6, 128.4, 127.2, 125.1, 124.9, 123.9, 123.8, 123.5 (q, $J=286.2 \mathrm{~Hz}), 69.1,68.1$, 68.01, 67.98, 65.2 (quint, $J=26.2 \mathrm{~Hz}$ ), 54.1, 37.7, 34.7; IR (KBr) v 3070, 3028, 2919, 1779, 1720, 1626, 1544, 1511, 1439, 1386, $1255 \mathrm{~cm}^{-1}$; HRMS $\left(\mathrm{APCI}^{+}\right): \mathrm{m} / z$ calc. for $[\mathrm{M}+\mathrm{H}]^{+}\left(\mathrm{C}_{42} \mathrm{H}_{30} \mathrm{O}_{8} \mathrm{~N}_{5} \mathrm{Cl}_{2} \mathrm{~F}_{6}{ }^{+}\right)$916.1370, found 916.1313. 


\section{Synthesis of 10}
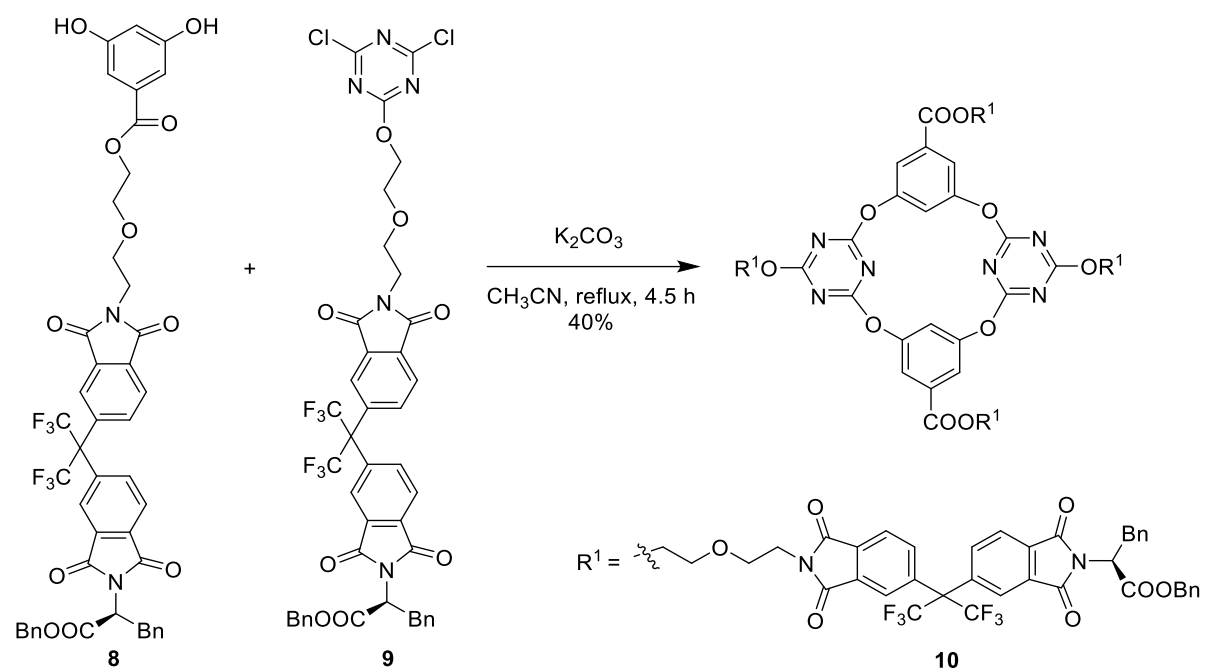

Potassium carbonate (332 mg, $2.4 \mathrm{mmol})$ and acetonitrile (34 mL) were mixed in a two-neck flask and heated to reflux. The solution of $\mathbf{8}(905 \mathrm{mg}, 1 \mathrm{mmol})$ and 9 (917 $\mathrm{mg}, 1 \mathrm{mmol})$ in acetonitrile $(34 \mathrm{~mL})$ was then added dropwise within $0.5 \mathrm{~h}$. The resulting mixture was refluxed for another $4 \mathrm{~h}$ and cooled to room temperature. Acetonitrile was removed by rotary evaporation. The residue dissolved in ethyl acetate $(100 \mathrm{~mL})$ and washed with water and brine two times respectively, and then dried with anhydrous sodium sulfate. After filtration and removal of organic solvent, the residue was chromatographed on a silica gel column (100-200 mesh) with a mixture of dichloromethane and ethyl acetate $(10: 1, \mathrm{v} / \mathrm{v})$ as an eluent to give pure compound 10 as a white solid (716 mg, 40\%). 10: m.p. 130-131 ${ }^{\circ} \mathrm{C} ;{ }^{1} \mathrm{H}$ NMR $\left(\mathrm{CDCl}_{3}\right.$, $500 \mathrm{MHz}) \delta 7.89(\mathrm{~d}, J=8.0 \mathrm{~Hz}, 2 \mathrm{H}), 7.85-7.75(\mathrm{~m}, 14 \mathrm{H}), 7.73-7.62(\mathrm{~m}, 8 \mathrm{H}), 7.51(\mathrm{~d}$, $J=2.2 \mathrm{~Hz}, 4 \mathrm{H}), 7.36-7.28(\mathrm{~m}, 20 \mathrm{H}), 7.23-7.10(\mathrm{~m}, 20 \mathrm{H}), 6.94(\mathrm{t}, J=2.3 \mathrm{~Hz}, 2 \mathrm{H})$, 5.27-5.20 (m, 12H), $4.61(\mathrm{t}, J=5.0 \mathrm{~Hz}, 4 \mathrm{H}), 4.33(\mathrm{t}, J=4.7 \mathrm{~Hz}, 4 \mathrm{H}), 3.96-3.83(\mathrm{~m}$, $12 \mathrm{H}), 3.83-3.71(\mathrm{~m}, 12 \mathrm{H}), 3.67-3.50(\mathrm{~m}, 8 \mathrm{H}) ;{ }^{13} \mathrm{C}\left\{{ }^{1} \mathrm{H}\right\} \mathrm{NMR}\left(\mathrm{CDCl}_{3}, 125 \mathrm{MHz}\right)$ $\delta 174.4,173.1,168.5,167.2,167.1,167.0,166.9,166.50,166.48,166.3,164.3,151.9$, 139.0, 138.9, 138.74, 138.69, 136.5, 136.0, 135.8, 135.2, 133.1, 133.0, 132.9, 132.8, 132.7, 132.6, 132.5, 132.2, 128.9, 128.8, 128.7, 128.6, 128.3, 127.1, 125.02, 124.99, 124.89, 124.87, 124.0, 123.9, 123.80, 123.78, 123.4 (q, $J=286.2 \mathrm{~Hz}), 121.2,120.8$, 68.4, 68.3, 68.2, 68.1, 67.98, 67.96, 65.2 (quint, $J=26.2 \mathrm{~Hz}$ ), 64.7, 54.05, 54.03, 37.7, 
37.6, 34.7; IR (KBr) v 3066, 2921, 1779, 1722, 1717, 1627, 1578, 1558, 1497, 1443, 1386, $1255 \mathrm{~cm}^{-1}$; HRMS (ESI $\left.{ }^{+}\right): m / z$ calc. for $[\mathrm{M}+\mathrm{Na}]^{+}\left(\mathrm{C}_{176} \mathrm{H}_{122} \mathrm{O}_{38} \mathrm{~N}_{14} \mathrm{~F}_{24} \mathrm{Na}^{+}\right)$ 3517.7553, found 3517.7583. Anal. Calcd. for $\mathrm{C}_{176} \mathrm{H}_{122} \mathrm{O}_{38} \mathrm{~N}_{14} \mathrm{~F}_{24}+\mathrm{CHCl}_{3}: \mathrm{C}, 58.79$; H, 3.43; N, 5.42. Found: C, 58.65; H, 3.15; N, 5.24.

\section{Synthesis of 1}

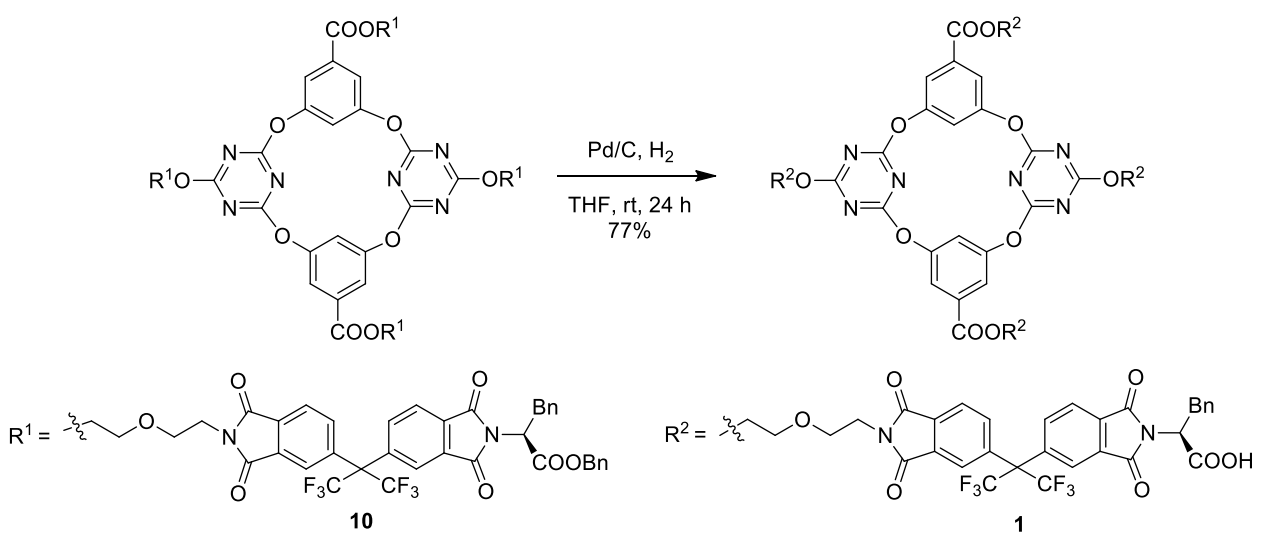

At room temperature, 10 (699 g, $0.2 \mathrm{mmol}), 10 \% \mathrm{Pd} / \mathrm{C}(80 \mathrm{mg})$ and THF (100 $\mathrm{mL}$ ) were mixed in a two-neck flask. The mixture was stirred for $24 \mathrm{~h}$ under $\mathrm{H}_{2}$ balloon. After filtration with siliceousearth, the filtrate was concentrated. The residue was recrystallized with dichloromethane and methanol to give pure compound $\mathbf{1}$ as a white solid (488 mg, 77\%). 1: m.p. 180-181 ${ }^{\circ} \mathrm{C} ;{ }^{1} \mathrm{H} \mathrm{NMR}\left(\mathrm{CDCl}_{3}, 500 \mathrm{MHz}\right) \delta 7.90$ (d, $J=8.0 \mathrm{~Hz}, 2 \mathrm{H}), 7.84-7.64(\mathrm{~m}, 22 \mathrm{H}), 7.45$ (d, $J=1.8 \mathrm{~Hz}, 4 \mathrm{H}), 7.24-7.08$ (m, 20H), $6.90(\mathrm{~s}, 2 \mathrm{H}), 5.28-5.15(\mathrm{~m}, 4 \mathrm{H}), 4.58(\mathrm{~s}, 4 \mathrm{H}), 4.36-4.23(\mathrm{~m}, 4 \mathrm{H}), 3.98-3.44(\mathrm{~m}, 32 \mathrm{H})$; ${ }^{13} \mathrm{C}\left\{{ }^{1} \mathrm{H}\right\} \mathrm{NMR}\left(\mathrm{CDCl}_{3}, 125 \mathrm{MHz}\right) \delta 174.2,173.5,173.4,173.21,173.19,173.0,167.3$, 167.2, 167.1, 166.40, 166.39, 166.37, 166.3, 166.2, 164.3, 151.8, 139.1, 139.0, 138.8, $138.7,136.4,136.0,135.7,135.6,133.0,132.9,132.8,132.7,132.6,132.5,132.4$, $132.1,128.8,127.2,125.2,125.1,125.0,124.02,123.97,123.8,123.4$ (q, $J=286.2$ $\mathrm{Hz}$ ), 121.2, 120.8, 68.4, 68.3, 68.0, 65.2 (quint, $J=26.2 \mathrm{~Hz}$ ), 64.7, 53.52, 53.50, 37.8, 37.6, 34.4; IR (KBr) v 3479, 3065, 2946, 1779, 1738, 1733, 1717, 1699, 1625, 1575, 1568, 1497, 1335, 1255, $1211 \mathrm{~cm}^{-1}$; HRMS $\left(\mathrm{ESI}^{-}\right): \mathrm{m} / z$ calc. for $[\mathrm{M}-3 \mathrm{H}]^{3-}$ $\left(\mathrm{C}_{148} \mathrm{H}_{95} \mathrm{O}_{38} \mathrm{~N}_{14} \mathrm{~F}_{24}{ }^{3-}\right)$ 1043.8522, found 1043.8562. Anal. Calcd. for $\mathrm{C}_{148} \mathrm{H}_{98} \mathrm{O}_{38} \mathrm{~N}_{14} \mathrm{~F}_{24}$ : C, 56.68; H, 3.15; N, 6.25. Found: C, 56.39; H, 3.22; N, 6.17. 


\section{NMR titrations ${ }^{[\mathrm{S} 3]}$}

${ }^{1} \mathrm{H}$ NMR titrations were performed in $\mathrm{CDCl}_{3}$ or $\mathrm{CD}_{3} \mathrm{CN}$ at room temperature. The solutions of 1 in $\mathrm{CDCl}_{3}$ or $\mathrm{CD}_{3} \mathrm{CN}$, and stock solutions of each guest in $\mathrm{CDCl}_{3}$ or $\mathrm{CD}_{3} \mathrm{CN}$ were prepared respectively. Aliquots of guest solution were added directly to an NMR tube containing the host solution. All proton signals were referenced to the TMS or solvent residual peak. The association constants $K$ were calculated by Bindfit $v 0.5$ (for this program, please see: http://app.supramolecular.org/bindfit/). The 1:2 stoichiometry was verified by a Job's plot experiment for binding of 1 with $\mathrm{Cl}^{-}$ (Figure S3c).

Table S1. Association constants $K$ of 1 with $\mathrm{Bu}_{4} \mathrm{~N}^{+} \mathrm{Cl}^{-}$and $\mathrm{Bu}_{4} \mathrm{~N}^{+} \mathrm{Br}^{-}$calculated by Bindfit v0.5 with a host-guest stoichiometry of 1:2.

\begin{tabular}{lll}
\hline & $\mathrm{Bu}_{4} \mathrm{~N}^{+} \mathrm{Cl}^{-}$ & $\mathrm{Bu}_{4} \mathrm{~N}^{+} \mathrm{Br}^{-}$ \\
\hline$K_{1}\left(\mathrm{M}^{-1}\right)$ & $136.3 \pm 3.7$ & $21.3 \pm 1.9$ \\
$K_{2}\left(\mathrm{M}^{-1}\right)$ & $147.5 \pm 4.2$ & $23.9 \pm 1.7$ \\
\hline
\end{tabular}



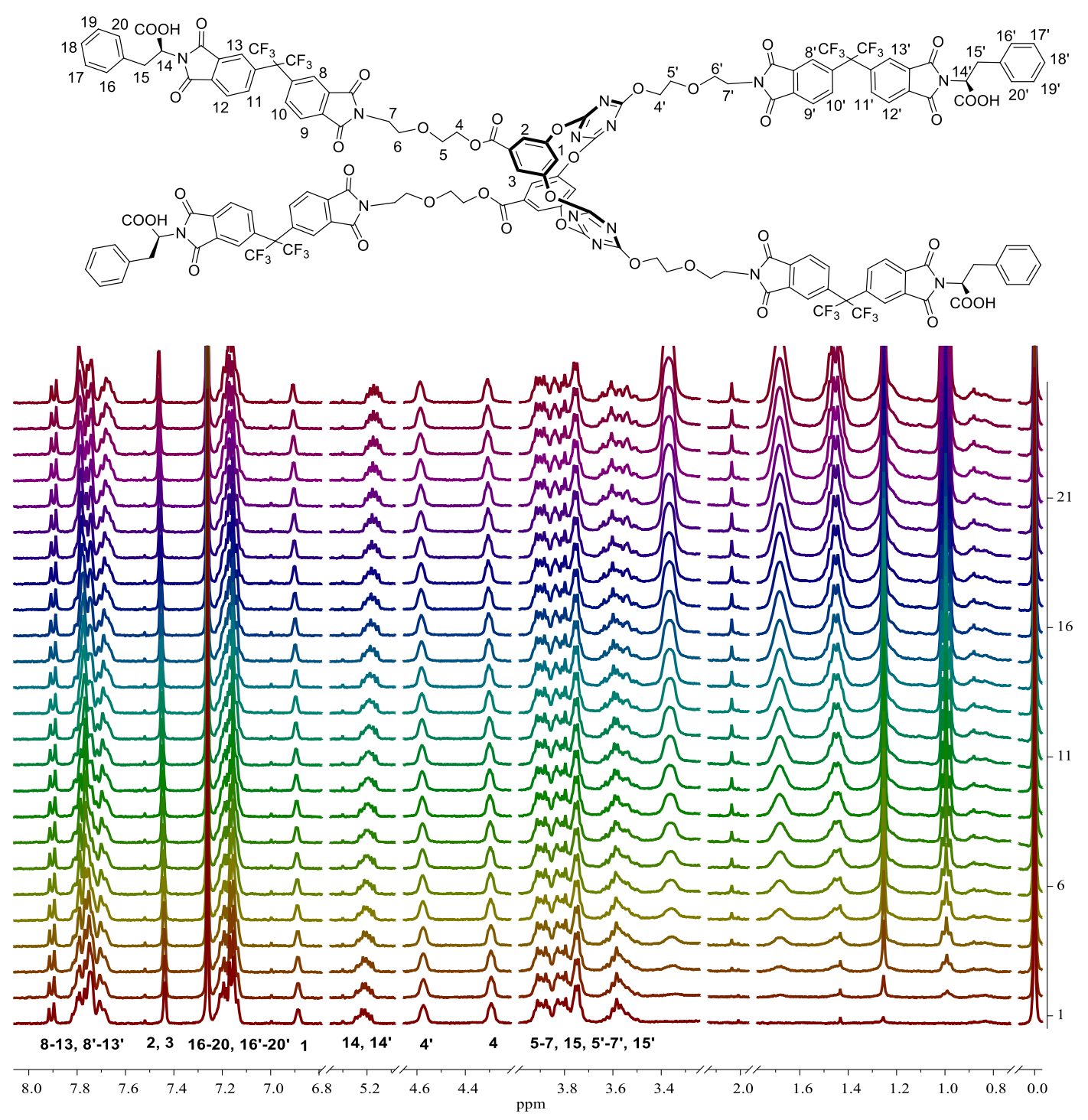

Figure S1. ${ }^{1} \mathrm{H}$ NMR titration of $1\left(1 \times 10^{-3} \mathrm{~mol} / \mathrm{L}\right.$ in $\left.\mathrm{CDCl}_{3}\right)$ upon addition of different amounts of tetrabutylammonium chloride (from bottom to top: $0,0.2,0.4$, $0.6,0.8,1.0,1.2,1.4,1.6,1.8,2.0,2.2,2.3,2.5,2.7,2.9,3.1,3.3,3.5,3.7,3.8,4.0,4.2$, $\left.4.4,4.6 \times 10^{-3} \mathrm{~mol} / \mathrm{L}\right)$. Upon addition of chloride, the $\alpha$-proton on phenylalanine moiety (H14, H14') moved upfield, indicating interaction of the carboxylic acid site with chloride. Some benzene imide protons (H8-H13, H8'-H13') also shifted upfield, probably a result of shielding effect of the approaching chloride upon anion- $\pi$ contacting with the electron-deficient imide. The continuous downfield movement of the inner proton (H1) within the macrocyclic V-shaped cavity suggested anion- $\pi$ interaction between the triazine and chloride, in line with our previous observations. For clarity, partial spectra are shown. 


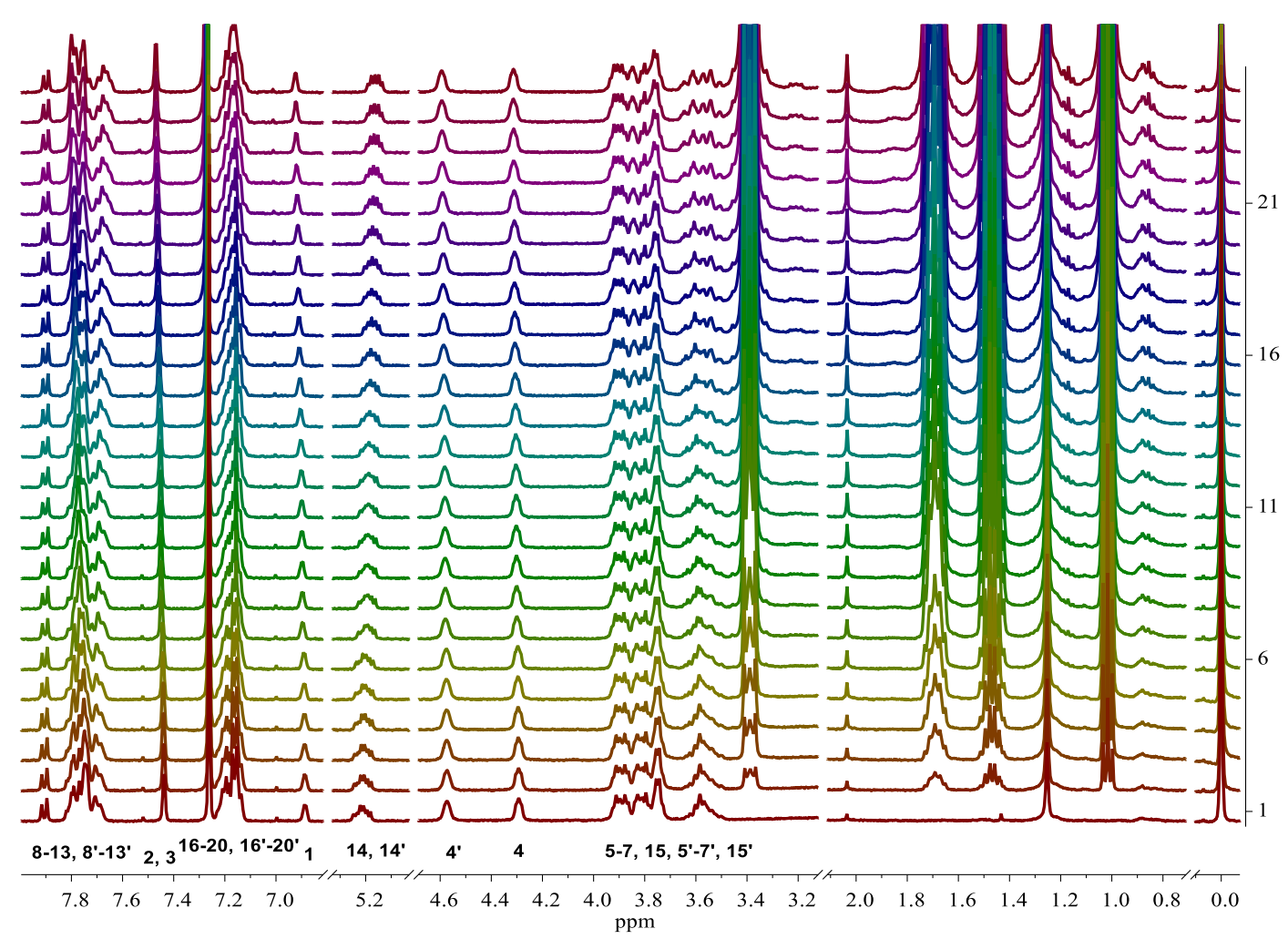

Figure S2. ${ }^{1} \mathrm{H}$ NMR titration of $1\left(1 \times 10^{-3} \mathrm{~mol} / \mathrm{L}\right.$ in $\left.\mathrm{CDCl}_{3}\right)$ upon addition of different amounts of tetrabutylammonium bromide (from bottom to top: 0, 1.0, 2.0, 3.0, 4.0, 5.0, 10.0, 11.0, 11.5, 12.5, 13.5, 14.5, 15.5, 17.0, 19.0, 21.0, 23.0, 24.0, 25.0, $\left.26.5,28.0,30.0,32.0,33.5,35.0 \times 10^{-3} \mathrm{~mol} / \mathrm{L}\right)$. For clarity, partial spectra are shown.

a

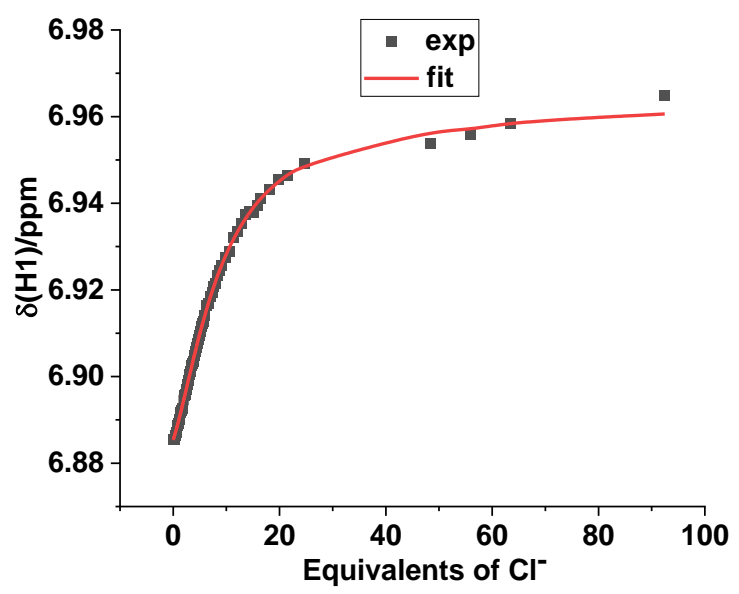

b

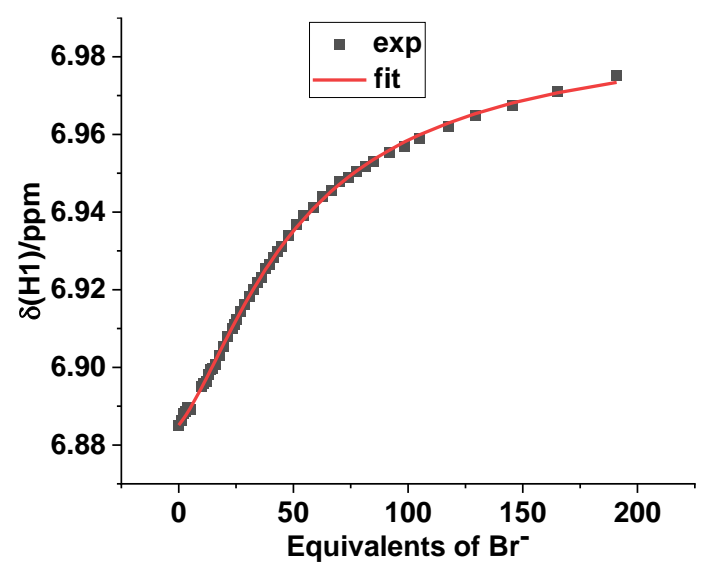




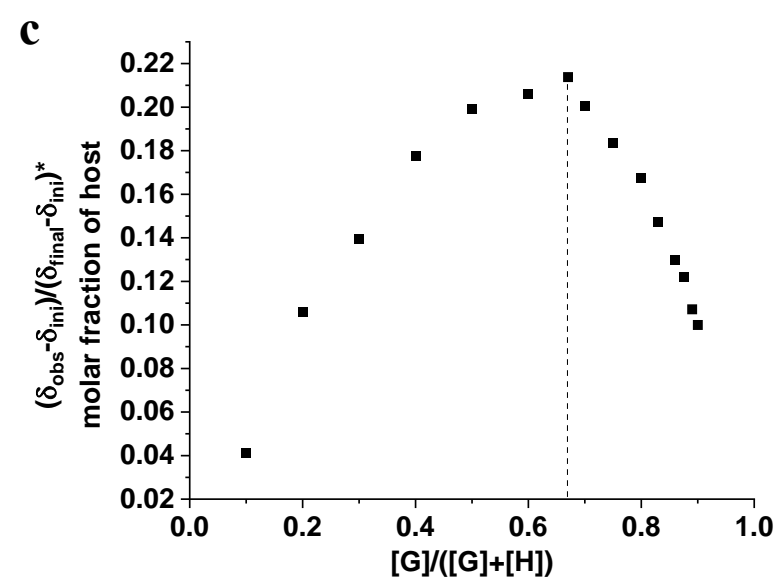

Figure S3. Fitting plots of the chemical shifts of proton H1 of 1 with increasing concentration of (a) $\mathrm{Bu}_{4} \mathrm{NCl}$ and (b) $\mathrm{Bu}_{4} \mathrm{NBr}$ using Bindfit v0.5 program. (c) Job-plot for complex between $\mathbf{1}$ and $\mathrm{Cl}^{-}$.

(a)

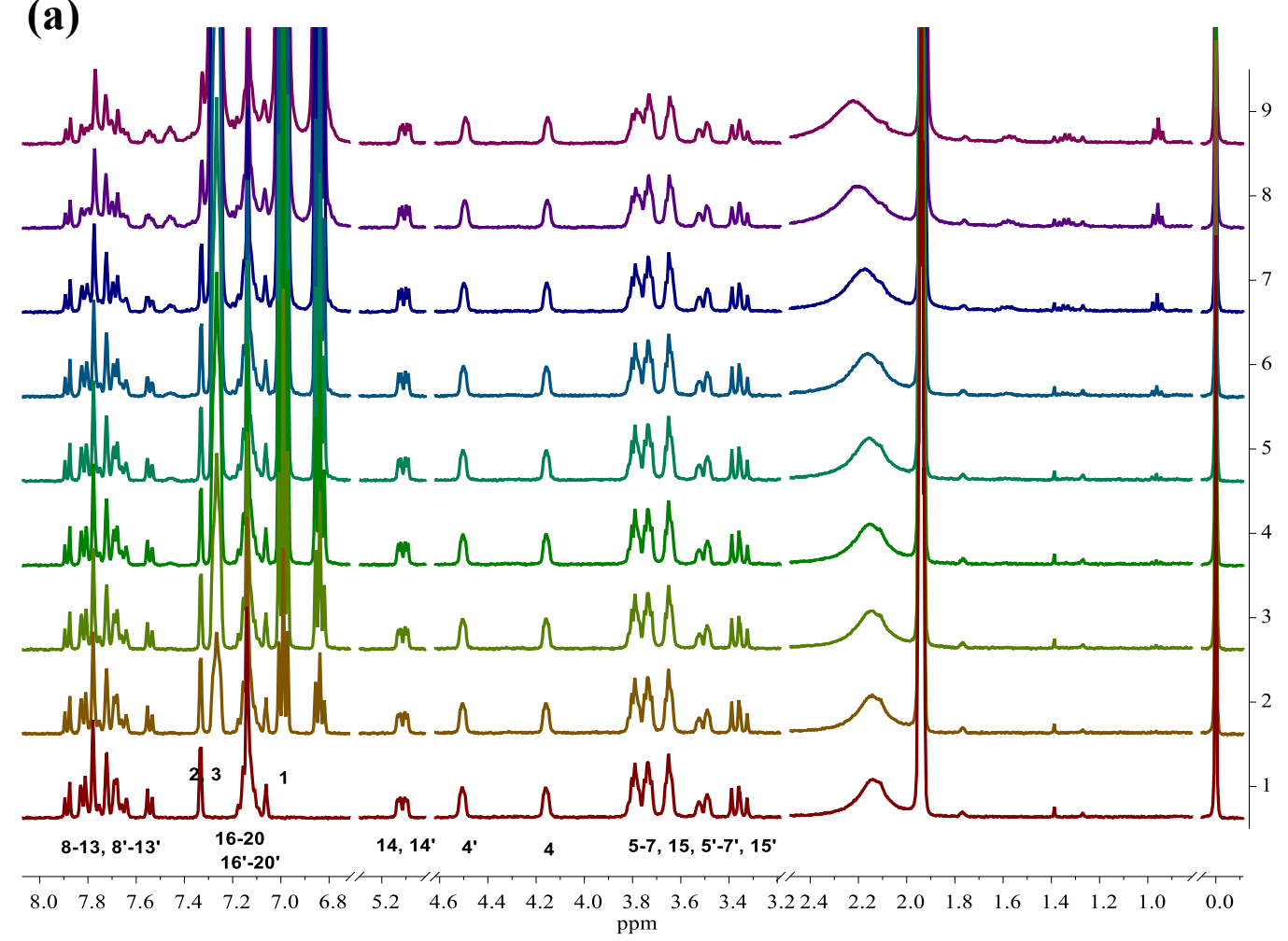



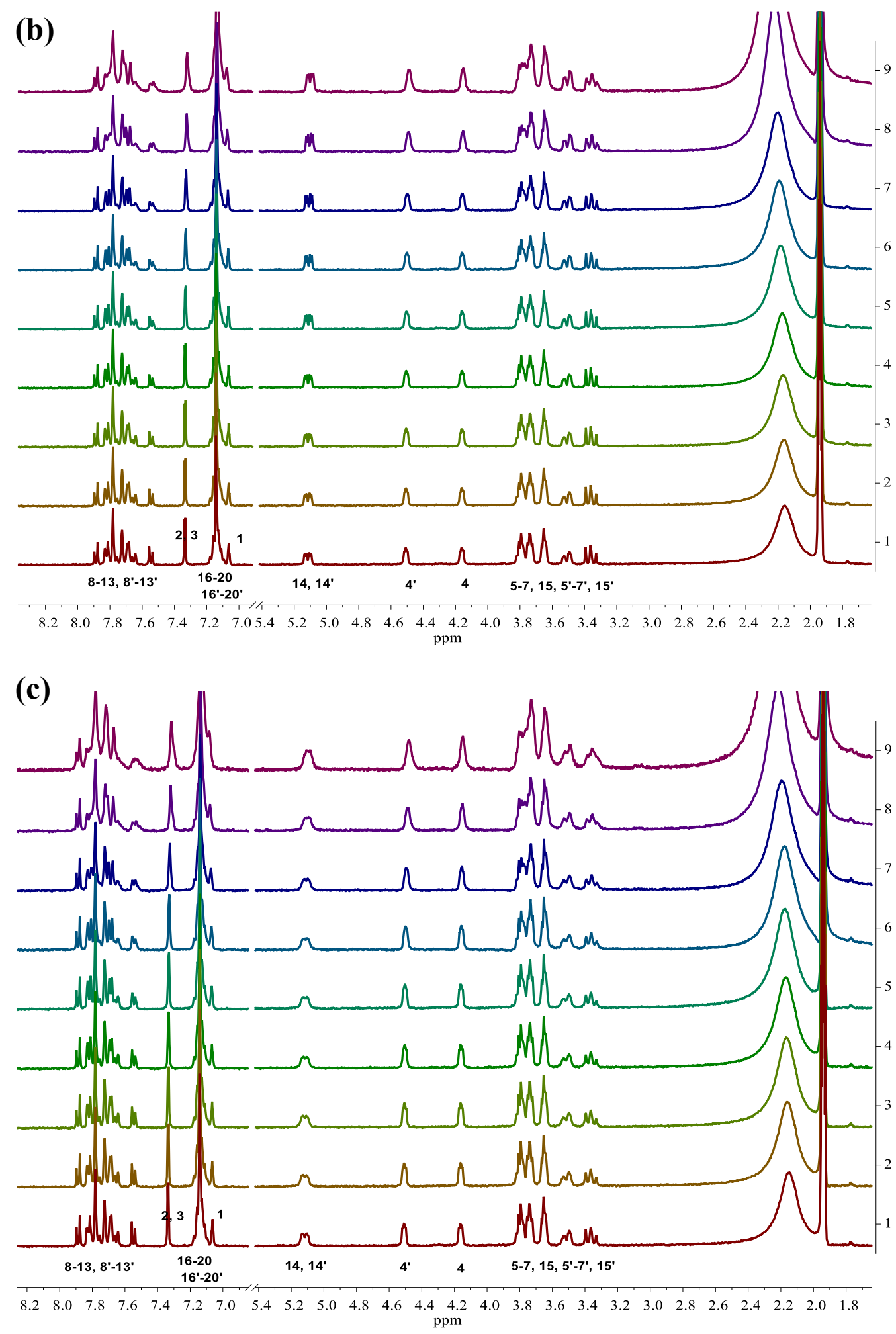

Figure S4. ${ }^{1} \mathrm{H}$ NMR titration of $1\left(1 \times 10^{-3} \mathrm{~mol} / \mathrm{L}\right.$ in $\left.\mathrm{CD}_{3} \mathrm{CN}\right)$ upon addition of different amounts of various cationic salts. (a) $\mathrm{NaBPh}_{4}$, from bottom to top: $0,2.0,4.0$, 6.0, 8.0, 12.0, 19.0, 36.0, $52.0 \times 10^{-3} \mathrm{~mol} / \mathrm{L}$. (b) $\mathrm{NaPF}_{6}$, from bottom to top: $0,2.0,4.0$, 6.0, 8.5, 13.0, 20.0, 37.0, $53.0 \times 10^{-3} \mathrm{~mol} / \mathrm{L}$. (c) $\mathrm{KPF}_{6}$, from bottom to top: $0,2.0,4.0$, $6.0,7.5,13.0,21.0,37.0,51.0 \times 10^{-3} \mathrm{~mol} / \mathrm{L}$. In all spectra, the chemical shift changes of the essential protons are very small $(\Delta \delta<0.01 \mathrm{ppm})$, showing weak binding ability towards the cations. $\mathrm{KBPh}_{4}$ was not used due to its poor solubility. 


\section{Ion transport activity and DPPC assays ${ }^{[\mathrm{S} 3, \mathrm{~S} 4]}$}

General preparation of Lucigenin or HPTS containing EYPC-LUVs. Egg yolk phosphatidylcholine (EYPC, $25 \mathrm{mg}$ ) was dissolved in $\mathrm{EtOH} / \mathrm{CHCl}_{3}(2 \mathrm{~mL}$, v/v 1:1). The solution was evaporated under reduced pressure on a rotary evaporator (40 $\left.{ }^{\circ} \mathrm{C}\right)$ to give a thin film, and the resulting thin film was dried under high vacuum for overnight to remove the residual solvent. The lipid film was hydrated in $1.0 \mathrm{~mL}$ buffer solution $\left(10 \mathrm{mM}\right.$ HEPES $+100 \mathrm{mM} \mathrm{NaNO}_{3}+1 \mathrm{mM}$ Lucigenin, $\mathrm{pH}=7.0 ; 10 \mathrm{mM}$ HEPES $+100 \mathrm{mM} \mathrm{NaCl}+1 \mathrm{mM}$ HPTS, $\mathrm{pH}=7.0$ ) for $20 \mathrm{mins}$ at room temperature. The suspension was submitted to freeze-thaw for 5 cycles (with liquid nitrogen and 50 ${ }^{\circ} \mathrm{C}$ water bath, respectively), and high-pressure extrusion at room temperature (21 times extrusions through polycarbonate membrane with pore diameter of $100 \mathrm{~nm}$ ). The LUV suspension was separated from extravesicular Lucigenin or HPTS dye by size exclusion chromatography (Sephadex G-50, mobile phase: $10 \mathrm{mM}$ HEPES +100 $\mathrm{mM} \mathrm{NaNO}, \mathrm{pH}=7.0 ; 10 \mathrm{mM}$ HEPES $+100 \mathrm{mM} \mathrm{NaCl}, \mathrm{pH}=7.0$ ).

General preparation of Lucigenin containing DPPC-LUVs. DPPC (25 mg) was dissolved in $\mathrm{MeOH} / \mathrm{CHCl}_{3}(2 \mathrm{~mL}$, v/v 1:1). The solution was evaporated under reduced pressure on a rotary evaporator $\left(50^{\circ} \mathrm{C}\right)$ to give a thin film, and the resulting thin film was dried under high vacuum for overnight to remove the residual solvent. The lipid film was hydrated in $1.0 \mathrm{~mL}$ buffer solution $(10 \mathrm{mM}$ HEPES $+100 \mathrm{mM}$ $\mathrm{NaNO}_{3}+1 \mathrm{mM}$ Lucigenin, $\mathrm{pH}=7.0$ ) for $20 \mathrm{mins}$ at $50{ }^{\circ} \mathrm{C}$. The suspension was submitted to freeze-thaw for 5 cycles (with liquid nitrogen and $50{ }^{\circ} \mathrm{C}$ water bath, respectively), and high-pressure extrusion at $65{ }^{\circ} \mathrm{C}$ (21 times extrusions through polycarbonate membrane with pore diameter of $100 \mathrm{~nm}$ ). The LUV suspension was separated from extravesicular Lucigenin dye by size exclusion chromatography (Sephadex G-50, mobile phase: $10 \mathrm{mM}$ HEPES + $100 \mathrm{mM} \mathrm{NaNO}_{3}, \mathrm{pH}=7.0$ ).

Lucigenin fluorescence assay. $50 \mu \mathrm{L}$ Lucigenin-loaded EYPC-LUV solution was suspended in $1950 \mu \mathrm{L}$ of the buffer solution $(10 \mathrm{mM}$ HEPES $+100 \mathrm{mM} \mathrm{NaCl}$, 
$\mathrm{KCl}$ or $\mathrm{NaBr}, \mathrm{pH}=7.0$ ) and placed into a quartz cuvette at $25^{\circ} \mathrm{C}$. The intravesicular Lucigenin fluorescence intensity $\left(I_{t}, \lambda_{\mathrm{ex}}=369 \mathrm{~nm}, \lambda_{\mathrm{em}}=505 \mathrm{~nm}\right)$ was measured over time. THF or the solution of compound $\mathbf{1}$ or $\mathbf{1 0}$ in THF $(25 \mu \mathrm{L})$ was added at $\mathrm{t}=50 \mathrm{~s}$ $\left(I_{0}\right)$, and then triton $\mathrm{X}-100(25 \mu \mathrm{L}, 10 \%$ in water $)$ was added at $500 \mathrm{~s}\left(I_{\infty}\right)$. The fluorescence intensity $I_{t}$ was normalized to fractional intensity $I_{f}$ using equation (S1):

$$
I_{f}=\left(I_{t}-I_{\infty}\right) /\left(I_{0}-I_{\infty}\right)
$$

Where $I_{0}$ is the fluorescence intensity after addition of THF or compounds, and $I_{\infty}$ is the fluorescence intensity after addition of triton X-100.

The effective concentration $E C_{50}$ and the Hill coefficient $n$ were obtained by Hill equation (S2):

$$
Y=Y_{\infty}+\left(Y_{0}-Y_{\infty}\right) /\left[1+\left(c / E C_{50}\right)^{\mathrm{n}}\right]
$$

Where $Y$ is the $I_{f}$ value at $300 \mathrm{~s}, Y_{0}$ is $Y$ in the absence of compound, $Y_{\infty}$ is $Y$ with excess compound, and $c$ is the compound concentration in the cuvette.

The molar ratio of 1 to lipid was obtained through dividing $\mathrm{EC}_{50}(\mu \mathrm{M})$ by the concentration $(\mu \mathrm{M})$ of lipid in the quartz cuvette.
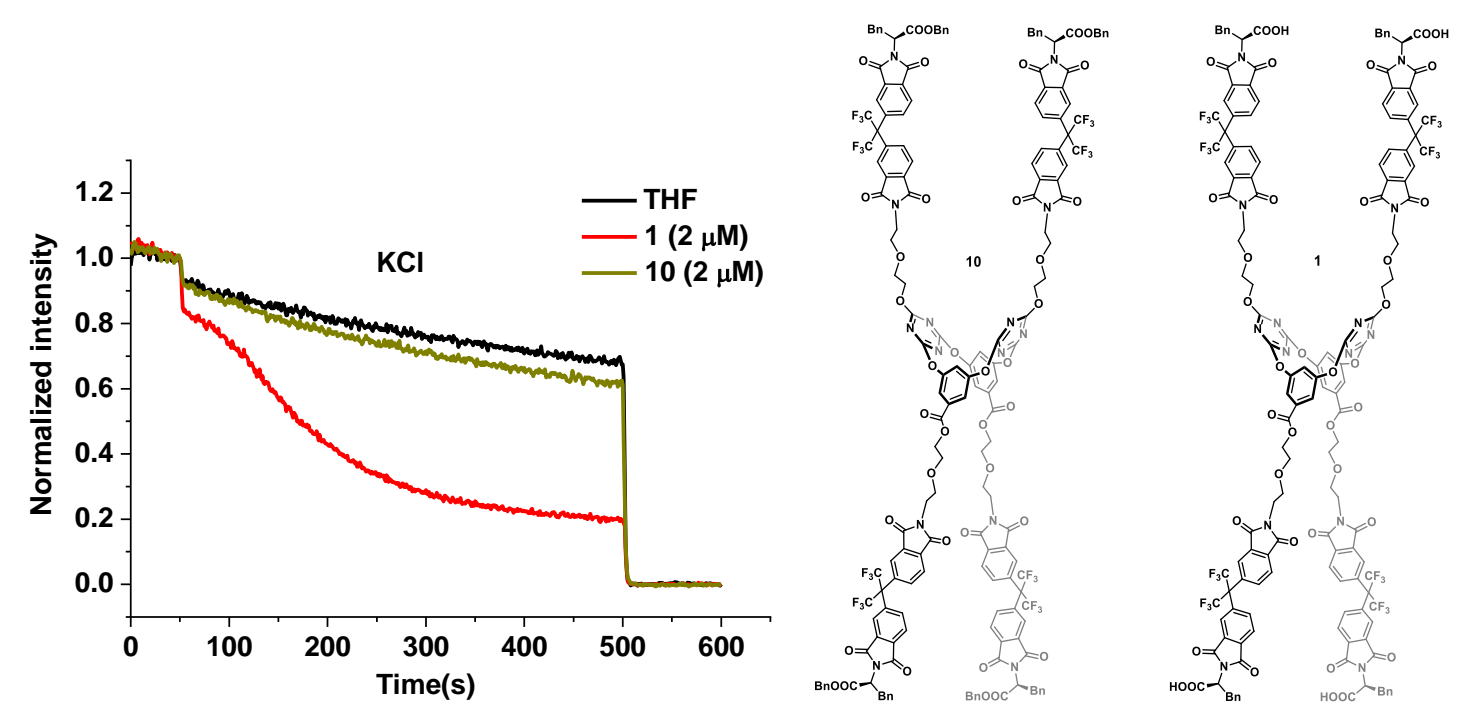

Figure S5. Evaluation of the ion transport activity of compound $\mathbf{1}$ and $\mathbf{1 0}$ by Lucigenin $\subset E Y P C-L U V$ fluorescence assay in $\mathrm{KCl}$ buffer solution (the final concentration for $\mathbf{1}$ and $\mathbf{1 0}$ is $2 \mu \mathrm{M}$.). 
Evaluation of $E C_{50}$ of 1 in different buffer solutions
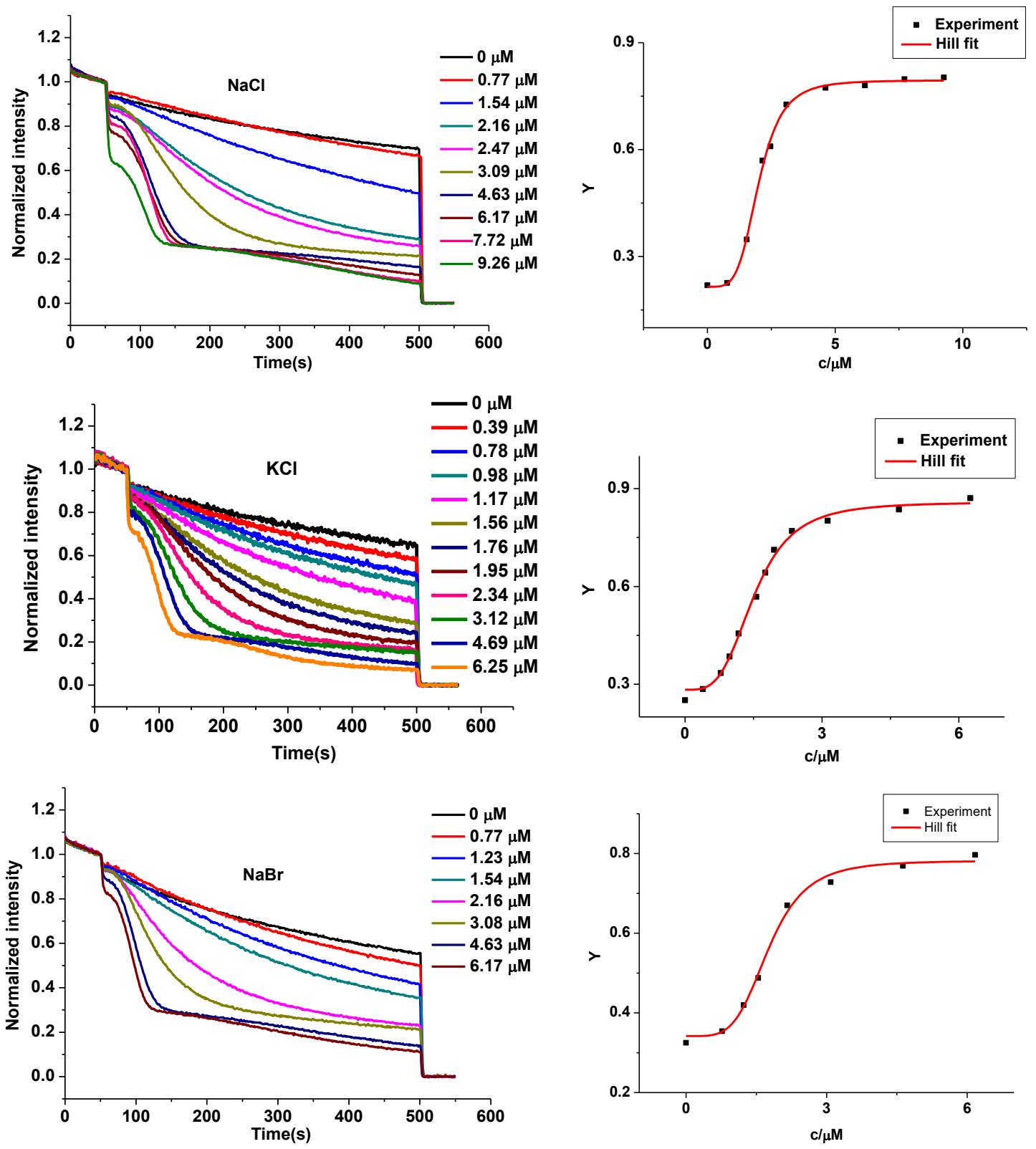

Figure S6. Evaluation of the ion transport activity of $\mathbf{1}$ in varied concentrations by Lucigenin $\subset$ EYPC-LUV fluorescence assay, and Hill fit of the normalized intensities at $300 \mathrm{~s}$.

Table S2. $\mathrm{EC}_{50}(\mu \mathrm{M})$, mol\% of transporter to lipid and Hill coefficient $n$ of $\mathbf{1}$ in $\mathrm{NaCl}$, $\mathrm{KCl}, \mathrm{NaBr}$ buffer solution.

\begin{tabular}{ccccc}
\hline & & $\mathrm{NaCl}$ & $\mathrm{KCl}$ & $\mathrm{NaBr}$ \\
\hline & $\mathrm{EC}_{50}$ & $2.00 \pm 0.04$ & $1.50 \pm 0.05$ & $1.76 \pm 0.07$ \\
$\mathbf{1}$ & $\mathrm{mol} \%$ & 1.49 & 1.12 & 1.31 \\
& $\mathrm{n}$ & $4.3 \pm 0.3$ & $3.5 \pm 0.3$ & $4.3 \pm 0.7$ \\
\hline
\end{tabular}


HPTS assay. ${ }^{[\mathrm{S} 5]} 50 \mu \mathrm{L}$ HPTS-loaded vesicle solution was suspended in $1950 \mu \mathrm{L}$ of the buffer solution (solution 1: $10 \mathrm{mM}$ HEPES + $100 \mathrm{mM} \mathrm{NaX}, \mathrm{X}=\mathrm{Cl}, \mathrm{Br}, \mathrm{I}, \mathrm{NO}_{3}$, $\mathrm{ClO}_{4}, \mathrm{pH}=7.0$; solution 2: $10 \mathrm{mM}$ HEPES + $100 \mathrm{mM} \mathrm{MCl,} \mathrm{M}=\mathrm{Li}, \mathrm{Na}, \mathrm{K}, \mathrm{Rb}, \mathrm{Cs}$, $\mathrm{pH}=7.0$ ) and placed into a quartz cuvette at $25{ }^{\circ} \mathrm{C}$. The intravesicular HPTS

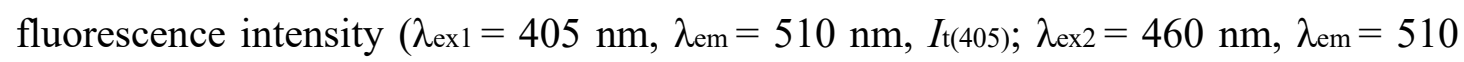

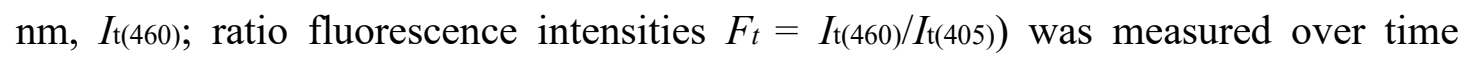
during the addition of base $(20 \mu \mathrm{L} \mathrm{NaOH}(0.5 \mathrm{M})$ for creating $\mathrm{pH}$ gradient $)$ at $\mathrm{t}=50 \mathrm{~s}$, THF or THF solution of $1(25 \mu \mathrm{L})$ at $\mathrm{t}=150 \mathrm{~s}$, and $10 \%$ Trion $\mathrm{X}-100(25 \mu \mathrm{L})$ at $\mathrm{t}=$ $450 \mathrm{~s}$, respectively. Fluorescence time courses were normalized to fractional emission intensity $\mathrm{I}^{\mathrm{n}}$ using equation (S3):

$$
\mathrm{I}^{\mathrm{n}}=\left(F_{t}-F_{0}\right) /\left(F_{\infty}-F_{0}\right)
$$

Where $F_{0}$ is the ratio fluorescence intensity after addition of $\mathbf{1}$, and $F_{\infty}$ is ratio fluorescence intensity after addition of Triton X-100. The baseline (THF only) $\mathrm{I}_{0}{ }_{0}$ was then subtracted from $\mathrm{I}^{\mathrm{n}}$ to give I (S4):

$$
\mathrm{I}=\mathrm{I}^{\mathrm{n}}-\mathrm{I}_{0}^{\mathrm{n}}
$$

The obtained I was further normalized into fractional HPTS emission $\mathrm{I}_{\mathrm{F}}$ using equation (S5)

$$
\mathrm{I}_{\mathrm{F}}=\mathrm{I} / \mathrm{I}_{\mathrm{MAX}}
$$

where $\mathrm{I}_{\mathrm{MAX}}$ is a reference emission for the varied parameter of interest.

The time axis was normalized according to Equation (S6):

$$
\mathrm{t}=\mathrm{t}-150
$$


a

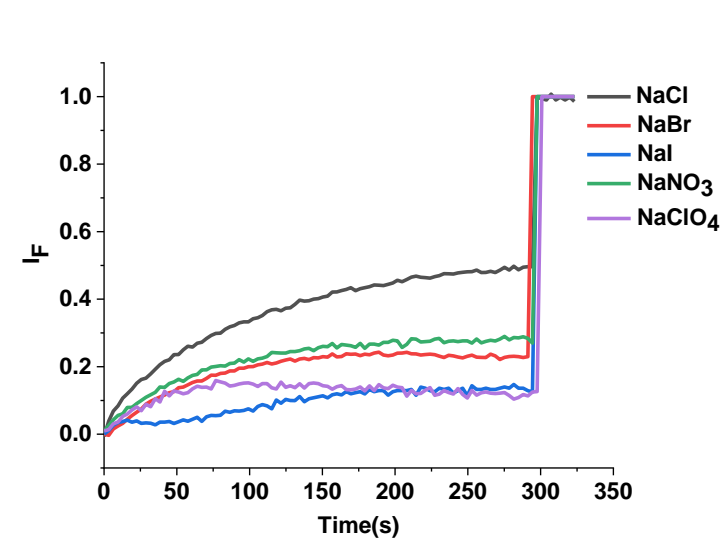

b

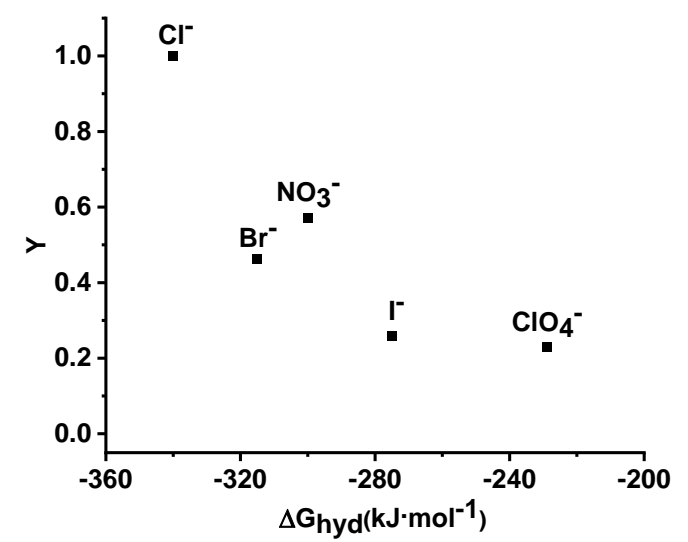

Figure S7. (a) Normalized anion transport activities of $1(2 \mu \mathrm{M})$ with varied extravesicular anions $\mathrm{NaX}\left(10 \mathrm{mM}\right.$ HEPES, $100 \mathrm{mM} \mathrm{NaX}, \mathrm{X}=\mathrm{Cl}, \mathrm{Br}, \mathrm{I}_{2} \mathrm{NO}_{3}, \mathrm{ClO}_{4}$, $\mathrm{pH}=7.0$ ) by HPTS $\subset$ EYPC-LUV fluorescence assay. Background activities without 1 were subtracted after calibration. (b) HPTS assay for anion selectivity. Fractional activity $\mathrm{Y}$ was relative to $\mathrm{NaCl}$.

$\mathbf{a}$

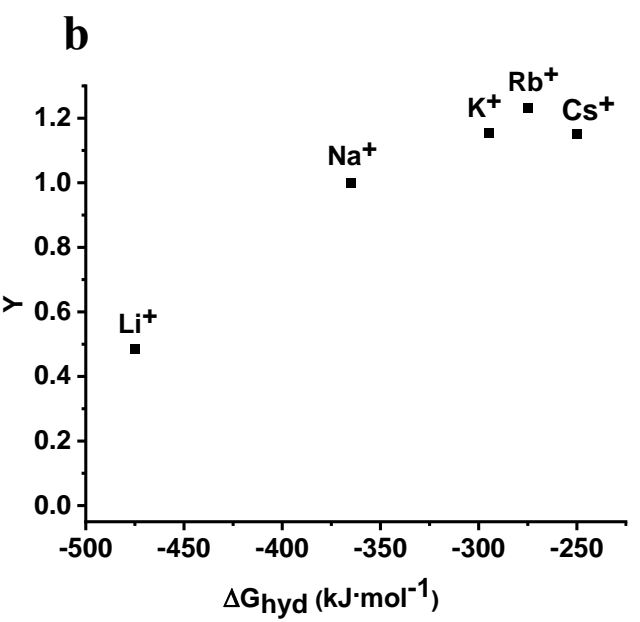

Figure S8. (a) Normalized cation transport activities of $1(2 \mu \mathrm{M})$ with varied extravesicular cations $\mathrm{MCl}(10 \mathrm{mM}$ HEPES, $100 \mathrm{mM} \mathrm{MCl}, \mathrm{M}=\mathrm{Li}, \mathrm{Na}, \mathrm{K}, \mathrm{Rb}, \mathrm{Cs}$, $\mathrm{pH}=7.0$ ) by HPTS $\subset$ EYPC-LUV fluorescence assay. Background activities without $\mathbf{1}$ were subtracted after calibration. (b) HPTS assay for cation selectivity. Fractional activity $\mathrm{Y}$ was relative to $\mathrm{NaCl}$.

DPPC assay. $50 \mu \mathrm{L}$ Lucigenin-loaded DPPC-LUV solution was suspended in $1950 \mu \mathrm{L}$ of $\mathrm{NaCl}$ buffer solution (10 mM HEPES $+100 \mathrm{mM} \mathrm{NaCl}, \mathrm{pH}=7.0)$ and placed into a quartz cuvette at $25{ }^{\circ} \mathrm{C}$. The intravesicular Lucigenin fluorescence intensity $\left(I_{t}, \lambda_{\mathrm{ex}}=369 \mathrm{~nm}, \lambda_{\mathrm{em}}=505 \mathrm{~nm}\right)$ was measured over time at $25^{\circ} \mathrm{C}$. THF or the solution of compound 1 in THF $(25 \mu \mathrm{L})$ was added at $\mathrm{t}=50 \mathrm{~s}\left(I_{0}\right)$, and then triton 
X-100 $(25 \mu \mathrm{L}, 10 \%$ in water $)$ was added at $300 \mathrm{~s}\left(I_{\infty}\right)$. The fluorescence intensity $I_{t}$ was normalized to fractional intensity $I_{f}$ using equation (S7):

$$
I_{f}=\left(I_{t}-I_{\infty}\right) /\left(I_{0}-I_{\infty}\right)
$$

Where $I_{0}$ is the fluorescence intensity after addition of THF or compound, and $I_{\infty}$ is the fluorescence intensity after addition of triton $\mathrm{X}-100$.

For DPPC assay at $45{ }^{\circ} \mathrm{C}$, the intravesicular Lucigenin fluorescence intensity was measured over time at $45^{\circ} \mathrm{C}$. The other processes are the same as that mentioned above.

\section{DPPC test results}

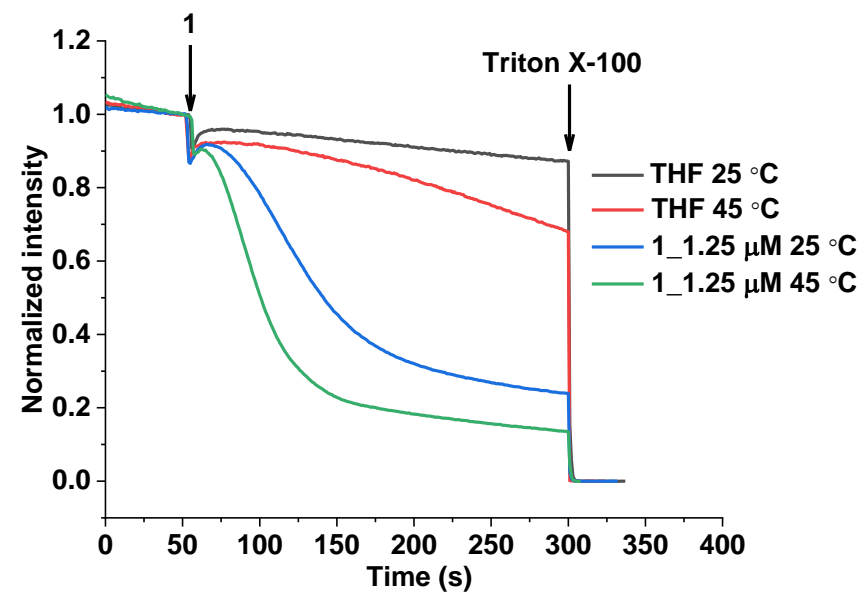

Figure S9. $\mathrm{Cl}^{-}$transport by 1 in Lucigenin-loaded DPPC-LUV at $25{ }^{\circ} \mathrm{C}$ and $45{ }^{\circ} \mathrm{C}$, the molar ratio of 1 to lipid is $1: 112$. 


\section{Planar lipid bilayer experiments ${ }^{[66]}$}

The chloroform solution of 1,2-diphytanoyl-sn-glycero-3-phosphocholine (DPhPC, $25 \mathrm{mg} / \mathrm{mL}, 10 \mu \mathrm{L}$ ) was evaporated using nitrogen gas and dissolved in $n$-decane $(25 \mu \mathrm{L}) .0 .5 \mu \mathrm{L}$ of the $n$-decane solution was painted onto the aperture of the Delrin cup (diameter $=200 \mu \mathrm{m}$, Warner Instruments) and the $n$-decane was removed with nitrogen gas. In a traditional planar lipid bilayer conductance measurement experiment, the chamber (cis side) and the Delrin cup (trans side) were filled with 1.0 $\mathrm{M} \mathrm{KCl}$ aqueous solution $(1.0 \mathrm{~mL}) . \mathrm{Ag}-\mathrm{AgCl}$ electrodes were placed into the two solutions with the trans side grounded. Planar lipid bilayer was formed by painting $0.5 \mu \mathrm{L}$ of the above mentioned $n$-decane solution around the pretreated aperture. The formation of planar lipid bilayer was confirmed by capacitance value ranging from 80 to $120 \mathrm{pF}$. THF or compound 1 in THF $(0.5 \mu \mathrm{L})$ was added to the $c i s$ chamber to reach a final concentration of around $10^{-7} \mathrm{M}$, and the solution was stirred for about five minutes. Then the baseline and current signals were recorded at different holding potentials in a Faraday cage, amplified with BC-535 bilayer clamp amplifier (Warner Instruments), low-pass filtered with an 8-pole Bessel filter at $1 \mathrm{kHz}$ (LPF-8, Warner Instruments), A-D converted (1550B, Axon Instruments), and sampled with a sample interval at $10 \mathrm{kHz}$ by Clampex 10.6, The data were analyzed by Clampfit 10.6 with a digital filter at $100 \mathrm{~Hz}$. All the measurements were performed at room temperature ( $c a$. $\left.25{ }^{\circ} \mathrm{C}\right)$.

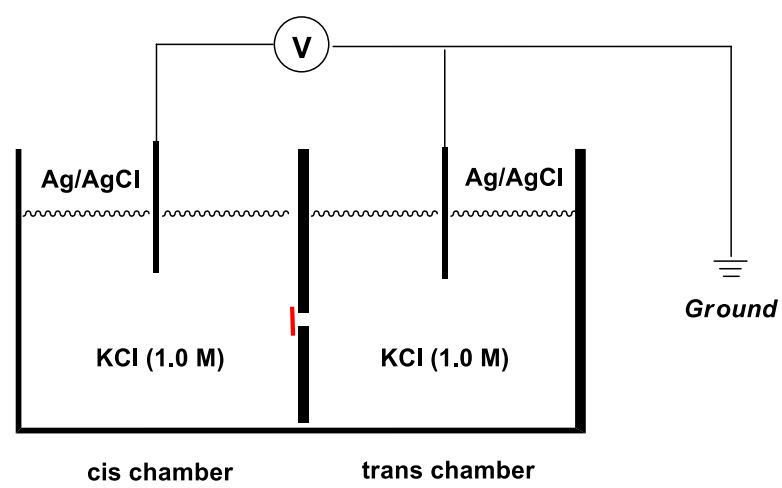

Figure S10. Schematic diagram of the planar lipid bilayer experiments. Experimental conditions: DPhPC in $n$-decane $(10 \mathrm{mg} / \mathrm{mL})$; cis/trans $=1.0 \mathrm{M} / 1.0 \mathrm{M} \mathrm{KCl}$ solution( 1 $\mathrm{mL} / 1 \mathrm{~mL}$ ); applied voltages: $150 \mathrm{mV}, 100 \mathrm{mV}, 60 \mathrm{mV}, 0 \mathrm{mV},-60 \mathrm{mV},-100 \mathrm{mV},-150$ $\mathrm{mV}$; addition: $0.5 \mu \mathrm{L}$ THF solution of channel molecule $1(1 \mathrm{mM})$, final concentration is $0.5 \mu \mathrm{M}$. 

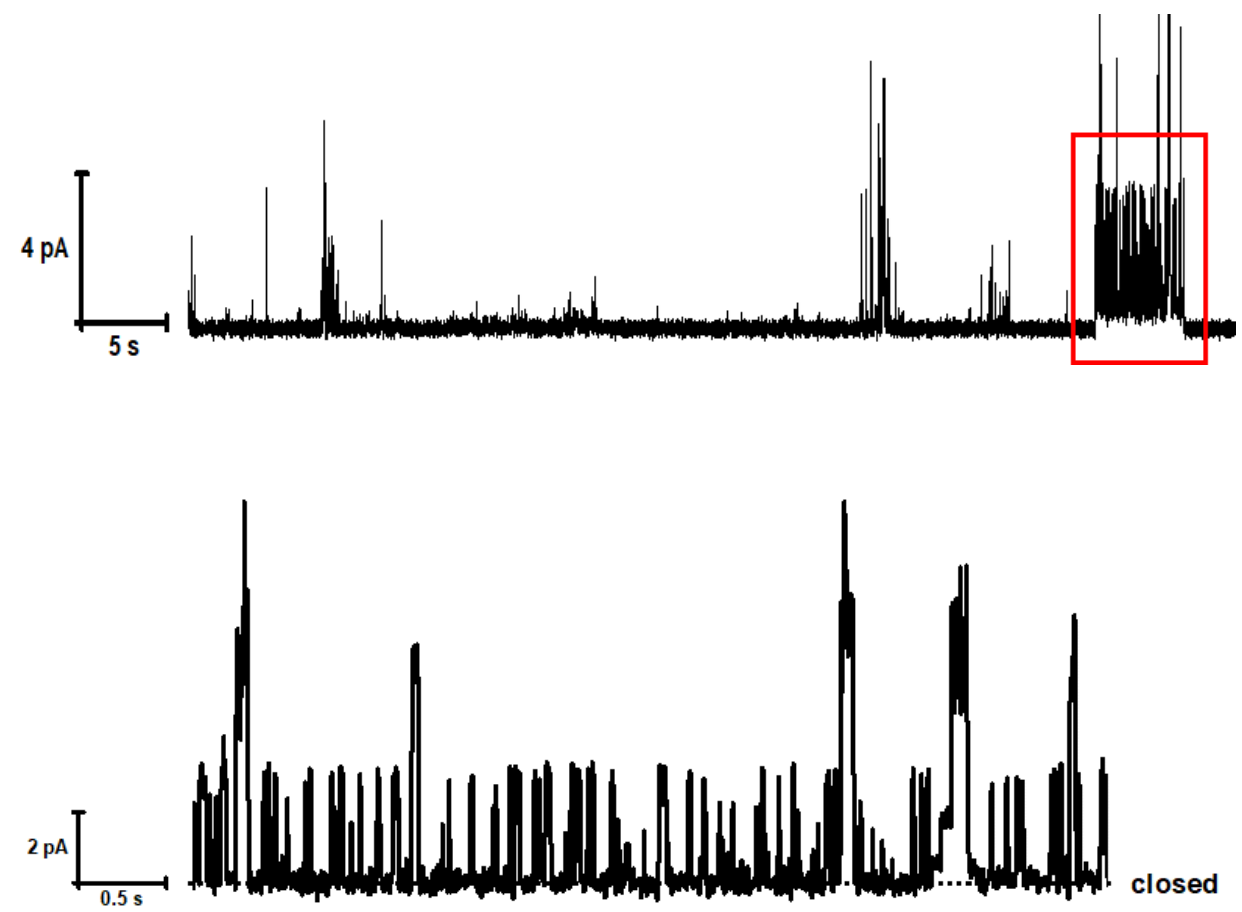

Figure S11. Current traces of channel molecule 1 at $150 \mathrm{mV}$ in symmetrical $\mathrm{KCl}$ solutions $($ cis/trans $=1.0 \mathrm{M} / 1.0 \mathrm{M})$, final concentration is $0.5 \mu \mathrm{M}$. Top, full spectra; bottom, enlarged spectra.
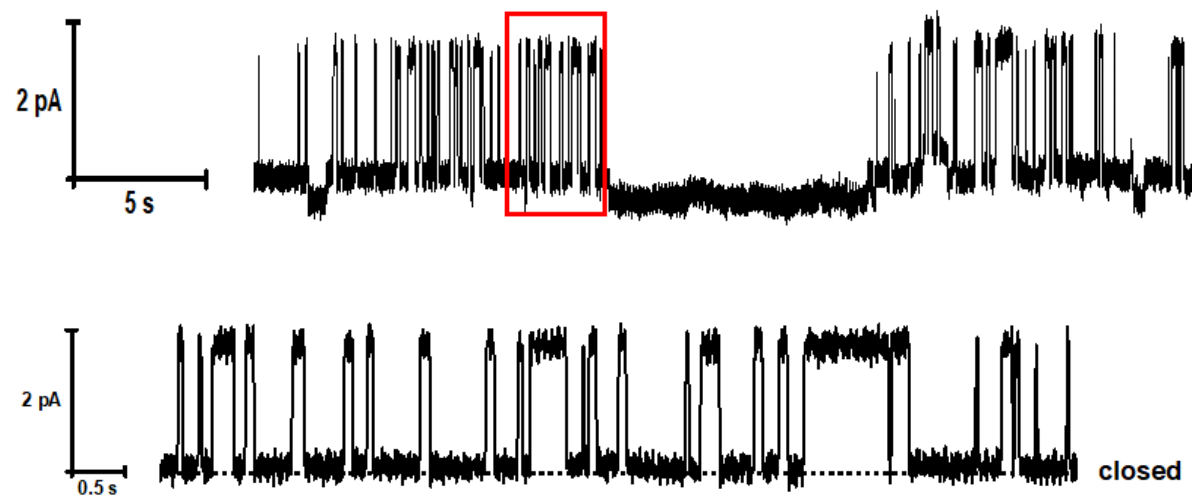

Figure S12. Current traces of channel molecule 1 at $100 \mathrm{mV}$ in symmetrical $\mathrm{KCl}$ solutions (cis/trans $=1.0 \mathrm{M} / 1.0 \mathrm{M})$, final concentration is $0.5 \mu \mathrm{M}$. Top, full spectra; bottom, enlarged spectra. 

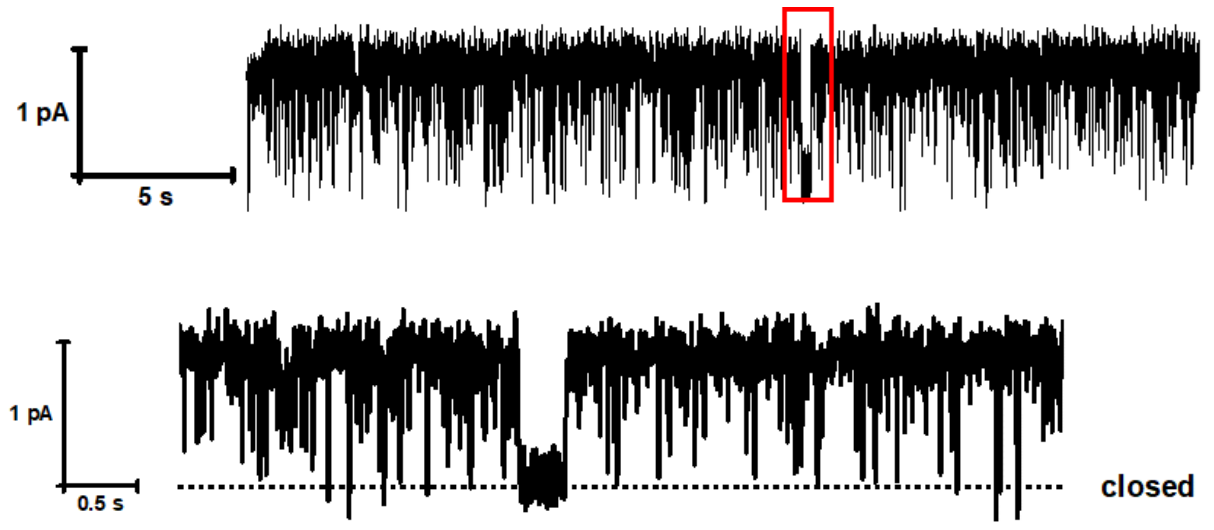

Figure S13. Current traces of channel molecule 1 at $60 \mathrm{mV}$ in symmetrical $\mathrm{KCl}$ solutions (cis/trans $=1.0 \mathrm{M} / 1.0 \mathrm{M}$ ), final concentration is $0.5 \mu \mathrm{M}$. Top, full spectra; bottom, enlarged spectra.

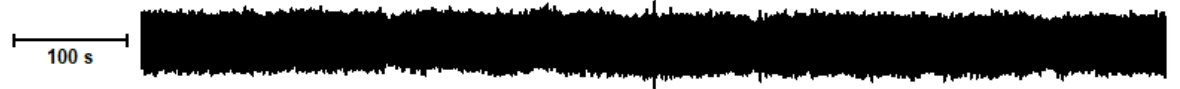

Figure S14. Current trace of channel molecule 1 at $0 \mathrm{mV}$ in symmetrical $\mathrm{KCl}$ solutions (cis/trans $=1.0 \mathrm{M} / 1.0 \mathrm{M})$, final concentration is $0.5 \mu \mathrm{M}$. Full spectra.
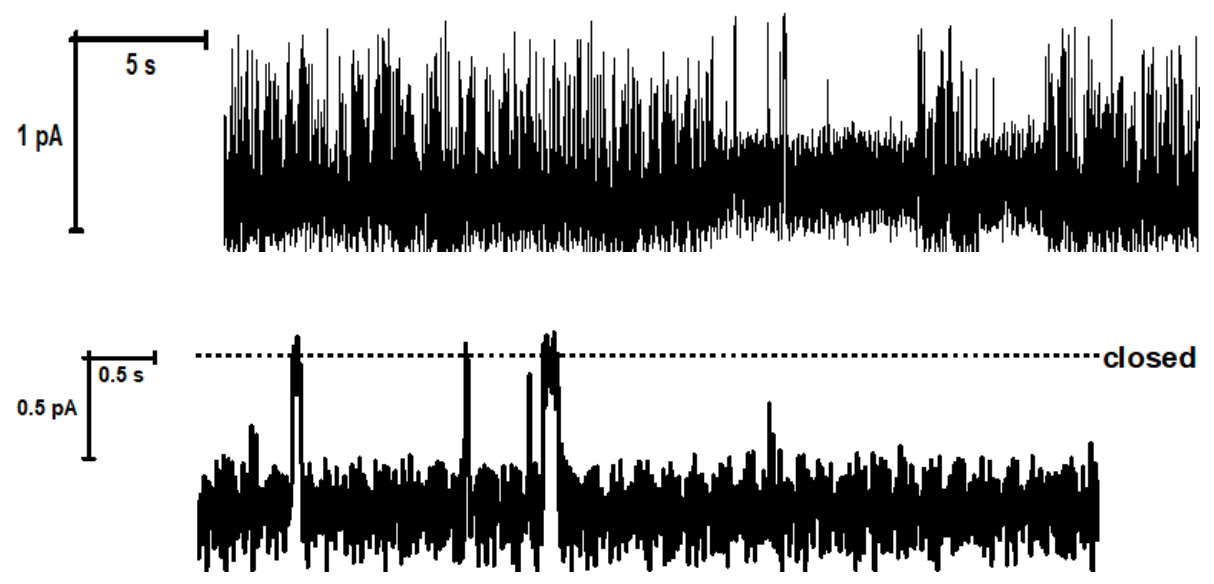

Figure S15. Current traces of channel molecule 1 at $-60 \mathrm{mV}$ in symmetrical $\mathrm{KCl}$ solutions $($ cis/trans $=1.0 \mathrm{M} / 1.0 \mathrm{M})$, final concentration is $0.5 \mu \mathrm{M}$. Top, full spectra; bottom, enlarged spectra. 

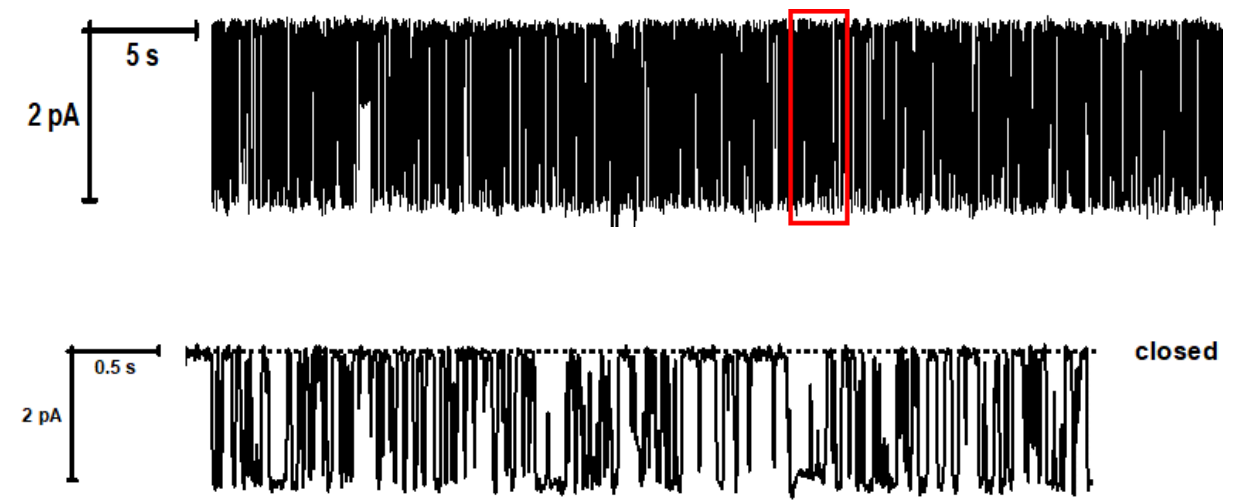

Figure S16. Current traces of channel molecule 1 at $-100 \mathrm{mV}$ in symmetrical $\mathrm{KCl}$ solutions (cis/trans $=1.0 \mathrm{M} / 1.0 \mathrm{M}$ ), final concentration is $0.5 \mu \mathrm{M}$. Top, full spectra; bottom, enlarged spectra.
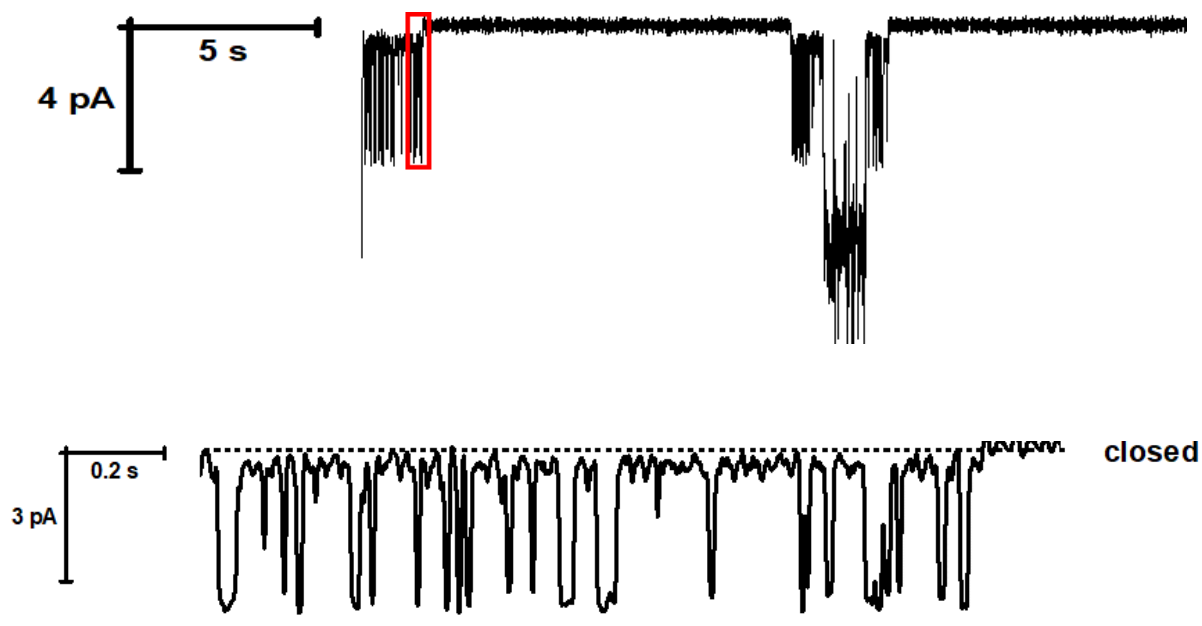

Figure S17. Current traces of channel molecule 1 at $-150 \mathrm{mV}$ in symmetrical $\mathrm{KCl}$ solutions (cis/trans $=1.0 \mathrm{M} / 1.0 \mathrm{M}$ ), final concentration is $0.5 \mu \mathrm{M}$. Top, full spectra; bottom, enlarged spectra. 
Table S3. The current under the corresponding voltage and slope conductance $g$ in symmetrical $\mathrm{KCl}$ solutions (cis/trans $=1.0 \mathrm{M} / 1.0 \mathrm{M}$, the final concentration of $\mathbf{1}$ is $0.5 \mu \mathrm{M})$.

\begin{tabular}{ccccccccc}
\hline & \multicolumn{7}{c}{ Current (pA) } & \\
\cline { 2 - 7 } Entry & 150 & 100 & 60 & 0 & -60 & -100 & -150 & $g(\mathrm{pS})$ \\
& $(\mathrm{mV})$ & $(\mathrm{mV})$ & $(\mathrm{mV})$ & $(\mathrm{mV})$ & $\begin{array}{c}\mathrm{mV}) \\
(\mathrm{mV})\end{array}$ & $(\mathrm{mV})$ & \\
\hline 1 & 3.04 & 2.04 & 0.82 & 0 & -0.79 & -1.94 & -3.20 & $19.8 \pm 1.0$ \\
2 & 3.18 & 1.96 & 0.79 & 0 & -0.90 & -2.00 & -3.25 & $20.0 \pm 1.0$ \\
3 & 3.53 & 2.10 & 0.79 & 0 & -0.81 & -2.31 & -3.36 & $21.7 \pm 1.0$ \\
4 & - & 1.77 & 1.02 & 0 & -0.80 & -1.94 & -3.05 & $18.7 \pm 1.0$ \\
5 & 3.14 & 2.0 & 0.70 & 0 & -0.94 & -2.18 & -3.77 & $21.5 \pm 1.0$ \\
6 & 3.60 & 2.01 & 1.02 & 0 & -1.22 & -2.19 & -3.78 & $23.0 \pm 1.0$ \\
\hline
\end{tabular}

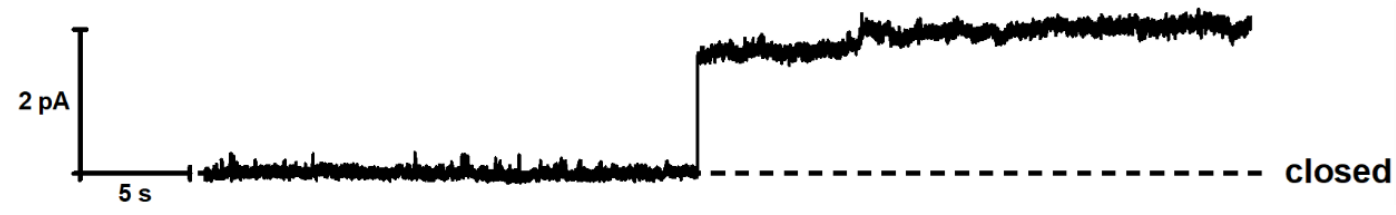

Figure S18. Current trace of channel molecule 1 at $100 \mathrm{mV}$ in symmetrical $\mathrm{KCl}$ solutions (cis/trans $=1.0 \mathrm{M} / 1.0 \mathrm{M})$, final concentration is $0.05 \mu \mathrm{M}$. Full spectra.

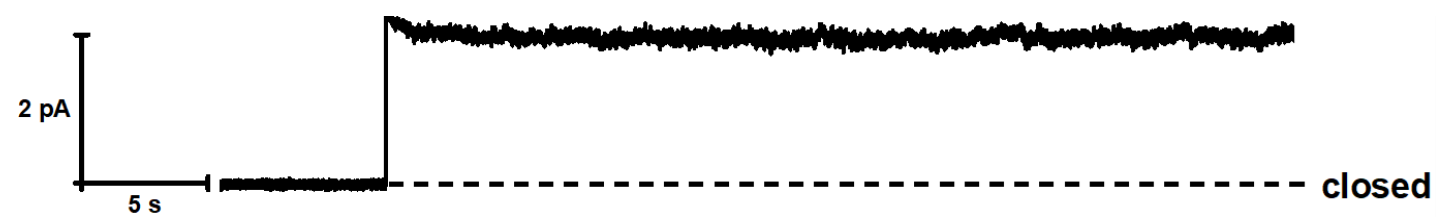

Figure S19. Current trace of channel molecule 1 at $80 \mathrm{mV}$ in symmetrical $\mathrm{KCl}$ solutions (cis/trans $=1.0 \mathrm{M} / 1.0 \mathrm{M})$, final concentration is $0.05 \mu \mathrm{M}$. Full spectra. 


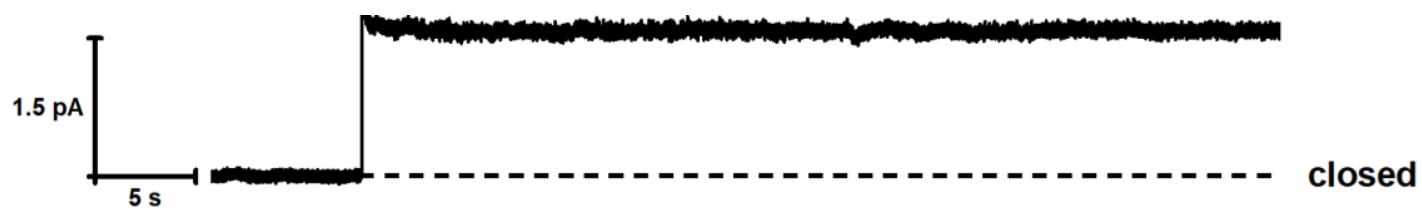

Figure S20. Current trace of channel molecule 1 at $60 \mathrm{mV}$ in symmetrical $\mathrm{KCl}$ solutions (cis/trans $=1.0 \mathrm{M} / 1.0 \mathrm{M}$ ), final concentration is $0.05 \mu \mathrm{M}$. Full spectra.

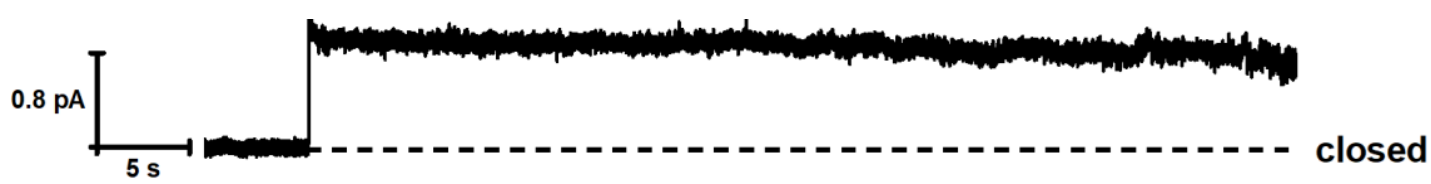

Figure S21. Current trace of channel molecule 1 at $40 \mathrm{mV}$ in symmetrical $\mathrm{KCl}$ solutions (cis/trans $=1.0 \mathrm{M} / 1.0 \mathrm{M})$, final concentration is $0.05 \mu \mathrm{M}$. Full spectra.

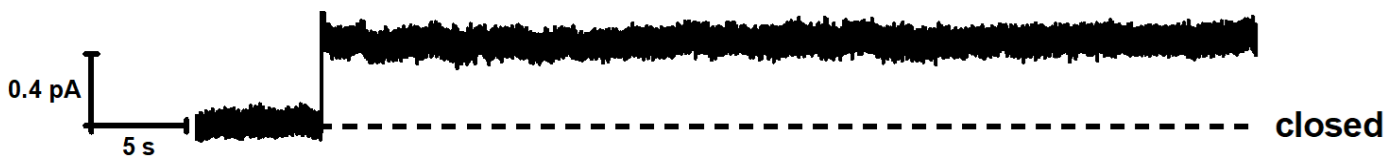

Figure S22. Current trace of channel molecule $\mathbf{1}$ at $20 \mathrm{mV}$ in symmetrical $\mathrm{KCl}$ solutions (cis/trans $=1.0 \mathrm{M} / 1.0 \mathrm{M}$ ), final concentration is $0.05 \mu \mathrm{M}$. Full spectra.

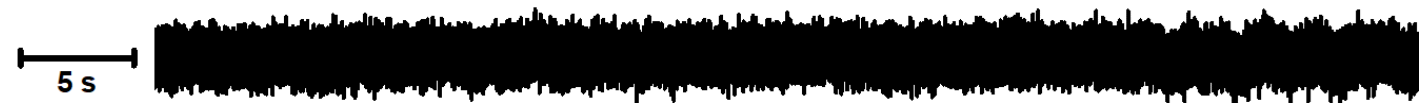

Figure S23. Current trace of channel molecule $\mathbf{1}$ at $0 \mathrm{mV}$ in symmetrical $\mathrm{KCl}$ solutions ( cis/trans $=1.0 \mathrm{M} / 1.0 \mathrm{M}$ ), final concentration is $0.05 \mu \mathrm{M}$. Full spectra.

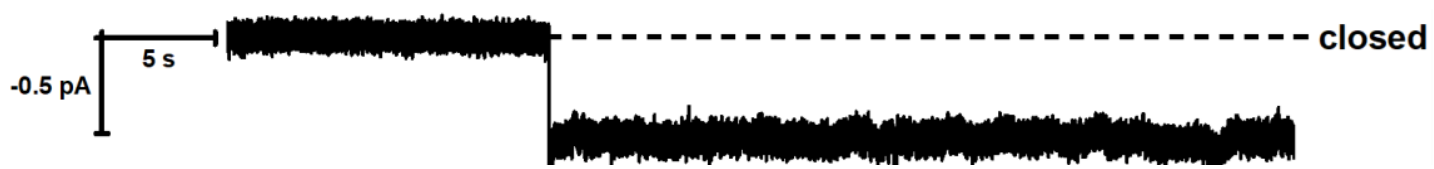

Figure S24. Current trace of channel molecule 1 at $-20 \mathrm{mV}$ in symmetrical $\mathrm{KCl}$ solutions (cis/trans $=1.0 \mathrm{M} / 1.0 \mathrm{M})$, final concentration is $0.05 \mu \mathrm{M}$. Full spectra. 


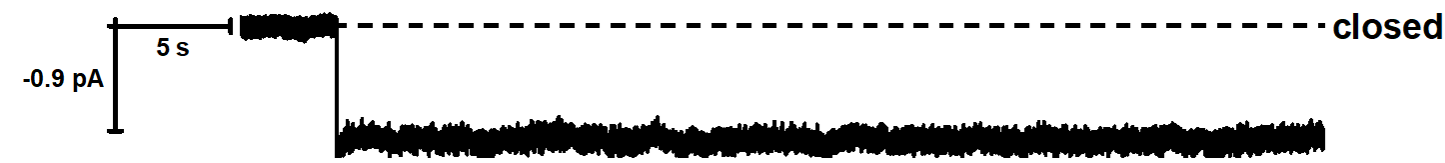

Figure S25. Current trace of channel molecule $\mathbf{1}$ at $-40 \mathrm{mV}$ in symmetrical $\mathrm{KCl}$ solutions $($ cis/trans $=1.0 \mathrm{M} / 1.0 \mathrm{M})$, final concentration is $0.05 \mu \mathrm{M}$. Full spectra.

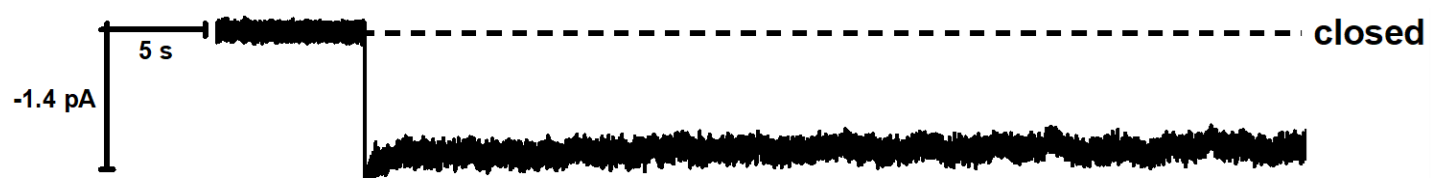

Figure S26. Current trace of channel molecule 1 at $-60 \mathrm{mV}$ in symmetrical $\mathrm{KCl}$ solutions (cis/trans $=1.0 \mathrm{M} / 1.0 \mathrm{M})$, final concentration is $0.05 \mu \mathrm{M}$. Full spectra.

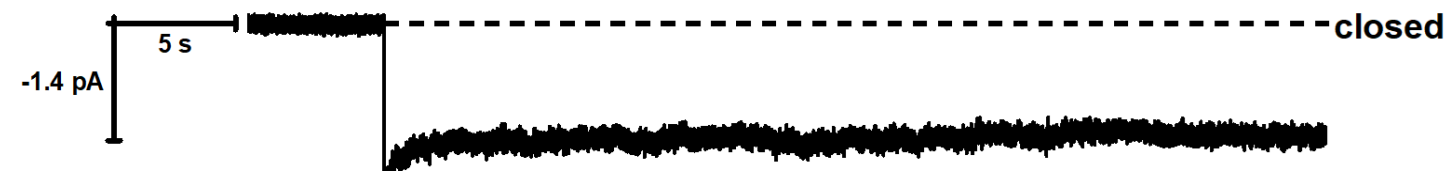

Figure S27. Current trace of channel molecule 1 at $-80 \mathrm{mV}$ in symmetrical $\mathrm{KCl}$ solutions $($ cis/trans $=1.0 \mathrm{M} / 1.0 \mathrm{M})$, final concentration is $0.05 \mu \mathrm{M}$. Full spectra.

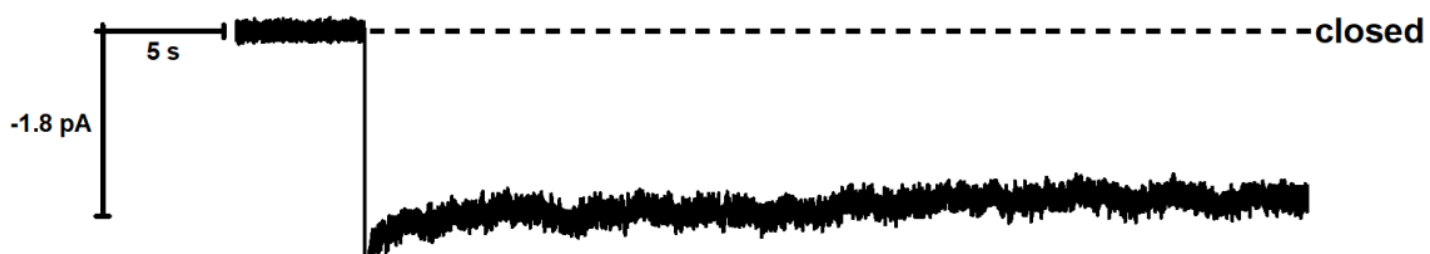

Figure S28. Current trace of channel molecule 1 at $-100 \mathrm{mV}$ in symmetrical $\mathrm{KCl}$ solutions (cis/trans $=1.0 \mathrm{M} / 1.0 \mathrm{M})$, final concentration is $0.05 \mu \mathrm{M}$. Full spectra. 
Table S4. The current under the corresponding voltage and slope conductance $g$ in symmetrical $\mathrm{KCl}$ solutions (cis/trans $=1.0 \mathrm{M} / 1.0 \mathrm{M}$, the final concentration of $\mathbf{1}$ is $0.05 \mu \mathrm{M})$.

\begin{tabular}{|c|c|c|c|c|c|c|c|c|c|c|c|c|}
\hline \multirow[b]{2}{*}{ Entry } & \multicolumn{11}{|c|}{ Current (pA) } & \multirow[b]{2}{*}{$\begin{array}{c}\mathrm{g} \\
(\mathrm{pS})\end{array}$} \\
\hline & $\begin{array}{c}100 \\
(\mathrm{mV})\end{array}$ & $\begin{array}{c}80 \\
(\mathrm{mV})\end{array}$ & $\begin{array}{c}60 \\
(\mathrm{mV})\end{array}$ & $\begin{array}{c}40 \\
(\mathrm{mV})\end{array}$ & $\begin{array}{c}20 \\
(\mathrm{mV})\end{array}$ & $\begin{array}{c}0 \\
(\mathrm{mV})\end{array}$ & $\begin{array}{c}-20 \\
(\mathrm{mV})\end{array}$ & $\begin{array}{c}-40 \\
(\mathrm{mV})\end{array}$ & $\begin{array}{c}-60 \\
(\mathrm{mV})\end{array}$ & $\begin{array}{c}-80 \\
(\mathrm{mV})\end{array}$ & $\begin{array}{l}-100 \\
(\mathrm{mV})\end{array}$ & \\
\hline 1 & 2.00 & 1.40 & 0.93 & 0.57 & 0.23 & 0 & -0.19 & -0.59 & -0.81 & -1.17 & -1.96 & $\begin{array}{c}17.2 \pm \\
2.2\end{array}$ \\
\hline 2 & 2.29 & 2.06 & 1.54 & 0.74 & 0.36 & 0 & -0.48 & -0.83 & -1.32 & -1.41 & -1.73 & $\begin{array}{c}21.1 \pm \\
2.2\end{array}$ \\
\hline 3 & 2.16 & 1.01 & - & - & - & 0 & -0.21 & -0.33 & -0.65 & -0.88 & -1.75 & $\begin{array}{c}16.0 \pm \\
2.7\end{array}$ \\
\hline
\end{tabular}

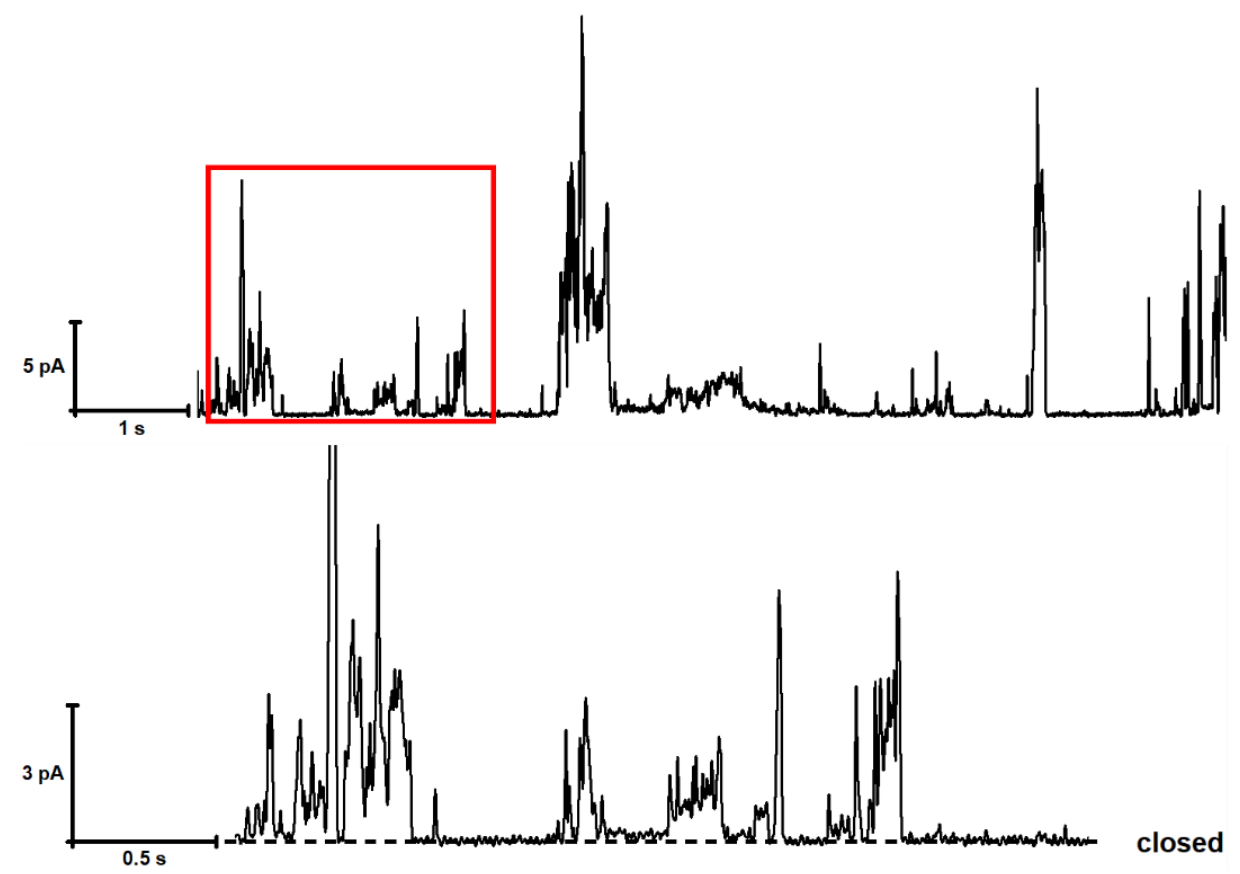

Figure S29. Current traces of channel molecule $\mathbf{1}$ at $150 \mathrm{mV}$ in symmetrical $\mathrm{KCl}$ solutions $($ cis/trans $=1.0 \mathrm{M} / 1.0 \mathrm{M})$, final concentration is $1.0 \mu \mathrm{M}$. Top, full spectra; bottom, enlarged spectra. 


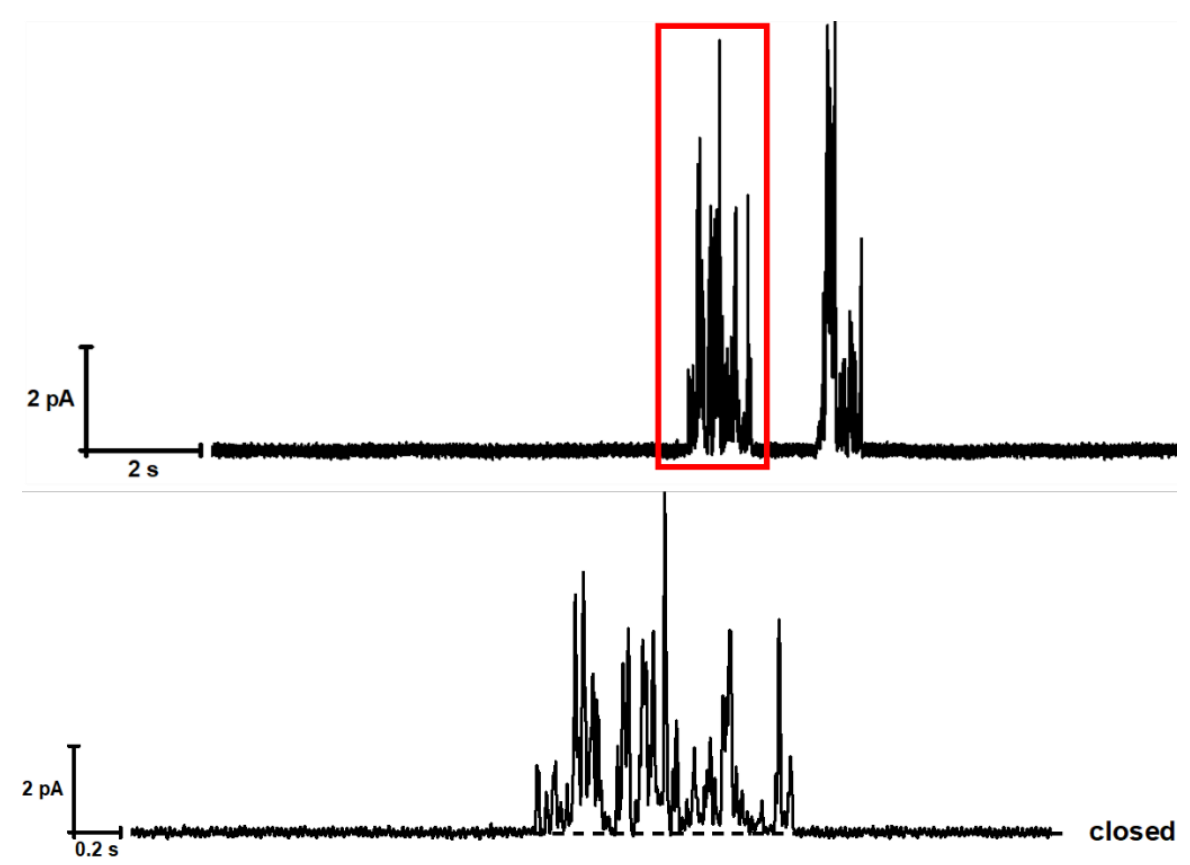

Figure S30. Current traces of channel molecule $\mathbf{1}$ at $100 \mathrm{mV}$ in symmetrical $\mathrm{KCl}$ solutions (cis/trans $=1.0 \mathrm{M} / 1.0 \mathrm{M}$ ), final concentration is $1.0 \mu \mathrm{M}$. Top, full spectra; bottom, enlarged spectra.

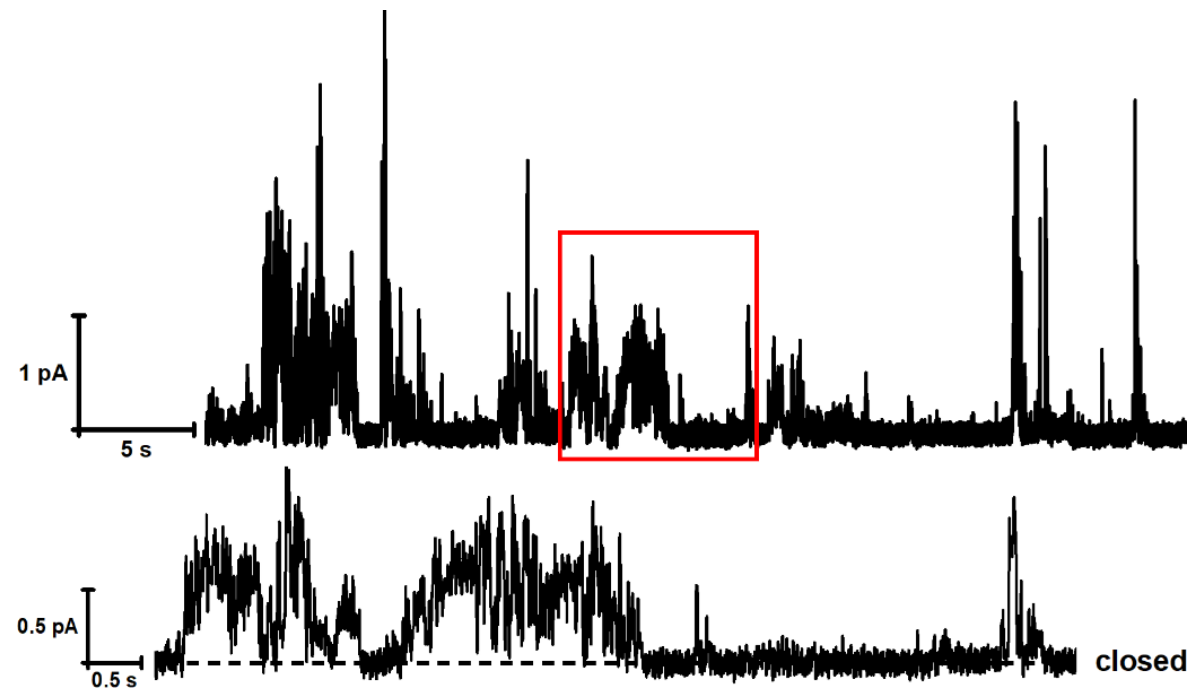

Figure S31. Current traces of channel molecule 1 at $60 \mathrm{mV}$ in symmetrical $\mathrm{KCl}$ solutions (cis/trans $=1.0 \mathrm{M} / 1.0 \mathrm{M}$ ), final concentration is $1.0 \mu \mathrm{M}$. Top, full spectra; bottom, enlarged spectra. 


\section{Tos}

Figure S32. Current trace of channel molecule 1 at $0 \mathrm{mV}$ in symmetrical $\mathrm{KCl}$ solutions ( cis/trans $=1.0 \mathrm{M} / 1.0 \mathrm{M})$, final concentration is $1.0 \mu \mathrm{M}$. Full spectra.

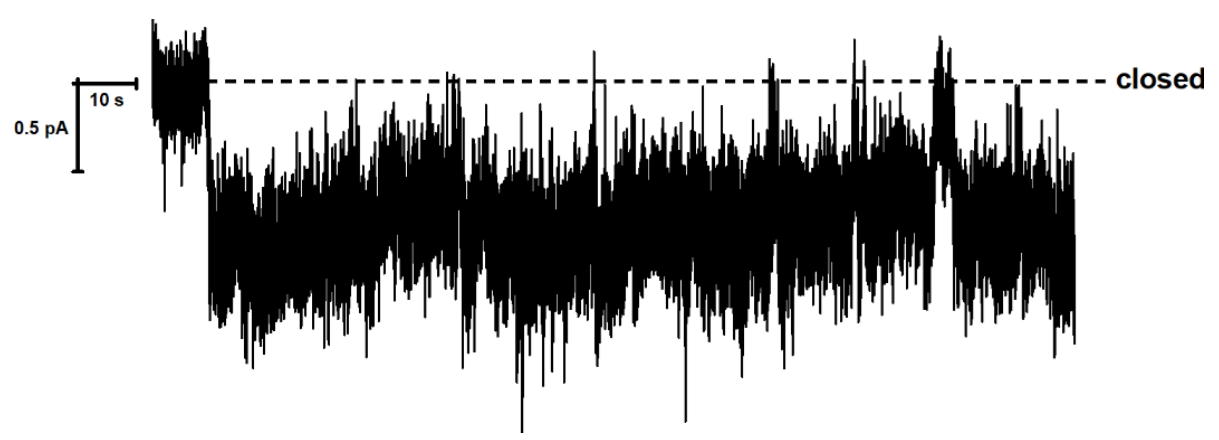

Figure S33. Current trace of channel molecule $\mathbf{1}$ at $-60 \mathrm{mV}$ in symmetrical $\mathrm{KCl}$ solutions ( cis/trans $=1.0 \mathrm{M} / 1.0 \mathrm{M})$, final concentration is $1.0 \mu \mathrm{M}$. Full spectra.

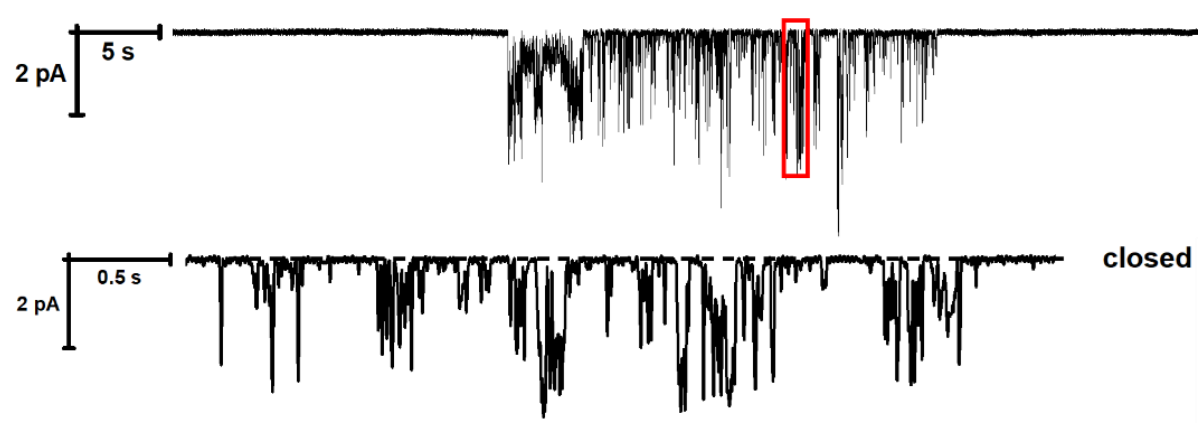

Figure S34. Current traces of channel molecule $\mathbf{1}$ at $-100 \mathrm{mV}$ in symmetrical $\mathrm{KCl}$ solutions (cis/trans $=1.0 \mathrm{M} / 1.0 \mathrm{M}$ ), final concentration is $1.0 \mu \mathrm{M}$. Top, full spectra; bottom, enlarged spectra. 


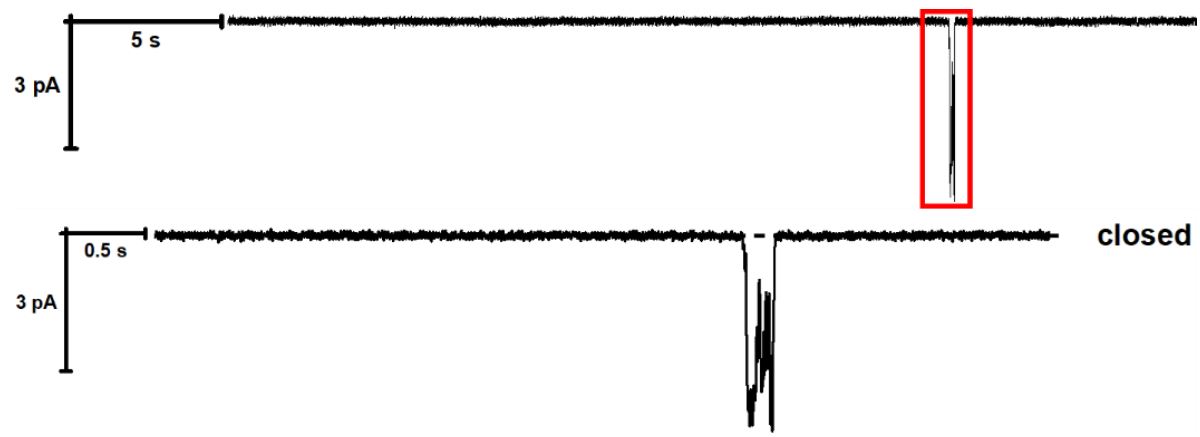

Figure S35. Current traces of channel molecule $\mathbf{1}$ at $-150 \mathrm{mV}$ in symmetrical $\mathrm{KCl}$ solutions $($ cis/trans $=1.0 \mathrm{M} / 1.0 \mathrm{M})$, final concentration is $1.0 \mu \mathrm{M}$. Top, full spectra; bottom, enlarged spectra.

Table S5. The current under the corresponding voltage and slope conductance $g$ in symmetrical $\mathrm{KCl}$ solutions (cis/trans $=1.0 \mathrm{M} / 1.0 \mathrm{M}$, the final concentration of $\mathbf{1}$ is $1.0 \mu \mathrm{M})$.

\begin{tabular}{ccccccccc}
\hline & \multicolumn{7}{c}{ Current (pA) } & \\
\cline { 2 - 8 } Entry & 150 & 100 & 60 & 0 & -60 & -100 & -150 & $g(\mathrm{pS})$ \\
& $(\mathrm{mV})$ & $(\mathrm{mV})$ & $(\mathrm{mV})$ & $(\mathrm{mV})$ & $(\mathrm{mV})$ & $(\mathrm{mV})$ & $(\mathrm{mV})$ & \\
\hline 1 & 3.28 & 2.09 & 0.79 & 0 & -0.88 & -2.00 & -3.39 & $20.9 \pm 1.1$ \\
2 & 3.10 & 1.86 & 0.73 & 0 & -0.81 & -1.92 & -3.01 & $19.2 \pm 1.0$ \\
3 & 3.09 & 2.07 & 0.67 & 0 & - & -2.21 & -3.02 & $20.2 \pm 1.0$ \\
\hline
\end{tabular}




\section{Ion selectivity study by planar lipid bilayer experiments}

Conditions for anion/cation selectivity experiments were that: cis chamber $1.0 \mathrm{M}$ $\mathrm{KCl}$ aqueous solution $(1 \mathrm{~mL})$, trans chamber $0.5 \mathrm{M}$ or $0.25 \mathrm{M} \mathrm{KCl}$ aqueous solution ( $1 \mathrm{~mL}$ ); holding potentials changing between $-100 \mathrm{mV}$ and $+100 \mathrm{mV}$; the final concentration of 1 is $0.5 \mu \mathrm{M}$.

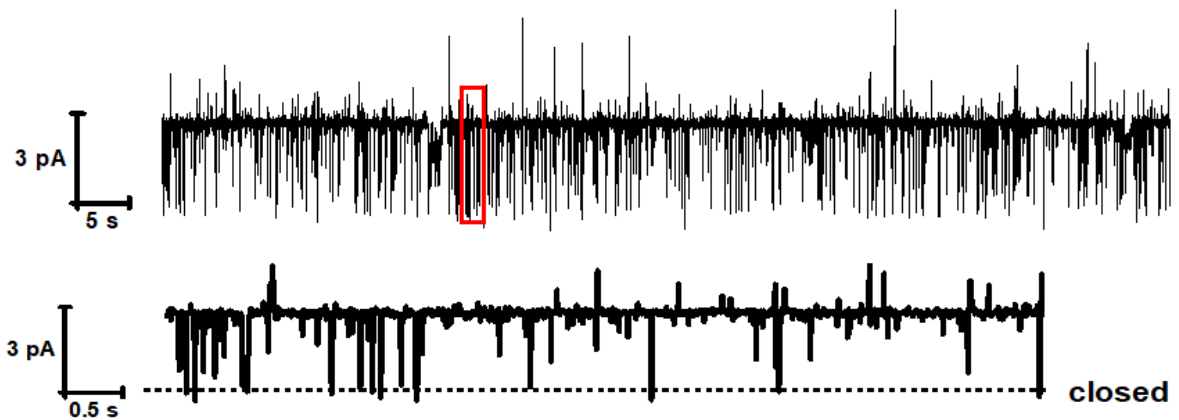

Figure S36. Current traces of channel molecule 1 at $100 \mathrm{mV}$ in $\mathrm{KCl}$ solutions (cis/trans $=1.0 \mathrm{M} / 0.25 \mathrm{M}$ ). Top, full spectra; bottom, enlarged spectra.

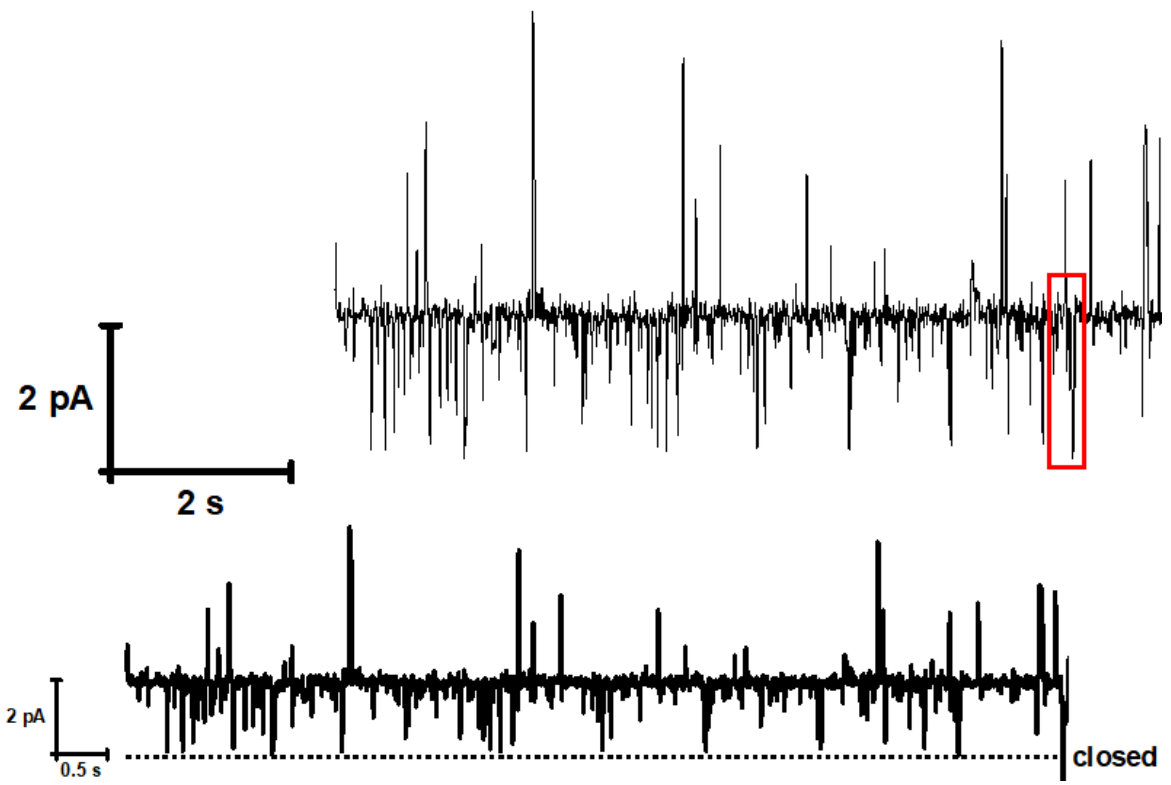

Figure S37. Current traces of channel molecule 1 at $60 \mathrm{mV}$ in $\mathrm{KCl}$ solutions (cis/trans $=1.0 \mathrm{M} / 0.25 \mathrm{M})$. Top, full spectra; bottom, enlarged spectra. 


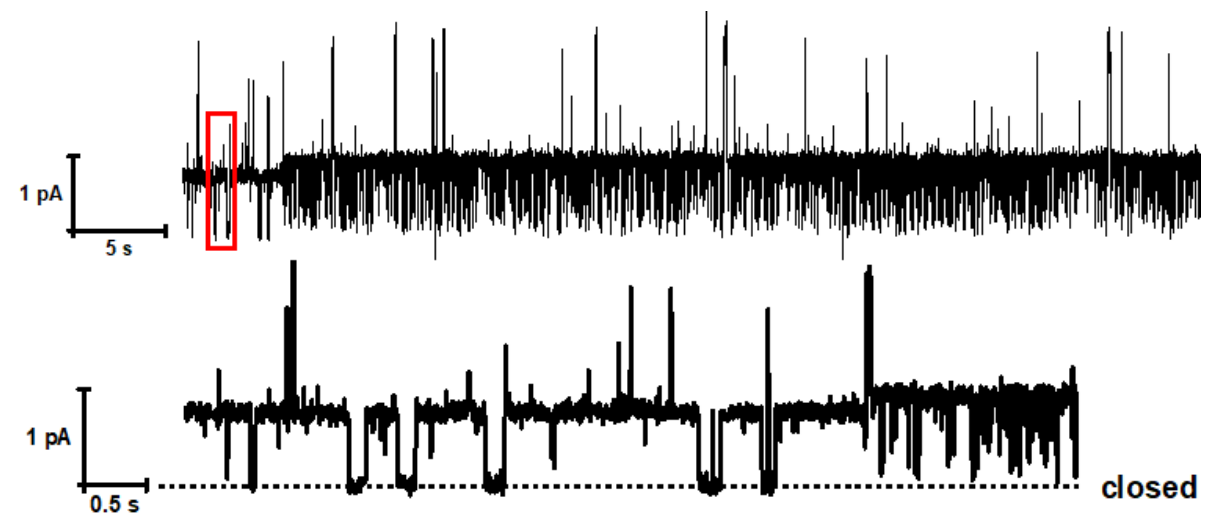

Figure S38. Current traces of channel molecule $\mathbf{1}$ at $20 \mathrm{mV}$ in $\mathrm{KCl}$ solutions (cis/trans $=1.0 \mathrm{M} / 0.25 \mathrm{M}$ ). Top, full spectra; bottom, enlarged spectra.

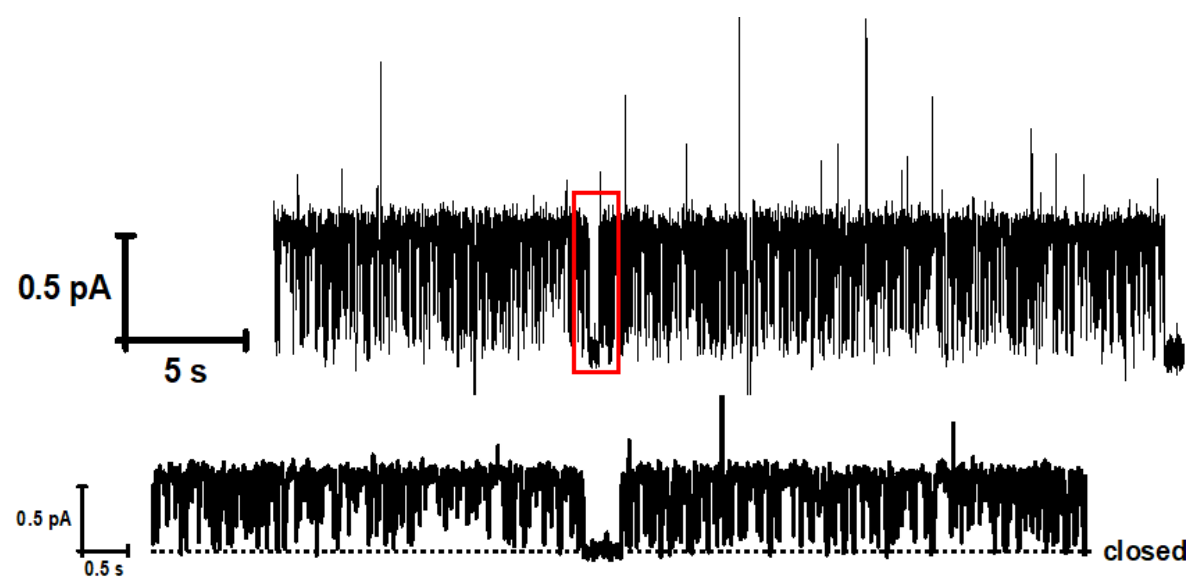

Figure S39. Current traces of channel molecule 1 at $0 \mathrm{mV}$ in $\mathrm{KCl}$ solutions (cis/trans $=1.0 \mathrm{M} / 0.25 \mathrm{M})$. Top, full spectra; bottom, enlarged spectra.

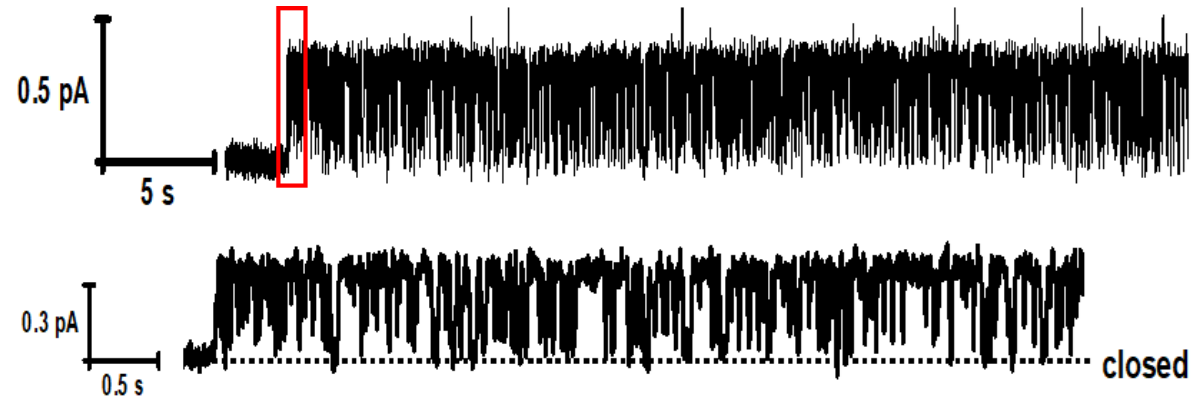

Figure S40. Current traces of channel molecule $\mathbf{1}$ at $-20 \mathrm{mV}$ in $\mathrm{KCl}$ solutions (cis/trans $=1.0 \mathrm{M} / 0.25 \mathrm{M})$. Top, full spectra; bottom, enlarged spectra. 


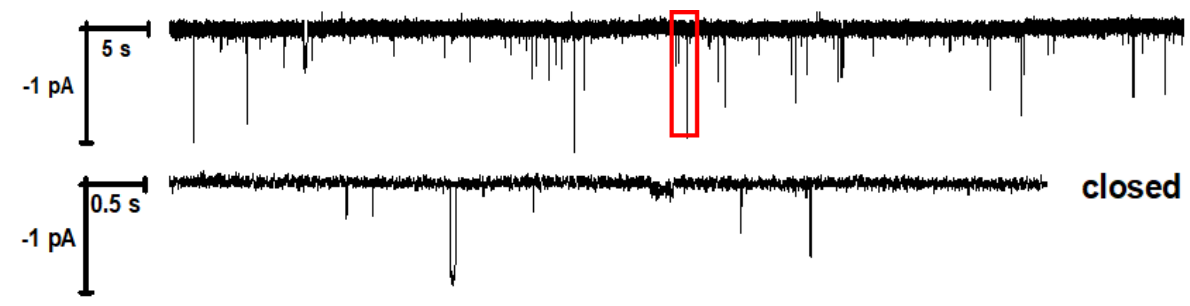

Figure S41. Current traces of channel molecule 1 at $-60 \mathrm{mV}$ in $\mathrm{KCl}$ solutions ( cis/trans $=1.0 \mathrm{M} / 0.25 \mathrm{M})$. Top, full spectra; bottom, enlarged spectra.

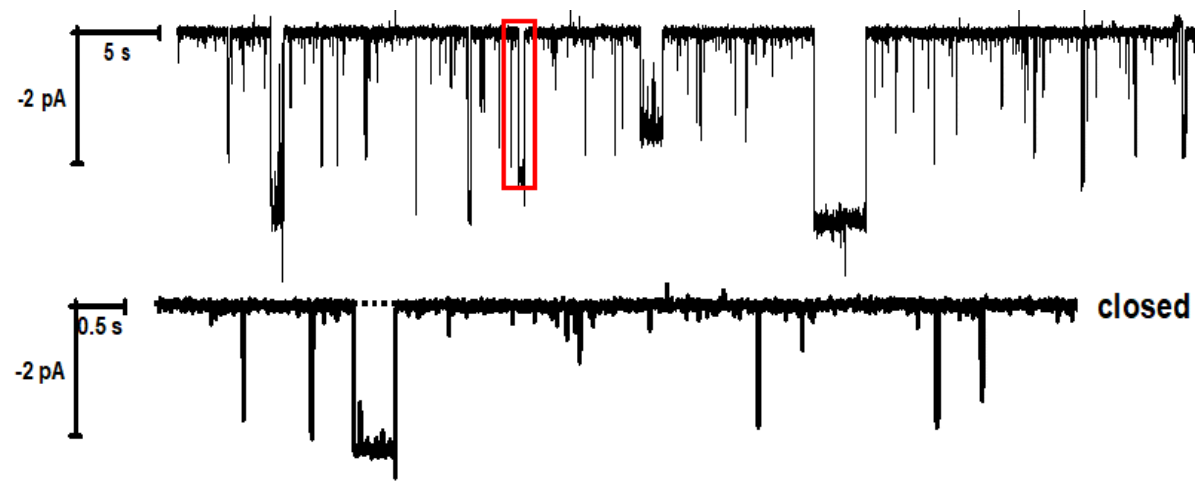

Figure S42. Current traces of channel molecule 1 at $-100 \mathrm{mV}$ in $\mathrm{KCl}$ solutions (cis/trans $=1.0 \mathrm{M} / 0.25 \mathrm{M}$ ). Top, full spectra; bottom, enlarged spectra.

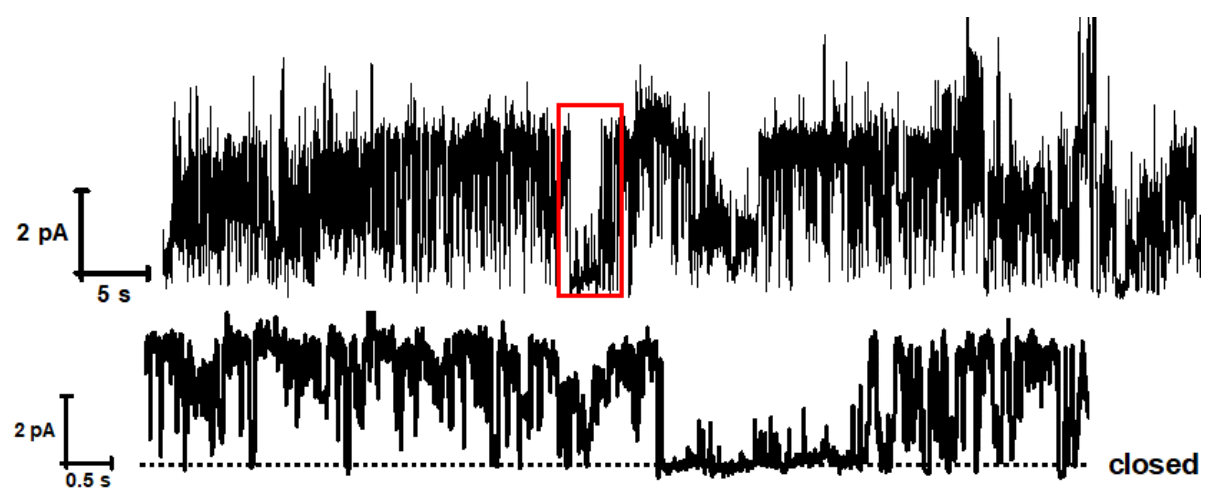

Figure S43. Current traces of channel molecule 1 at $100 \mathrm{mV}$ in $\mathrm{KCl}$ solutions $($ cis/trans $=1.0 \mathrm{M} / 0.5 \mathrm{M})$. Top, full spectra; bottom, enlarged spectra. 


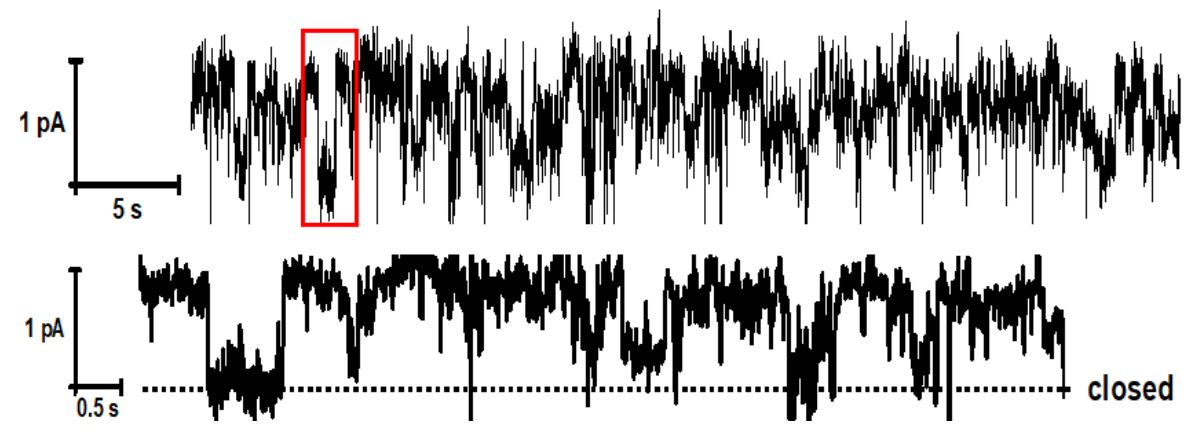

Figure S44. Current traces of channel molecule 1 at $20 \mathrm{mV}$ in $\mathrm{KCl}$ solutions (cis/trans $=1.0 \mathrm{M} / 0.5 \mathrm{M})$. Top, full spectra; bottom, enlarged spectra.

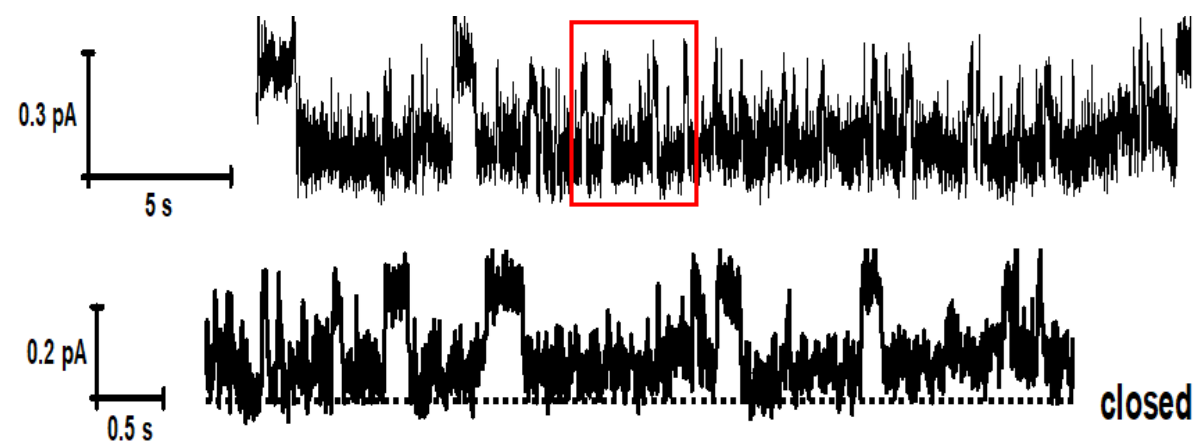

Figure S45. Current traces of channel molecule 1 at $0 \mathrm{mV}$ in $\mathrm{KCl}$ solutions (cis/trans $=1.0 \mathrm{M} / 0.5 \mathrm{M})$. Top, full spectra; bottom, enlarged spectra.

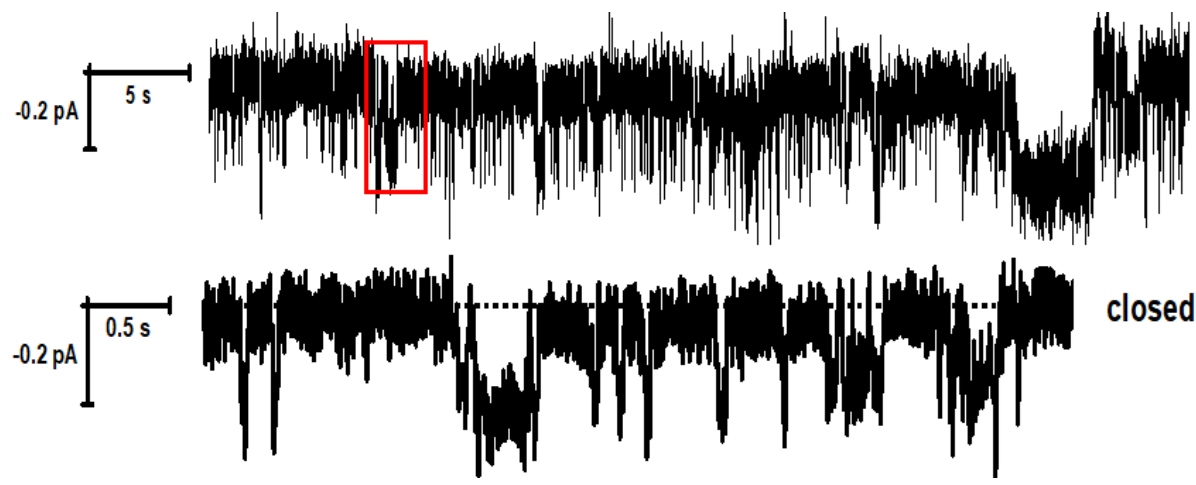

Figure S46. Current traces of channel molecule 1 at $-20 \mathrm{mV}$ in $\mathrm{KCl}$ solutions (cis/trans $=1.0 \mathrm{M} / 0.5 \mathrm{M}$ ). Top, full spectra; bottom, enlarged spectra. 


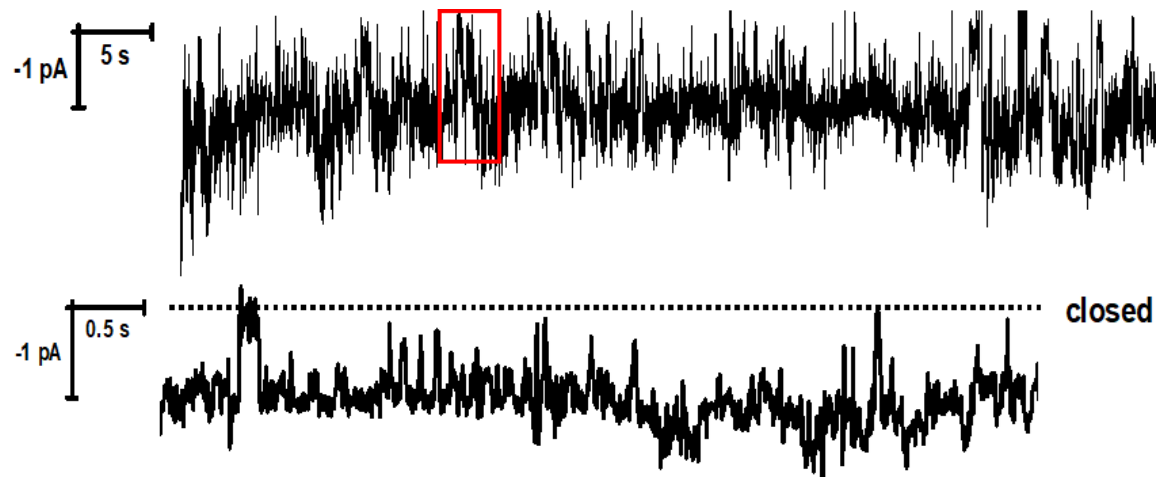

Figure S47. Current traces of channel molecule 1 at $-60 \mathrm{mV}$ in $\mathrm{KCl}$ solutions (cis/trans $=1.0 \mathrm{M} / 0.5 \mathrm{M})$. Top, full spectra; bottom, enlarged spectra.

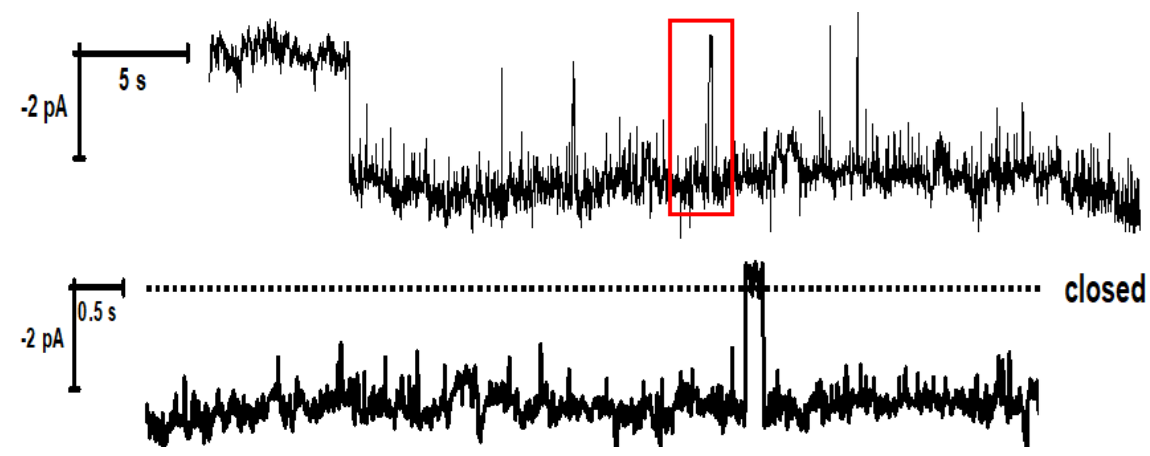

Figure S48. Current traces of channel molecule $\mathbf{1}$ at $-100 \mathrm{mV}$ in $\mathrm{KCl}$ solutions (cis/trans $=1.0 \mathrm{M} / 0.5 \mathrm{M}$ ). Top, full spectra; bottom, enlarged spectra.

Table S6. Reversal voltage $\mathrm{V}_{\mathrm{r}}$ and permeability ratio $P_{\mathrm{Cl}}-P_{\mathrm{K}}{ }^{+}$.

\begin{tabular}{ccccc}
\hline & \multicolumn{2}{c}{ cis/trans=1.0 M/0.25 M KCl } & \multicolumn{2}{c}{ cis/trans=1.0 M/0.5 M KCl } \\
\cline { 2 - 5 } Entry & $\begin{array}{c}\text { Reversal voltage } \\
\mathrm{V}_{\mathrm{r}}(\mathrm{mV})^{\mathrm{a}}\end{array}$ & $P_{\mathrm{Cl}-}{ }^{-P_{\mathrm{K}+}^{\mathrm{b}}}$ & $\begin{array}{c}\text { Reversal voltage } \\
\mathrm{V}_{\mathrm{r}}(\mathrm{mV})^{\mathrm{a}}\end{array}$ & $P_{\mathrm{Cl}-} / P_{\mathrm{K}+}^{\mathrm{b}}$ \\
\hline 1 & 12.89 & 2.38 & 4.12 & 1.63 \\
2 & 10.12 & 1.95 & 4.48 & 1.70 \\
3 & 12.47 & 2.31 & 4.72 & 1.75 \\
4 & 8.78 & 1.78 & 5.22 & 1.87 \\
5 & 7.11 & 1.59 & 4.52 & 1.71 \\
6 & 7.54 & 1.64 & 4.21 & 1.64 \\
\hline
\end{tabular}


a, obtained after correcting the potential caused by chloride concentration gradient; $b$, calculated from the equation derived from Goldman-Hodgin-Katz equation:

$$
P_{\mathrm{Cl}}-P_{\mathrm{K}}{ }^{+}=\left[a_{\mathrm{K}, \text { cis }}-a_{\mathrm{K}, \text { trans }} \exp \left(-\mathrm{V}_{\mathrm{r}} \mathrm{F} / \mathrm{RT}\right)\right] /\left[a_{\mathrm{Cl}, \text { cis }} \exp \left(-\mathrm{V}_{\mathrm{r}} \mathrm{F} / \mathrm{RT}\right)-a_{\mathrm{Cl}, \text { trans }}\right]
$$

where $a_{\mathrm{K}, \text { cis }}$ and $a_{\mathrm{K} \text {, trans }}$ are the activities of $\mathrm{K}^{+}$in the cis and the trans chambers, $a_{\mathrm{Cl} \text {, cis }}$ and $a_{\mathrm{Cl}, \text { trans }}$ the same for $\mathrm{Cl}^{-}$.

Conditions for anion/anion selectivity experiments were that: cis chamber $1.0 \mathrm{M}$ $\mathrm{KCl}$ aqueous solution $(1 \mathrm{~mL})$, trans chamber $1.0 \mathrm{M} \mathrm{KBr}$ aqueous solution $(1 \mathrm{~mL})$; holding potentials changing between $-100 \mathrm{mV}$ and $+200 \mathrm{mV}$; the final concentration of 1 is $0.5 \mu \mathrm{M}$.

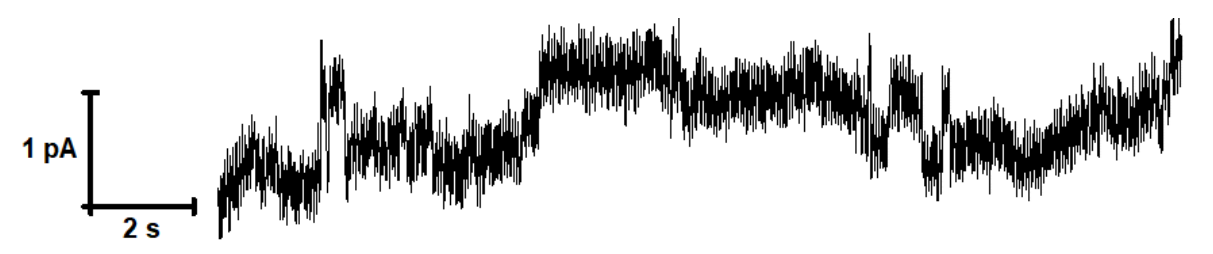

Figure S49. Current traces of channel molecule 1 at $200 \mathrm{mV}$ in $\mathrm{KCl}$ and $\mathrm{KBr}$ solutions (cis/trans $=1.0 \mathrm{M} \mathrm{KCl} / 1.0 \mathrm{M} \mathrm{KBr})$.

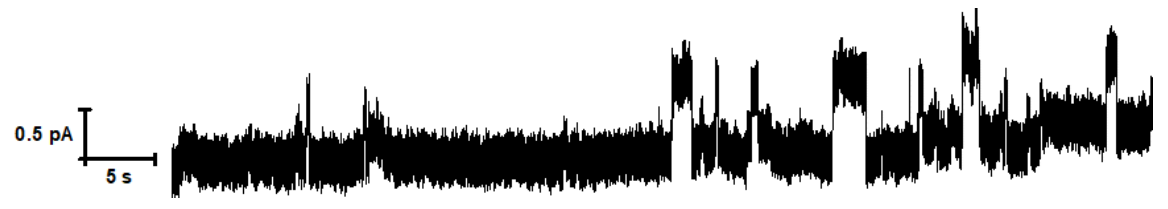

Figure S50. Current traces of channel molecule 1 at $150 \mathrm{mV}$ in $\mathrm{KCl}$ and $\mathrm{KBr}$ solutions (cis/trans $=1.0 \mathrm{M} \mathrm{KCl} / 1.0 \mathrm{M} \mathrm{KBr}$ ). 


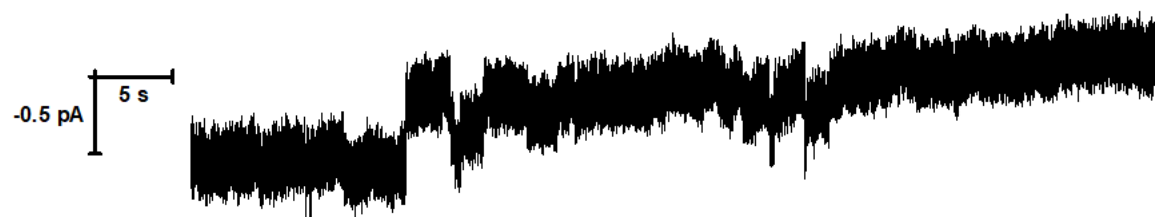

Figure S51. Current traces of channel molecule 1 at $50 \mathrm{mV}$ in $\mathrm{KCl}$ and $\mathrm{KBr}$ solutions (cis/trans $=1.0 \mathrm{M} \mathrm{KCl} / 1.0 \mathrm{M} \mathrm{KBr}$ ).

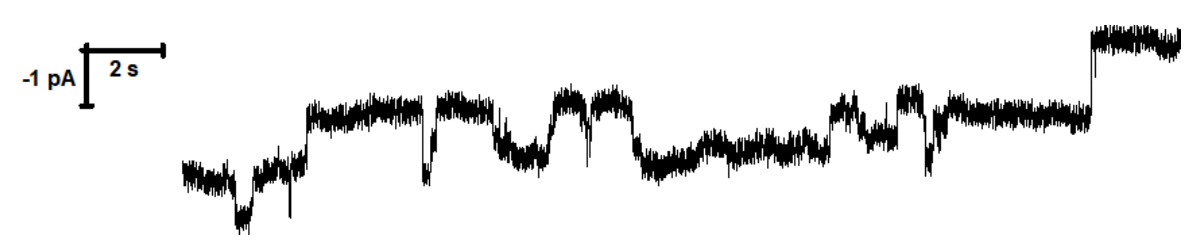

Figure S52. Current traces of channel molecule $\mathbf{1}$ at $0 \mathrm{mV}$ in $\mathrm{KCl}$ and $\mathrm{KBr}$ solutions (cis/trans $=1.0 \mathrm{M} \mathrm{KCl} / 1.0 \mathrm{M} \mathrm{KBr})$.

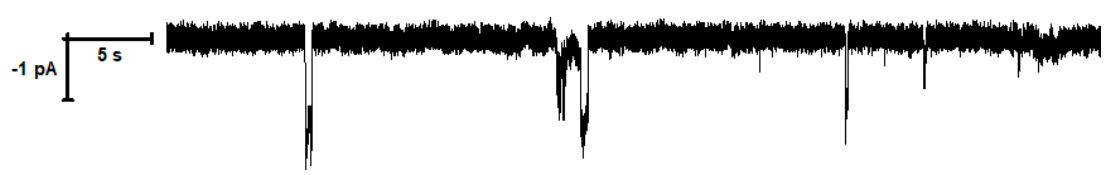

Figure S53. Current traces of channel molecule 1 at $-50 \mathrm{mV}$ in $\mathrm{KCl}$ and $\mathrm{KBr}$ solutions ( cis/trans $=1.0 \mathrm{M} \mathrm{KCl} / 1.0 \mathrm{M} \mathrm{KBr}$ ).

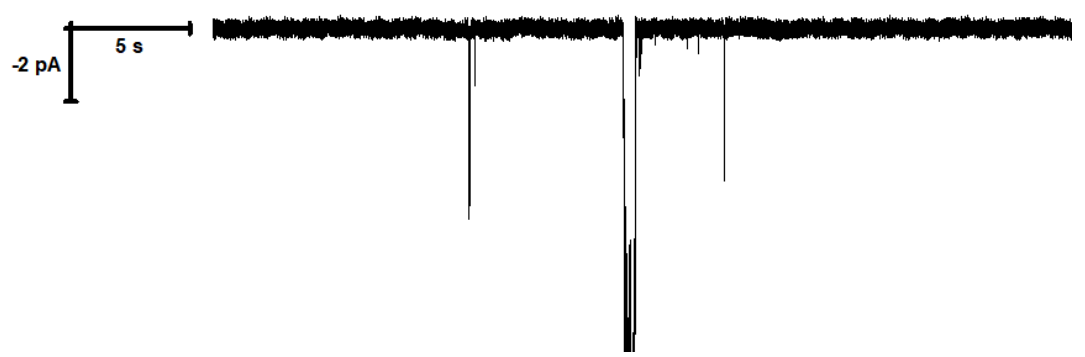

Figure S54. Current traces of channel molecule 1 at $-100 \mathrm{mV}$ in $\mathrm{KCl}$ and $\mathrm{KBr}$ solutions ( cis/trans $=1.0 \mathrm{M} \mathrm{KCl} / 1.0 \mathrm{M} \mathrm{KBr})$. 
Table S7. Reversal voltage $\mathrm{V}_{\mathrm{r}}$ and permeability ratio $P_{\mathrm{Cl}}{ }^{-} / P_{\mathrm{Br}}{ }^{-}$.

\begin{tabular}{ccc}
\hline \multirow{2}{*}{ Entry } & \multicolumn{2}{c}{ cis/trans $=1.0 \mathrm{M} \mathrm{KCl} / 1.0 \mathrm{M} \mathrm{KBr}$} \\
\cline { 2 - 3 } & Reversal voltage $\mathrm{V}_{\mathrm{r}}(\mathrm{mV})$ & $P_{\mathrm{Cl}-}{ }^{2}{ }_{\mathrm{Br}-}{ }^{\mathrm{a}}$ \\
\hline 1 & 78.62 & 21.32 \\
3 & 79.36 & 21.94 \\
4 & 83.06 & 25.34 \\
5 & 81.08 & 23.46 \\
6 & 81.64 & 23.98 \\
7 & 80.35 & 22.81 \\
\hline
\end{tabular}

a, calculated from: $V_{\mathrm{r}}=\left\{\mathrm{RT} \ln \left(P_{\mathrm{A}}[\mathrm{A}] / P_{\mathrm{B}}[\mathrm{B}]\right)\right\} / \mathrm{zF}$ 


\section{Calculation}

Geometry optimizations were carried out with the Accelrys Material Studio 7.0 suite by $\mathrm{DMol}^{3}$ code at LDA PWC/DNP level, and the orbital cut off was set at fine quality. A self-consistent field procedure was performed with a convergence criterion of $10^{-6} \mathrm{Ha}$. We calculated Frequency analysis and electrostatic potential using DFT method based on B3LYP/6-31G level.

Cartesian coordinates $(\AA)$ of the optimized structure.

\begin{tabular}{|c|c|c|c|}
\hline $\mathrm{C}$ & -1.08 & -1.2194 & -6.3151 \\
\hline $\mathrm{C}$ & -0.9976 & 0.1535 & -6.364 \\
\hline $\mathrm{C}$ & 0.0511 & 0.8394 & -5.784 \\
\hline $\mathrm{C}$ & 1.0073 & 0.1233 & -5.0924 \\
\hline $\mathrm{C}$ & 0.9387 & -1.2489 & -4.9812 \\
\hline $\mathrm{C}$ & -0.108 & -1.916 & -5.6078 \\
\hline $\mathrm{O}$ & -1.9891 & 0.8939 & -6.9869 \\
\hline $\mathrm{O}$ & 2.0568 & 0.8409 & -4.5361 \\
\hline $\mathrm{C}$ & 1.932 & 1.1848 & -3.2483 \\
\hline $\mathrm{C}$ & -2.9523 & 1.3374 & -6.1641 \\
\hline $\mathrm{N}$ & -3.7493 & 2.2605 & -6.6575 \\
\hline $\mathrm{N}$ & -4.8194 & 2.2534 & -4.5344 \\
\hline $\mathrm{C}$ & -3.9656 & 1.3031 & -4.193 \\
\hline $\mathrm{N}$ & -2.9907 & 0.8215 & -4.9406 \\
\hline $\mathrm{N}$ & 0.9236 & 0.678 & -2.5633 \\
\hline $\mathrm{C}$ & 0.9141 & 1.0406 & -1.2863 \\
\hline $\mathrm{N}$ & 1.7699 & 1.8381 & -0.6848 \\
\hline $\mathrm{N}$ & 2.8488 & 2.0194 & -2.7911 \\
\hline $\mathrm{O}$ & -4.1206 & 0.807 & -2.9586 \\
\hline $\mathrm{C}$ & -3.0855 & 0.02 & -2.475 \\
\hline $\mathrm{O}$ & -0.077 & 0.5624 & -0.5188 \\
\hline $\mathrm{C}$ & -3.0357 & -1.3357 & -2.7187 \\
\hline $\mathrm{C}$ & -1.9936 & -2.0722 & -2.1667 \\
\hline $\mathrm{C}$ & -1.0101 & -1.4587 & -1.4012 \\
\hline $\mathrm{C}$ & -1.078 & -0.0972 & -1.213 \\
\hline $\mathrm{C}$ & -2.1193 & 0.6538 & -1.7192 \\
\hline $\mathrm{C}$ & 6.3713 & 10.314 & -2.8816 \\
\hline $\mathrm{C}$ & 6.0739 & 11.7422 & -3.0999 \\
\hline $\mathrm{C}$ & 4.836 & 11.8446 & -3.7131 \\
\hline $\mathrm{C}$ & 4.2988 & 10.4797 & -3.9041 \\
\hline $\mathrm{C}$ & 6.868 & 12.8379 & -2.8642 \\
\hline $\mathrm{C}$ & 6.3924 & 14.0864 & -3.2682 \\
\hline
\end{tabular}




\begin{tabular}{|c|c|c|c|}
\hline $\mathrm{C}$ & 5.1399 & 14.1867 & -3.8765 \\
\hline $\mathrm{C}$ & 4.3418 & 13.0697 & -4.1009 \\
\hline $\mathrm{O}$ & 3.26 & 10.1259 & -4.4196 \\
\hline $\mathrm{O}$ & 7.3574 & 9.7968 & -2.4032 \\
\hline $\mathrm{O}$ & 3.5243 & 3.1865 & -0.9355 \\
\hline $\mathrm{C}$ & 4.3857 & 3.9631 & -1.7642 \\
\hline $\mathrm{C}$ & 3.9608 & 5.3987 & -1.6217 \\
\hline $\mathrm{O}$ & 4.699 & 6.1507 & -2.5402 \\
\hline $\mathrm{C}$ & 4.5024 & 7.5275 & -2.3821 \\
\hline $\mathrm{C}$ & 5.24 & 8.1973 & -3.5109 \\
\hline $\mathrm{C}$ & 2.7009 & 2.3198 & -1.5039 \\
\hline $\mathrm{C}$ & 5.5033 & 16.6275 & -2.0316 \\
\hline $\mathrm{C}$ & 6.5095 & 16.6099 & -3.0011 \\
\hline $\mathrm{C}$ & 6.8616 & 17.7915 & -3.6531 \\
\hline $\mathrm{C}$ & 6.1958 & 18.9405 & -3.3019 \\
\hline $\mathrm{C}$ & 5.2051 & 18.9559 & -2.335 \\
\hline $\mathrm{C}$ & 4.8369 & 17.798 & -1.6866 \\
\hline $\mathrm{C}$ & 6.4094 & 20.3189 & -3.7777 \\
\hline $\mathrm{N}$ & 5.4924 & 21.0971 & -3.0767 \\
\hline $\mathrm{C}$ & 4.7521 & 20.352 & -2.1599 \\
\hline $\mathrm{O}$ & 3.9295 & 20.8097 & -1.3965 \\
\hline $\mathrm{O}$ & 7.2037 & 20.7419 & -4.5901 \\
\hline $\mathrm{C}$ & 5.5108 & 22.5276 & -3.1034 \\
\hline $\mathrm{C}$ & -7.6548 & 10.8706 & -3.1872 \\
\hline $\mathrm{C}$ & -7.6397 & 12.2659 & -3.6677 \\
\hline $\mathrm{C}$ & -6.6633 & 12.3837 & -4.642 \\
\hline $\mathrm{C}$ & -6.0134 & 11.0664 & -4.809 \\
\hline $\mathrm{C}$ & -8.4348 & 13.3226 & -3.2934 \\
\hline $\mathrm{C}$ & -8.2288 & 14.5456 & -3.9329 \\
\hline $\mathrm{C}$ & -7.2481 & 14.6574 & -4.9211 \\
\hline $\mathrm{C}$ & -6.4489 & 13.5806 & -5.2877 \\
\hline $\mathrm{O}$ & -5.1048 & 10.746 & -5.5462 \\
\hline $\mathrm{O}$ & -8.3526 & 10.3582 & -2.3399 \\
\hline $\mathrm{O}$ & -5.3553 & 3.736 & -6.1839 \\
\hline $\mathrm{C}$ & -6.1127 & 4.4316 & -5.1958 \\
\hline $\mathrm{C}$ & -6.3352 & 5.8245 & -5.716 \\
\hline $\mathrm{O}$ & -6.4467 & 6.6662 & -4.6003 \\
\hline $\mathrm{C}$ & -6.6528 & 8.0036 & -4.9593 \\
\hline $\mathrm{C}$ & -6.3405 & 8.8319 & -3.7391 \\
\hline $\mathrm{C}$ & -4.6352 & 2.7072 & -5.7711 \\
\hline $\mathrm{C}$ & -7.1244 & 17.1241 & -3.0932 \\
\hline $\mathrm{C}$ & -8.3733 & 17.0624 & -3.7153 \\
\hline $\mathrm{C}$ & -8.9372 & 18.2176 & -4.259 \\
\hline $\mathrm{C}$ & -8.2241 & 19.3861 & -4.1493 \\
\hline
\end{tabular}




\begin{tabular}{|c|c|c|c|}
\hline $\mathrm{C}$ & -6.9879 & 19.4422 & -3.5296 \\
\hline $\mathrm{C}$ & -6.4097 & 18.3125 & -2.9946 \\
\hline $\mathrm{C}$ & -8.5907 & 20.7396 & -4.6104 \\
\hline $\mathrm{N}$ & -7.5293 & 21.5684 & -4.1913 \\
\hline $\mathrm{C}$ & -6.5218 & 20.8324 & -3.5962 \\
\hline $\mathrm{O}$ & -5.4477 & 21.3063 & -3.2422 \\
\hline $\mathrm{O}$ & -9.5775 & 21.0868 & -5.2126 \\
\hline $\mathrm{C}$ & -7.4263 & 23.0125 & -4.3174 \\
\hline $\mathrm{C}$ & -2.1255 & -12.3029 & -2.2332 \\
\hline $\mathrm{C}$ & -3.2572 & -13.2449 & -2.3602 \\
\hline $\mathrm{C}$ & -4.3524 & -12.5454 & -2.8359 \\
\hline $\mathrm{C}$ & -3.9648 & -11.1321 & -3.0025 \\
\hline $\mathrm{C}$ & -3.3439 & -14.591 & -2.0863 \\
\hline $\mathrm{C}$ & -4.5637 & -15.2154 & -2.3191 \\
\hline $\mathrm{C}$ & -5.6642 & -14.5179 & -2.8222 \\
\hline $\mathrm{C}$ & -5.5622 & -13.1505 & -3.0773 \\
\hline $\mathrm{O}$ & -4.6202 & -10.2018 & -3.4205 \\
\hline $\mathrm{O}$ & -0.975 & -12.5284 & -1.9181 \\
\hline $\mathrm{O}$ & -1.0055 & -4.1409 & -1.7345 \\
\hline $\mathrm{C}$ & -0.7105 & -5.4825 & -2.1163 \\
\hline $\mathrm{C}$ & -1.7709 & -6.4458 & -1.6651 \\
\hline $\mathrm{O}$ & -1.3637 & -7.703 & -2.1358 \\
\hline $\mathrm{C}$ & -2.2902 & -8.7221 & -1.8677 \\
\hline $\mathrm{C}$ & -1.8427 & -9.8793 & -2.7165 \\
\hline $\mathrm{C}$ & -6.9771 & -15.2654 & -2.9799 \\
\hline $\mathrm{C}$ & -6.7724 & -16.6869 & -3.4739 \\
\hline $\mathrm{C}$ & -5.8602 & -16.8895 & -4.5124 \\
\hline $\mathrm{C}$ & -5.6485 & -18.1445 & -5.0713 \\
\hline $\mathrm{C}$ & -6.3731 & -19.1947 & -4.5577 \\
\hline $\mathrm{C}$ & -7.2881 & -18.9971 & -3.5383 \\
\hline $\mathrm{C}$ & -7.5175 & -17.7596 & -2.9841 \\
\hline $\mathrm{C}$ & -6.3823 & -20.6239 & -4.9342 \\
\hline $\mathrm{N}$ & -7.3287 & -21.2219 & -4.0759 \\
\hline $\mathrm{C}$ & -7.932 & -20.2839 & -3.2606 \\
\hline $\mathrm{O}$ & -8.8599 & -20.5336 & -2.4993 \\
\hline $\mathrm{O}$ & -5.7327 & -21.1827 & -5.7844 \\
\hline $\mathrm{C}$ & -7.7096 & -22.6212 & -3.9955 \\
\hline $\mathrm{C}$ & 0.5746 & -11.2076 & -4.5888 \\
\hline $\mathrm{C}$ & 1.5826 & -12.2102 & -4.1945 \\
\hline $\mathrm{C}$ & 2.8121 & -11.5825 & -4.1058 \\
\hline $\mathrm{C}$ & 2.621 & -10.1489 & -4.3905 \\
\hline $\mathrm{C}$ & 1.4456 & -13.5485 & -3.9051 \\
\hline $\mathrm{C}$ & 2.5951 & -14.2444 & -3.5543 \\
\hline $\mathrm{C}$ & 3.8454 & -13.6231 & -3.4931 \\
\hline
\end{tabular}




\begin{tabular}{|c|c|c|c|}
\hline $\mathrm{C}$ & 3.9581 & -12.2586 & -3.7578 \\
\hline $\mathrm{O}$ & 3.4348 & -9.2516 & -4.391 \\
\hline $\mathrm{O}$ & -0.6063 & -11.3747 & -4.8262 \\
\hline $\mathrm{O}$ & -1.0727 & -3.9343 & -6.2705 \\
\hline $\mathrm{C}$ & -1.4312 & -5.2931 & -6.0095 \\
\hline $\mathrm{C}$ & -0.3204 & -6.271 & -6.2793 \\
\hline $\mathrm{O}$ & -0.9349 & -7.5358 & -6.2572 \\
\hline $\mathrm{C}$ & -0.0356 & -8.6084 & -6.2275 \\
\hline $\mathrm{C}$ & 0.6634 & -8.7043 & -4.8826 \\
\hline $\mathrm{C}$ & 5.0283 & -14.4645 & -3.0443 \\
\hline $\mathrm{C}$ & 5.0302 & -15.8357 & -3.6974 \\
\hline $\mathrm{C}$ & 4.6849 & -15.9126 & -5.0483 \\
\hline $\mathrm{C}$ & 4.722 & -17.112 & -5.7492 \\
\hline $\mathrm{C}$ & 5.1252 & -18.2325 & -5.0617 \\
\hline $\mathrm{C}$ & 5.4796 & -18.1617 & -3.7257 \\
\hline $\mathrm{C}$ & 5.4427 & -16.9826 & -3.0178 \\
\hline $\mathrm{C}$ & 5.2662 & -19.6297 & -5.5188 \\
\hline $\mathrm{N}$ & 5.7485 & -20.3357 & -4.3966 \\
\hline $\mathrm{C}$ & 5.8468 & -19.5128 & -3.2906 \\
\hline $\mathrm{O}$ & 6.1549 & -19.9052 & -2.1705 \\
\hline $\mathrm{O}$ & 5.0275 & -20.0906 & -6.6089 \\
\hline $\mathrm{C}$ & 6.1366 & -21.7344 & -4.317 \\
\hline $\mathrm{C}$ & -1.9042 & -3.5038 & -2.4951 \\
\hline $\mathrm{O}$ & -2.5575 & -4.04 & -3.3699 \\
\hline $\mathrm{C}$ & -0.2206 & -3.3707 & -5.4098 \\
\hline $\mathrm{O}$ & 0.3801 & -3.981 & -4.5447 \\
\hline $\mathrm{C}$ & -9.1254 & 15.7437 & -3.6735 \\
\hline $\mathrm{C}$ & 7.2795 & 15.3179 & -3.2122 \\
\hline $\mathrm{N}$ & -6.6667 & 10.2141 & -3.9228 \\
\hline $\mathrm{N}$ & 5.2705 & 9.6231 & -3.3882 \\
\hline $\mathrm{N}$ & -2.6412 & -11.0555 & -2.5771 \\
\hline $\mathrm{N}$ & 1.2555 & -9.9936 & -4.6549 \\
\hline $\mathrm{C}$ & 4.7276 & 24.5381 & -4.4206 \\
\hline $\mathrm{C}$ & 5.4112 & 25.4639 & -5.1978 \\
\hline $\mathrm{C}$ & 5.0646 & 26.8049 & -5.1722 \\
\hline $\mathrm{C}$ & 4.029 & 27.2396 & -4.3593 \\
\hline $\mathrm{C}$ & 3.339 & 26.3237 & -3.5791 \\
\hline $\mathrm{C}$ & 3.6854 & 24.9827 & -3.6143 \\
\hline $\mathrm{C}$ & 5.0948 & 23.0915 & -4.4547 \\
\hline $\mathrm{C}$ & 6.8699 & 22.9699 & -2.6006 \\
\hline $\mathrm{O}$ & 7.5501 & 22.3118 & -1.8506 \\
\hline $\mathrm{O}$ & 7.2147 & 24.1788 & -3.0489 \\
\hline $\mathrm{C}$ & -6.4959 & 23.3482 & -5.488 \\
\hline $\mathrm{O}$ & -6.8723 & 23.8995 & -6.4912 \\
\hline
\end{tabular}




\begin{tabular}{|c|c|c|c|}
\hline $\mathrm{O}$ & -5.2356 & 22.9665 & -5.3077 \\
\hline $\mathrm{C}$ & -8.6331 & 25.1556 & -4.0318 \\
\hline $\mathrm{C}$ & -8.7985 & 25.5347 & -2.703 \\
\hline $\mathrm{C}$ & -8.6675 & 26.8602 & -2.3217 \\
\hline $\mathrm{C}$ & -8.368 & 27.8261 & -3.2706 \\
\hline $\mathrm{C}$ & -8.2017 & 27.4579 & -4.5969 \\
\hline $\mathrm{C}$ & -8.3308 & 26.131 & -4.9759 \\
\hline $\mathrm{C}$ & -8.7612 & 23.718 & -4.4184 \\
\hline $\mathrm{C}$ & -7.6581 & -15.2238 & -1.5999 \\
\hline $\mathrm{F}$ & -8.9368 & -15.6231 & -1.6473 \\
\hline $\mathrm{F}$ & -7.0105 & -16.0272 & -0.7445 \\
\hline $\mathrm{F}$ & -7.6432 & -13.994 & -1.0887 \\
\hline $\mathrm{C}$ & -7.909 & -14.5915 & -4.006 \\
\hline $\mathrm{F}$ & -8.412 & -13.4323 & -3.5621 \\
\hline $\mathrm{F}$ & -8.9386 & -15.3819 & -4.3099 \\
\hline $\mathrm{F}$ & -7.2406 & -14.3399 & -5.1393 \\
\hline $\mathrm{C}$ & -9.0335 & -22.8186 & -4.7423 \\
\hline $\mathrm{O}$ & -9.1302 & -23.4694 & -5.7517 \\
\hline $\mathrm{O}$ & -10.0692 & -22.1978 & -4.1868 \\
\hline $\mathrm{C}$ & -6.8915 & -24.9425 & -3.8686 \\
\hline $\mathrm{C}$ & -6.356 & -25.2743 & -2.6276 \\
\hline $\mathrm{C}$ & -6.6143 & -26.5066 & -2.0491 \\
\hline $\mathrm{C}$ & -7.4147 & -27.4262 & -2.7099 \\
\hline $\mathrm{C}$ & -7.9505 & -27.1058 & -3.9477 \\
\hline $\mathrm{C}$ & -7.692 & -25.8718 & -4.524 \\
\hline $\mathrm{C}$ & -6.6404 & -23.5891 & -4.4517 \\
\hline $\mathrm{C}$ & 4.9368 & -14.5518 & -1.5095 \\
\hline $\mathrm{F}$ & 3.93 & -15.3615 & -1.1529 \\
\hline $\mathrm{F}$ & 6.0591 & -15.0331 & -0.9547 \\
\hline $\mathrm{F}$ & 4.7067 & -13.3561 & -0.9719 \\
\hline $\mathrm{C}$ & 6.3758 & -13.8194 & -3.4171 \\
\hline $\mathrm{F}$ & 7.3883 & -14.6631 & -3.2124 \\
\hline $\mathrm{F}$ & 6.3843 & -13.4866 & -4.7152 \\
\hline $\mathrm{F}$ & 6.6267 & -12.7118 & -2.7082 \\
\hline $\mathrm{C}$ & 7.3794 & -23.5556 & -5.4355 \\
\hline $\mathrm{C}$ & 8.7602 & -23.4187 & -5.327 \\
\hline $\mathrm{C}$ & 9.5688 & -24.524 & -5.118 \\
\hline $\mathrm{C}$ & 9.0013 & -25.7855 & -5.0144 \\
\hline $\mathrm{C}$ & 7.6265 & -25.9314 & -5.118 \\
\hline $\mathrm{C}$ & 6.8193 & -24.8237 & -5.325 \\
\hline $\mathrm{C}$ & 6.5247 & -22.3473 & -5.6441 \\
\hline $\mathrm{C}$ & 5.0262 & -22.527 & -3.6169 \\
\hline $\mathrm{O}$ & 4.3684 & -23.3692 & -4.1738 \\
\hline $\mathrm{O}$ & 4.8421 & -22.1986 & -2.3427 \\
\hline
\end{tabular}




\begin{tabular}{|c|c|c|c|}
\hline $\mathrm{C}$ & -9.782 & 15.6842 & -2.28 \\
\hline $\mathrm{F}$ & -8.8544 & 15.4377 & -1.3451 \\
\hline $\mathrm{F}$ & -10.3678 & 16.8417 & -1.9724 \\
\hline $\mathrm{F}$ & -10.7158 & 14.7283 & -2.1926 \\
\hline $\mathrm{C}$ & -10.2345 & 15.677 & -4.7403 \\
\hline $\mathrm{F}$ & -11.252 & 16.5083 & -4.4747 \\
\hline $\mathrm{F}$ & -10.7399 & 14.4483 & -4.8369 \\
\hline $\mathrm{F}$ & -9.737 & 16.0086 & -5.939 \\
\hline $\mathrm{C}$ & 8.0584 & 15.3268 & -4.5424 \\
\hline $\mathrm{F}$ & 8.5623 & 14.1251 & -4.8237 \\
\hline $\mathrm{F}$ & 7.2406 & 15.6671 & -5.5476 \\
\hline $\mathrm{F}$ & 9.0811 & 16.1927 & -4.531 \\
\hline $\mathrm{C}$ & 8.2937 & 15.2436 & -2.0522 \\
\hline $\mathrm{F}$ & 7.6683 & 14.9009 & -0.918 \\
\hline $\mathrm{F}$ & 9.2631 & 14.3431 & -2.2711 \\
\hline $\mathrm{F}$ & 8.8867 & 16.4191 & -1.8509 \\
\hline $\mathrm{H}$ & -1.9188 & -1.7469 & -6.7728 \\
\hline $\mathrm{H}$ & 0.1039 & 1.9294 & -5.8374 \\
\hline $\mathrm{H}$ & 1.6685 & -1.8175 & -4.399 \\
\hline $\mathrm{H}$ & -3.7753 & -1.8355 & -3.349 \\
\hline $\mathrm{H}$ & -0.174 & -2.0367 & -1.0039 \\
\hline $\mathrm{H}$ & -2.1597 & 1.7341 & -1.5591 \\
\hline $\mathrm{H}$ & 7.8538 & 12.7013 & -2.4132 \\
\hline $\mathrm{H}$ & 4.7907 & 15.1718 & -4.2006 \\
\hline $\mathrm{H}$ & 3.3704 & 13.152 & -4.5957 \\
\hline $\mathrm{H}$ & 4.3115 & 3.6321 & -2.8112 \\
\hline $\mathrm{H}$ & 5.414 & 3.8132 & -1.4041 \\
\hline $\mathrm{H}$ & 4.1359 & 5.7547 & -0.5853 \\
\hline $\mathrm{H}$ & 2.87 & 5.4829 & -1.8203 \\
\hline $\mathrm{H}$ & 4.9048 & 7.873 & -1.4059 \\
\hline $\mathrm{H}$ & 3.4224 & 7.7842 & -2.4202 \\
\hline $\mathrm{H}$ & 4.7697 & 7.9376 & -4.4727 \\
\hline $\mathrm{H}$ & 6.2858 & 7.8487 & -3.5069 \\
\hline $\mathrm{H}$ & 5.2464 & 15.6929 & -1.5235 \\
\hline $\mathrm{H}$ & 7.6573 & 17.8442 & -4.3992 \\
\hline $\mathrm{H}$ & 4.062 & 17.8082 & -0.9157 \\
\hline $\mathrm{H}$ & -9.2038 & 13.1744 & -2.5317 \\
\hline $\mathrm{H}$ & -7.1122 & 15.6217 & -5.4205 \\
\hline $\mathrm{H}$ & -5.6846 & 13.6736 & -6.0637 \\
\hline $\mathrm{H}$ & -5.5392 & 4.4843 & -4.2566 \\
\hline $\mathrm{H}$ & -7.0459 & 3.8855 & -4.9872 \\
\hline $\mathrm{H}$ & -7.2384 & 5.8904 & -6.3565 \\
\hline $\mathrm{H}$ & -5.4627 & 6.114 & -6.3381 \\
\hline $\mathrm{H}$ & -7.7009 & 8.177 & -5.2851 \\
\hline
\end{tabular}


$\mathrm{H}$

$\mathrm{H}$

$\mathrm{H}$

$\mathrm{H}$

$\mathrm{H}$

$\mathrm{H}$

$\mathrm{H}$

$\mathrm{H}$

$\mathrm{H}$

$\mathrm{H}$

$\mathrm{H}$

$\mathrm{H}$

$\mathrm{H}$

$\mathrm{H}$

$\mathrm{H}$

$\mathrm{H}$

$\mathrm{H}$

$\mathrm{H}$

$\mathrm{H}$

$\mathrm{H}$

$\mathrm{H}$

$\mathrm{H}$

$\mathrm{H}$

$\mathrm{H}$

$\mathrm{H}$

$\mathrm{H}$

$\mathrm{H}$

$\mathrm{H}$

$\mathrm{H}$

$\mathrm{H}$

$\mathrm{H}$

$\mathrm{H}$

$\mathrm{H}$

$\mathrm{H}$

$\mathrm{H}$

$\mathrm{H}$

$\mathrm{H}$

$\mathrm{H}$

$\mathrm{H}$

$\mathrm{H}$

$\mathrm{H}$

$\mathrm{H}$

$\mathrm{H}$

$\mathrm{H}$

$\begin{array}{cll}-5.982 & 8.2964 & -5.7927 \\ -5.2699 & 8.7348 & -3.4949 \\ -6.9356 & 8.4786 & -2.8811 \\ -6.7039 & 16.2066 & -2.6704 \\ -9.9155 & 18.2284 & -4.745 \\ -5.4336 & 18.3537 & -2.5045 \\ -2.4856 & -15.1428 & -1.6939 \\ -4.6697 & -16.2827 & -2.1029 \\ -6.4 & -12.5533 & -3.4454 \\ 0.2539 & -5.7165 & -1.6451 \\ -0.5882 & -5.5268 & -3.2107 \\ -2.7506 & -6.1629 & -2.0993 \\ -1.8614 & -6.4435 & -0.559 \\ -3.3146 & -8.411 & -2.1544 \\ -2.2921 & -8.9883 & -0.7899 \\ -0.8126 & -10.1661 & -2.4472 \\ -1.8538 & -9.5715 & -3.7755 \\ -5.2984 & -16.0305 & -4.8914 \\ -4.9391 & -18.2977 & -5.8888 \\ -8.2672 & -17.6465 & -2.198 \\ 0.4644 & -14.0294 & -3.9299 \\ 2.5261 & -15.3099 & -3.3151 \\ 4.9041 & -11.7164 & -3.6891 \\ -2.269 & -5.5059 & -6.6882 \\ -1.7891 & -5.3676 & -4.9687 \\ 0.4637 & -6.1724 & -5.5057 \\ 0.1419 & -6.0724 & -7.2698 \\ 0.7083 & -8.533 & -7.0481 \\ -0.6384 & -9.5169 & -6.3841 \\ -0.0706 & -8.4747 & -4.0867 \\ 1.4946 & -7.9856 & -4.7894 \\ 4.3719 & -14.9988 & -5.5619 \\ 4.4469 & -17.1701 & -6.8056 \\ 5.7383 & -16.9685 & -1.9661 \\ 6.2414 & 25.1202 & -5.8236 \\ 5.6128 & 27.5208 & -5.7911 \\ 3.7571 & 28.2983 & -4.3344 \\ 2.516 & 26.657 & -2.9411 \\ 3.1274 & 24.2623 & -3.004 \\ 5.9011 & 22.9079 & -5.1833 \\ 4.2237 & 22.4986 & -4.7857 \\ 8.0881 & 24.3736 & -2.6415 \\ -5.1415 & 22.4868 & -4.4294 \\ -9.0484 & 24.7727 & -1.9555\end{array}$




$\begin{array}{llll}\mathrm{H} & -8.809 & 27.1437 & -1.2751 \\ \mathrm{H} & -8.2703 & 28.8742 & -2.9745 \\ \mathrm{H} & -7.9712 & 28.2159 & -5.3507 \\ \mathrm{H} & -8.1834 & 25.8262 & -6.0168 \\ \mathrm{H} & -9.1427 & 23.6142 & -5.4453 \\ \mathrm{H} & -9.4804 & 23.2182 & -3.7497 \\ \mathrm{H} & -9.7685 & -21.6756 & -3.3829 \\ \mathrm{H} & -5.7141 & -24.5513 & -2.1107 \\ \mathrm{H} & -6.1802 & -26.754 & -1.0764 \\ \mathrm{H} & -7.6183 & -28.401 & -2.2583 \\ \mathrm{H} & -8.5812 & -27.8274 & -4.4744 \\ \mathrm{H} & -8.1301 & -25.6004 & -5.4896 \\ \mathrm{H} & -6.6325 & -23.6219 & -5.5517 \\ \mathrm{H} & -5.6561 & -23.2168 & -4.1246 \\ \mathrm{H} & 9.2093 & -22.4235 & -5.4267 \\ \mathrm{H} & 10.6529 & -24.4015 & -5.0448 \\ \mathrm{H} & 9.6372 & -26.6606 & -4.8547 \\ \mathrm{H} & 7.1735 & -26.9232 & -5.034 \\ \mathrm{H} & 5.7309 & -24.9244 & -5.3844 \\ \mathrm{H} & 5.6106 & -22.6004 & -6.2018 \\ \mathrm{H} & 7.0764 & -21.6006 & -6.2375 \\ \mathrm{H} & 5.4555 & -21.4432 & -2.0881 \\ \mathrm{H} & 7.0171 & -21.7503 & -3.6449 \\ \mathrm{H} & -6.9144 & 23.3467 & -3.3935 \\ \mathrm{H} & 4.7767 & 22.8369 & -2.3312 \\ \mathrm{H} & -7.9169 & -22.799 & -2.9219\end{array}$




\section{Copies of ${ }^{1} \mathrm{H}$ and ${ }^{13} \mathrm{C}$ NMR spectra}

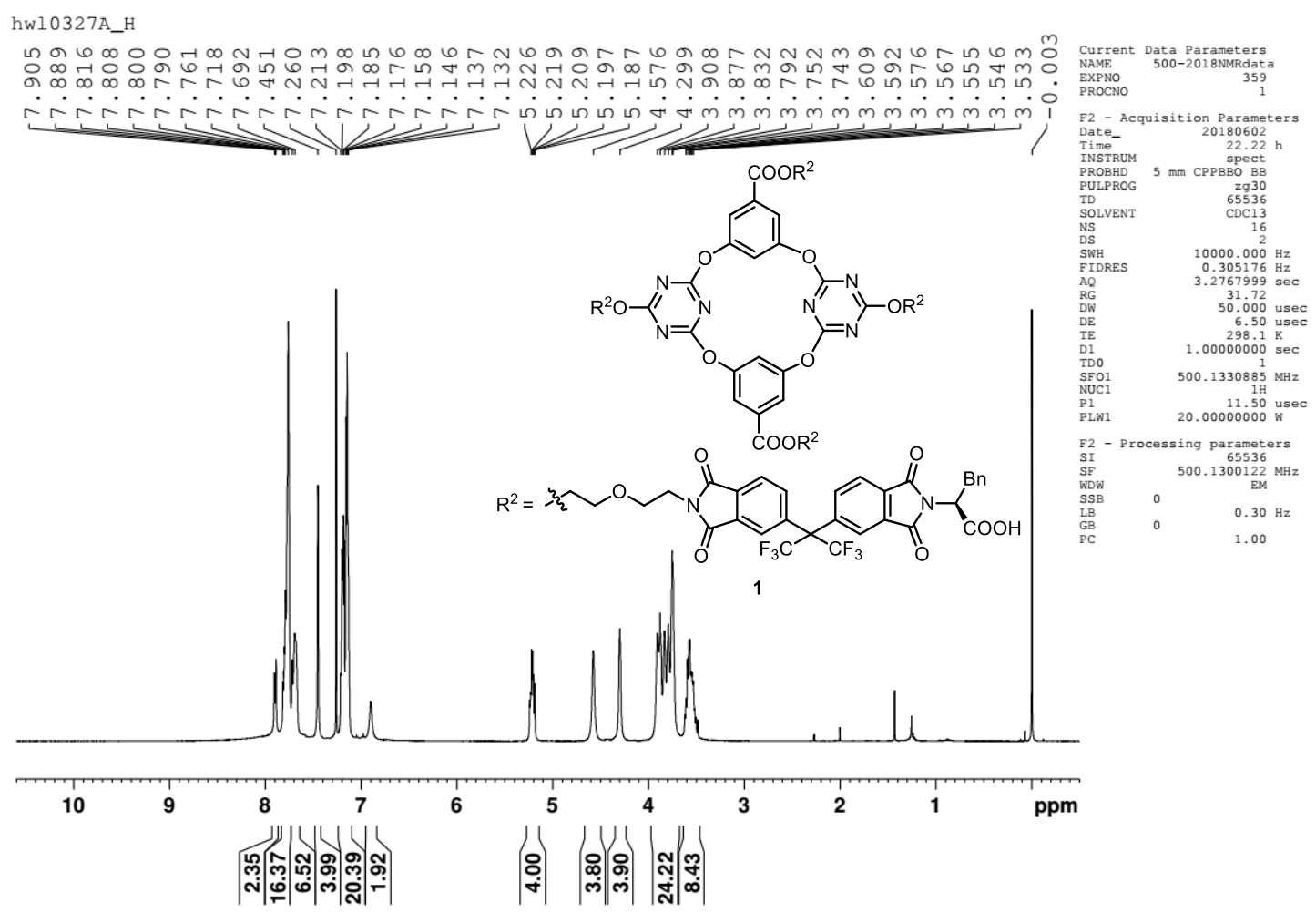

Figure S55. ${ }^{1}$ H NMR spectrum of 1 .

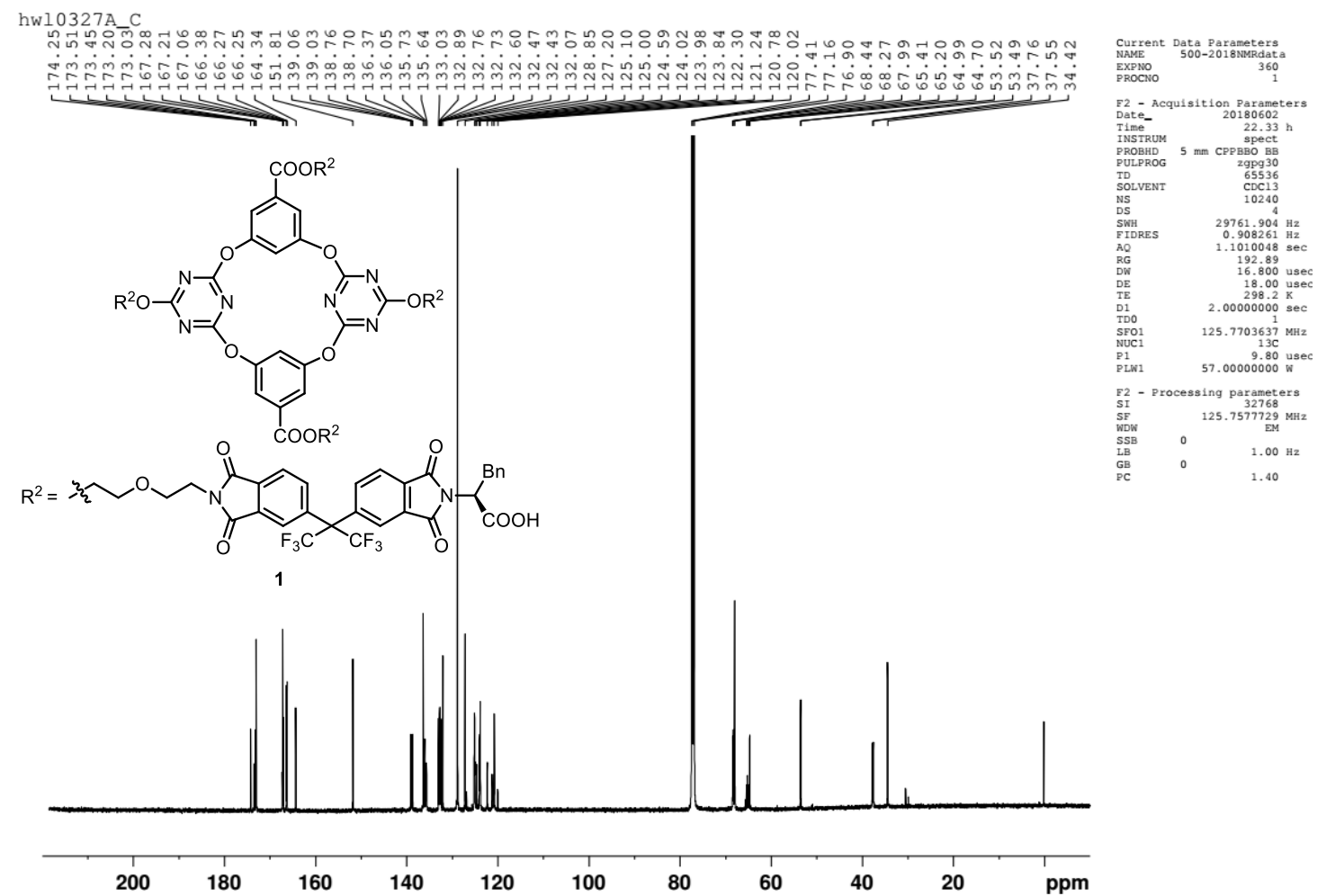

Figure S56. ${ }^{13} \mathrm{C}$ NMR spectrum of $\mathbf{1}$. 


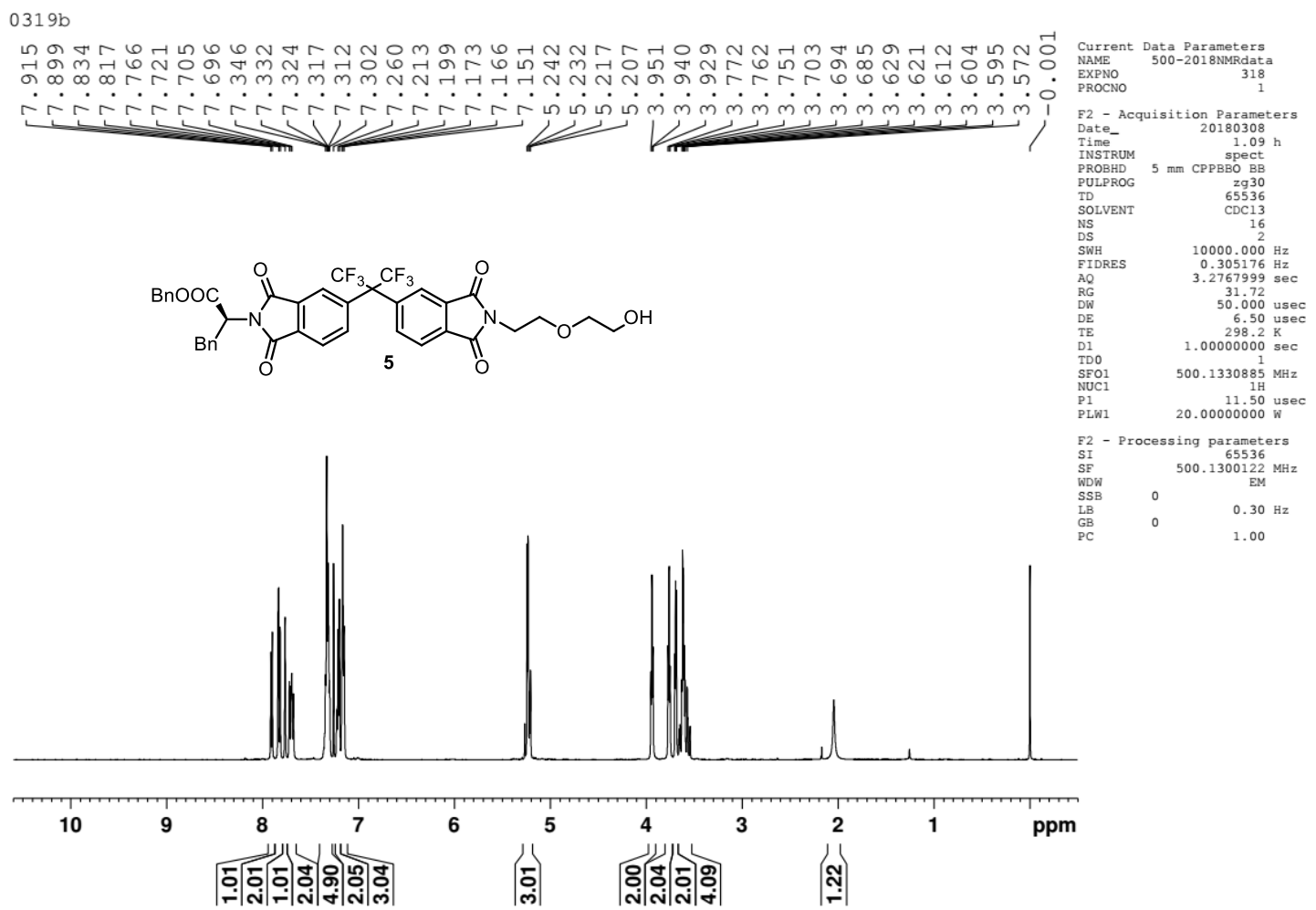

Figure S57. ${ }^{1}$ H NMR spectrum of 5.

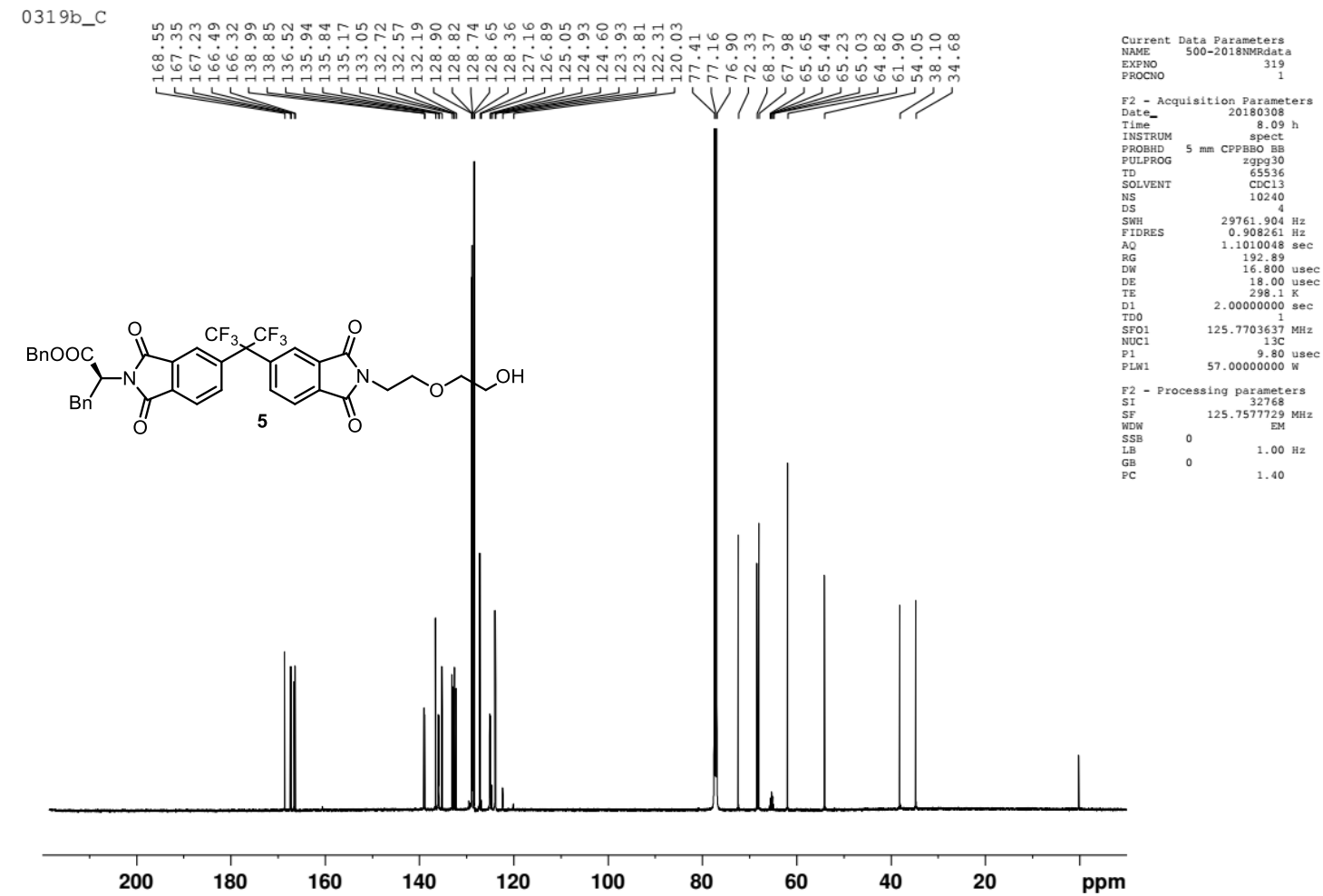

Figure S58. ${ }^{13} \mathrm{C}$ NMR spectrum of 5 . 


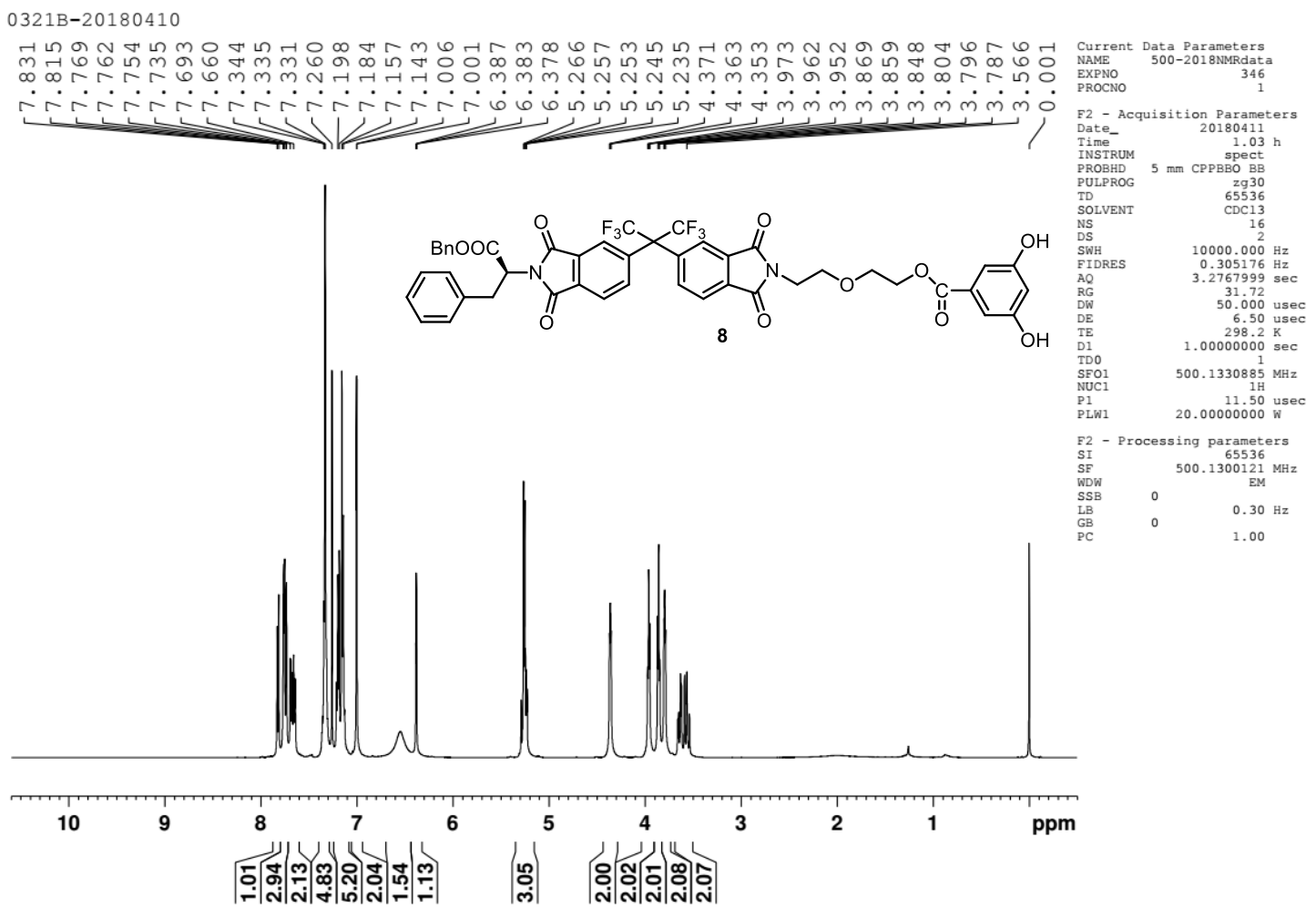

Figure S59. ${ }^{1}$ H NMR spectrum of 8 .

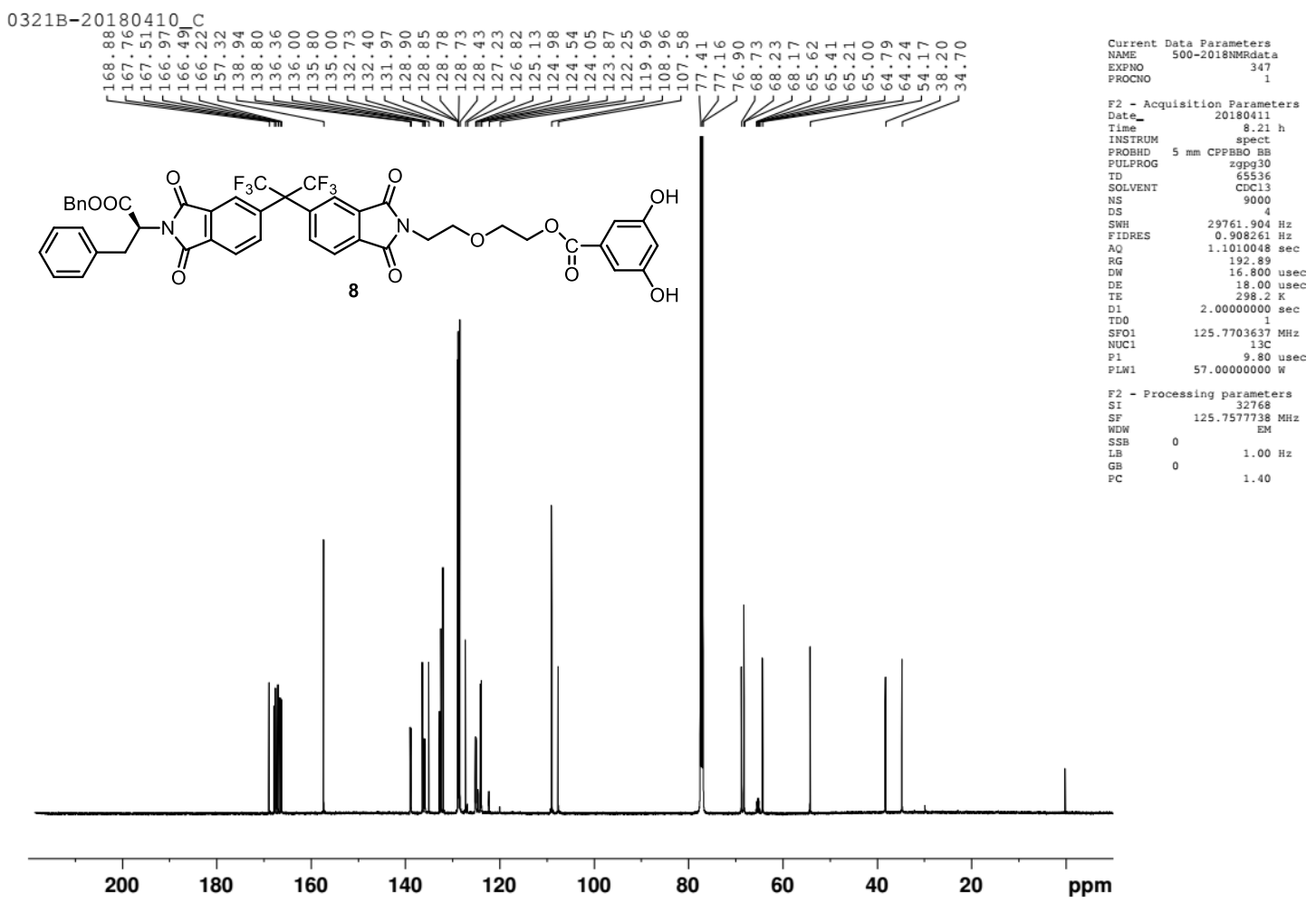

Figure S60. ${ }^{13} \mathrm{C}$ NMR spectrum of 8 . 


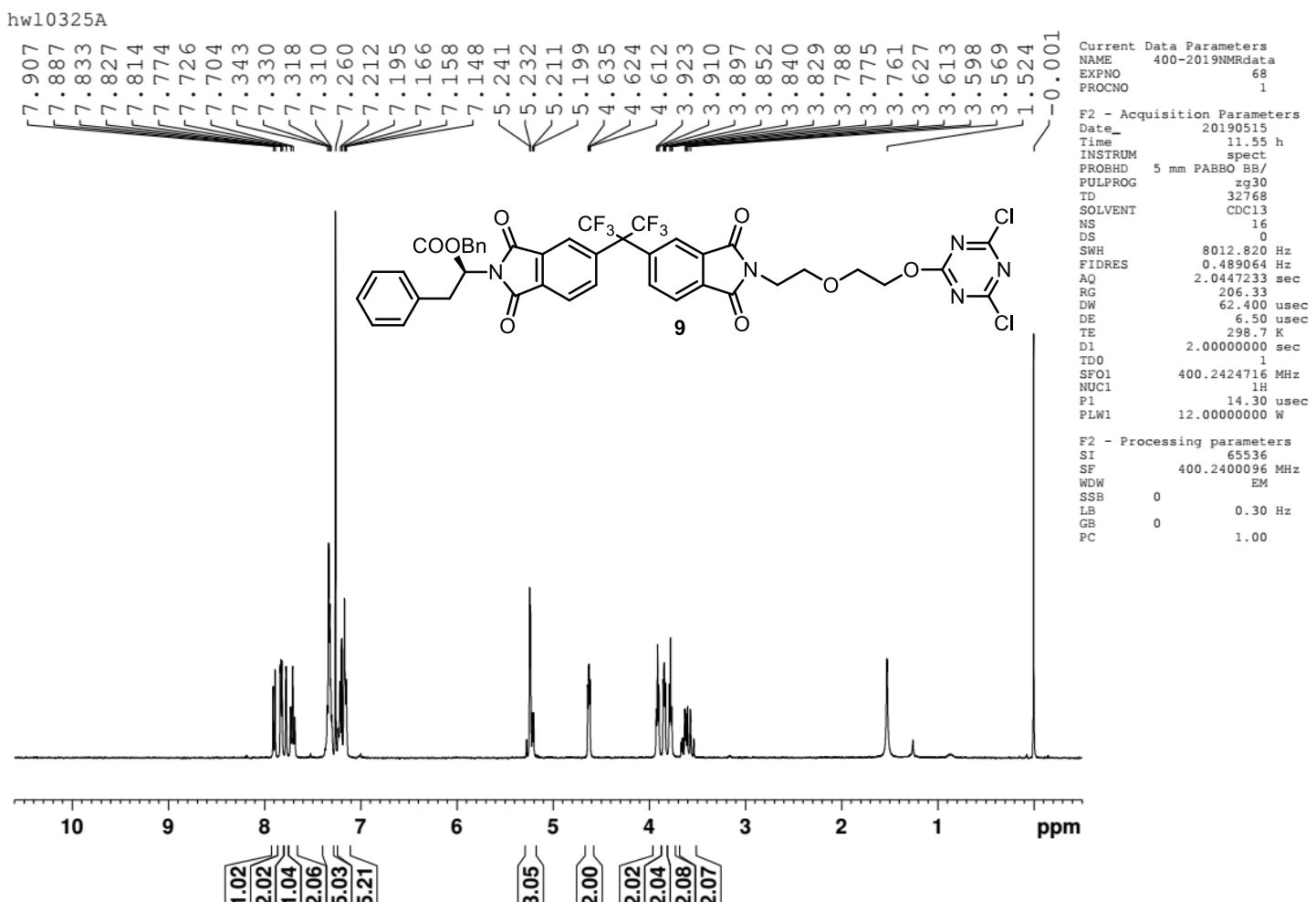

Figure S61. ${ }^{1}$ H NMR spectrum of 9 .

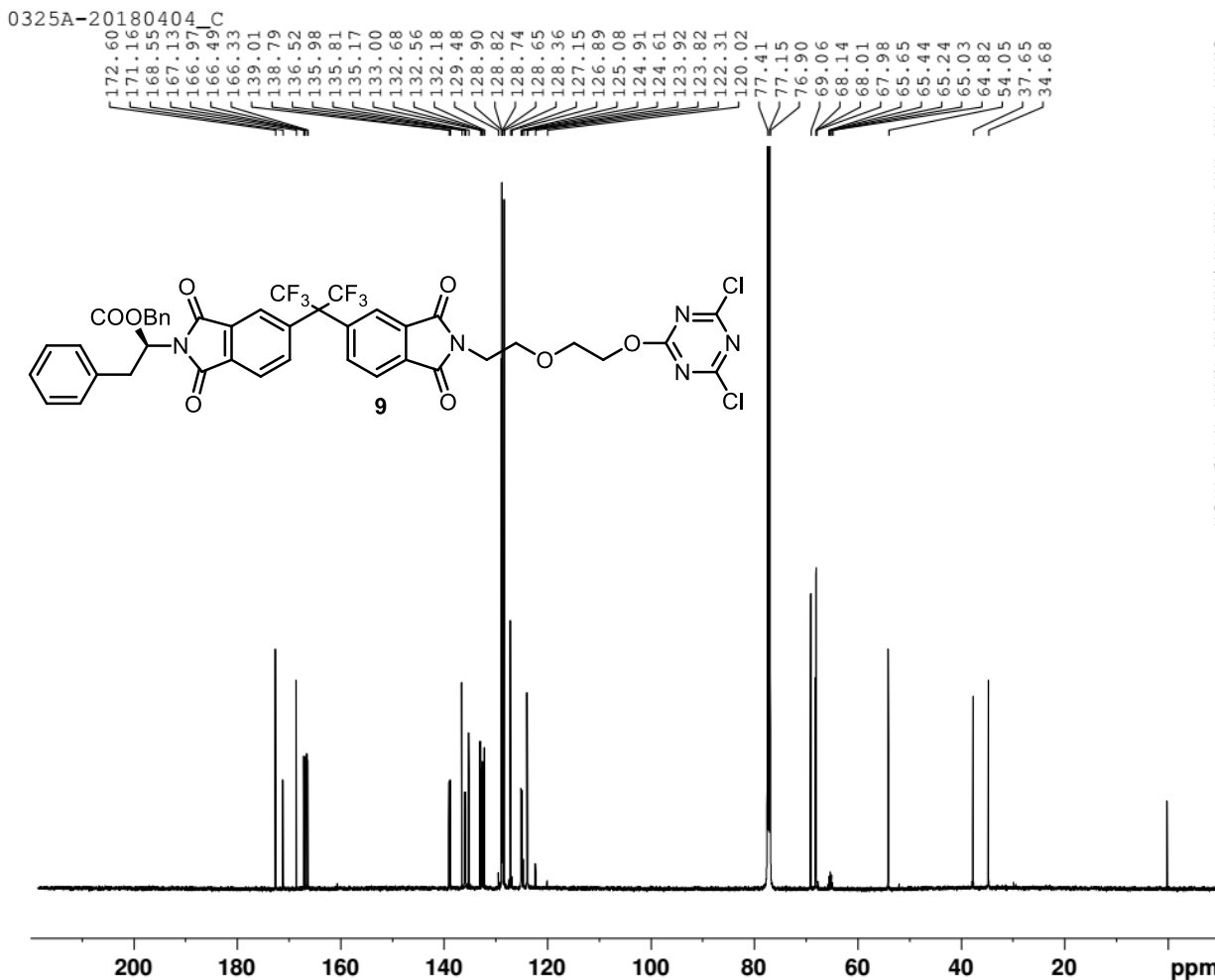

Figure S62. ${ }^{13} \mathrm{C}$ NMR spectrum of 9 . 


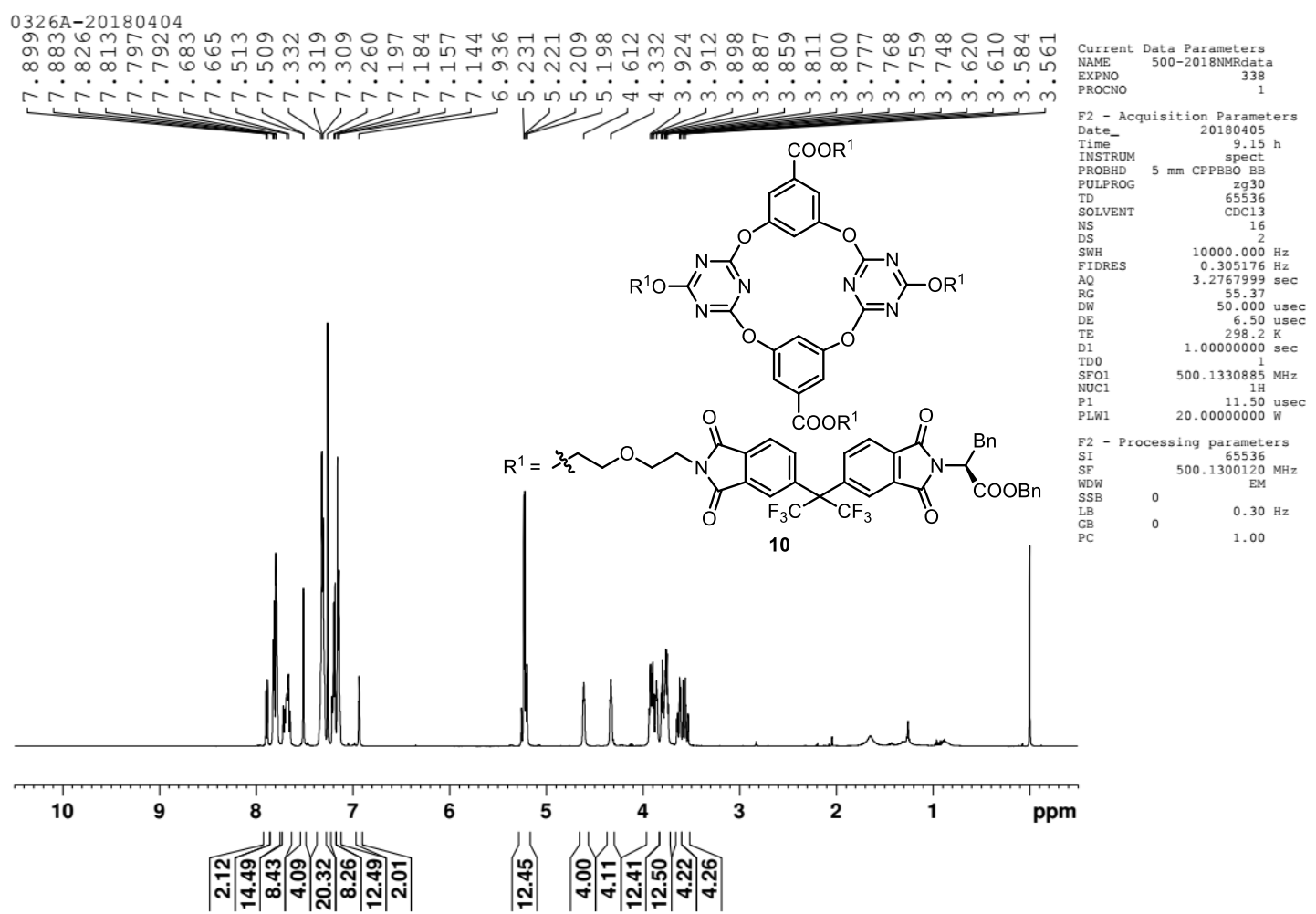

Figure S63. ${ }^{1}$ H NMR spectrum of $\mathbf{1 0}$.

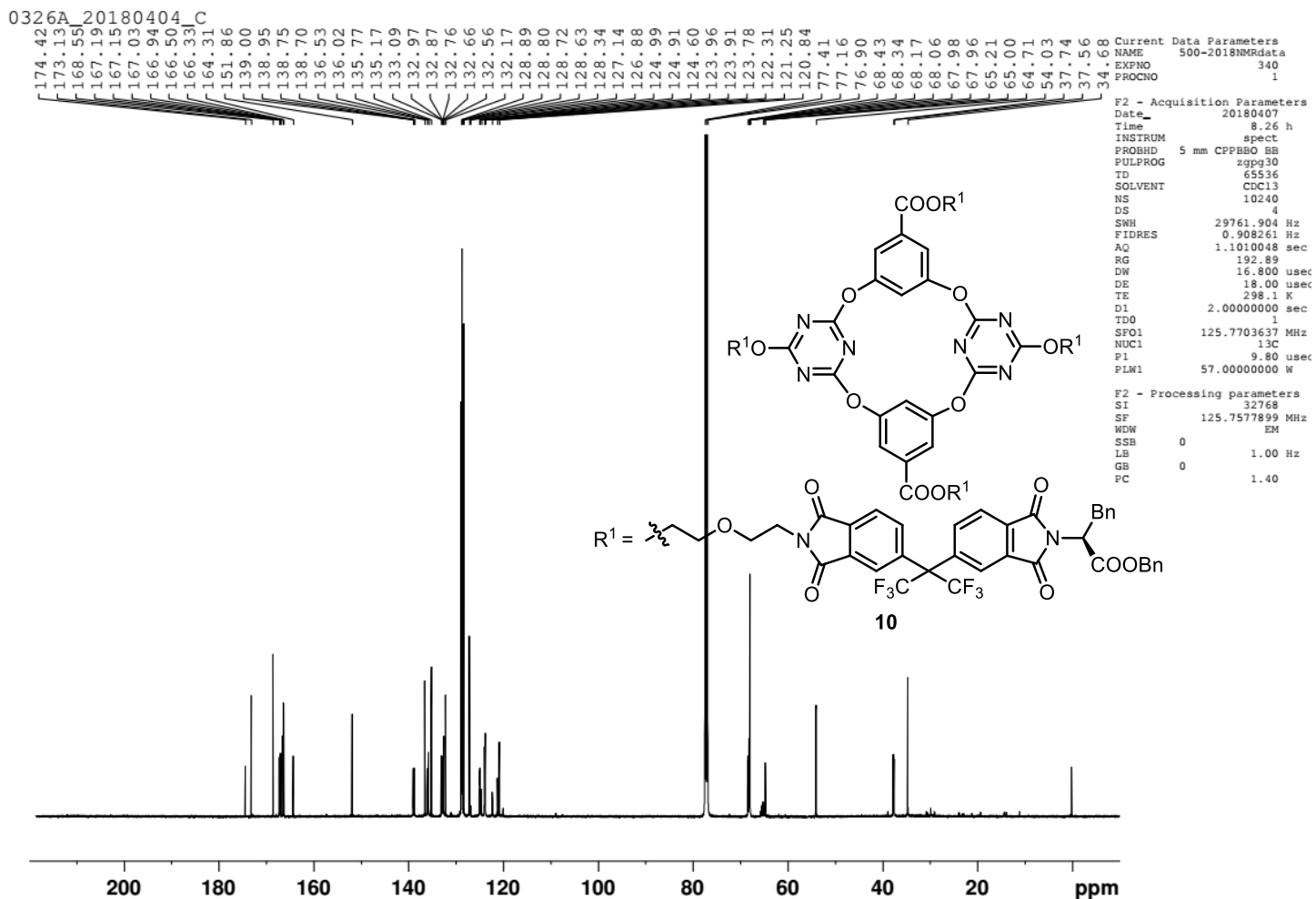

Figure S64. ${ }^{13} \mathrm{C}$ NMR spectrum of $\mathbf{1 0}$. 


\section{References}

[S1] Boyle, T. P.; Bremner, J. B.; Brkic, Z.; Coates, J. A. V.; Dalton, N. K.; Deadman, J.; Keller, P. A.; Morgan, J.; Pyne, S. G.; Rhodes, D. I.; Robertson, M. J. Preparation of Biaryl-Based Peptides for the Treatment of Infection, AU: WO2006074501 (A1). 2006-07-20.

[S2] Hou, B.-Y.; Wang, D.-X.; Yang, H.-B.; Zheng, Q.-Y.; Wang, M.-X. Synthesis and Structure of Upper-Rim 1,3-Alternate Tetraoxacalix[2]arene[2]triazine Azacrowns and Change of Cavity in Response to Fluoride Anion, J. Org. Chem. 2007, $72,5218-5226$.

[S3] Huang, W.-L.; Wang, X.-D.; Li, S.; Zhang, R.; Ao, Y.-F.; Tang, J.; Wang, Q.-Q.;

Wang, D.-X. Anion Transporters Based on Noncovalent Balance Including Anion- $\pi$, Hydrogen, and Halogen Bonding, J. Org. Chem. 2019, 84, 8859-8869.

[S4] Wang, X.-D.; Li, S.; Ao, Y.-F.; Wang, Q.-Q.; Huang, Z.-T.; Wang, D.-X. Oxacalix[2]arene[2]triazine Based Ion-Pair Transporters, Org. Biomol. Chem. 2016, $14,330-334$.

[S5] Gorteau, V.; Bollot, G.; Mareda, J.; Matile, S. Rigid-Rod Anion- $\pi$ Slides for Multiion Hopping Across Lipid Bilayers, Org. Biomol. Chem. 2007, 5, 3000-3012.

[S6] Chui, J. K. W.; Fyles, T. M. Ionic Conductance of Synthetic Channels: Analysis, Lessons, and Recommendations, Chem. Soc. Rev. 2012, 41, 148-175. 